UNITED STATES

DEPARTMENT OF THE INTERIOR

GEOLOGICAL SURVEY

CHANGES IN SURFACE-WATER HYDROLOGY, PLATTE RIVER BASIN IN COLORADO, WYOMING, AND NEBRASKA UPSTREAM FROM DUNCAN, NEBRASKA

By J. E. Kircher and M. R. Karlinger

OPEN-FILE REPORT $81-818$

Denver, Colorado

1981 


\section{UNITED STATES DEPARTMENT OF THE INTERIOR \\ JAMES G. WATT, Secretary \\ GEOLOGICAL SURVEY}

Doyle G. Frederick, Acting Director

For additional information write to:

U.S. Geological Survey

Water Resources Division

Mail Stop 413, Box 25046

Denver Federal Center

Denver, Colorado 80225

For purchase write to:

Open File Services Section

U.S. Geological Survey

Box 25425

Denver Federal Center

Denver, Colorado 80225

(303) 234-5888; FTS 234-5888 


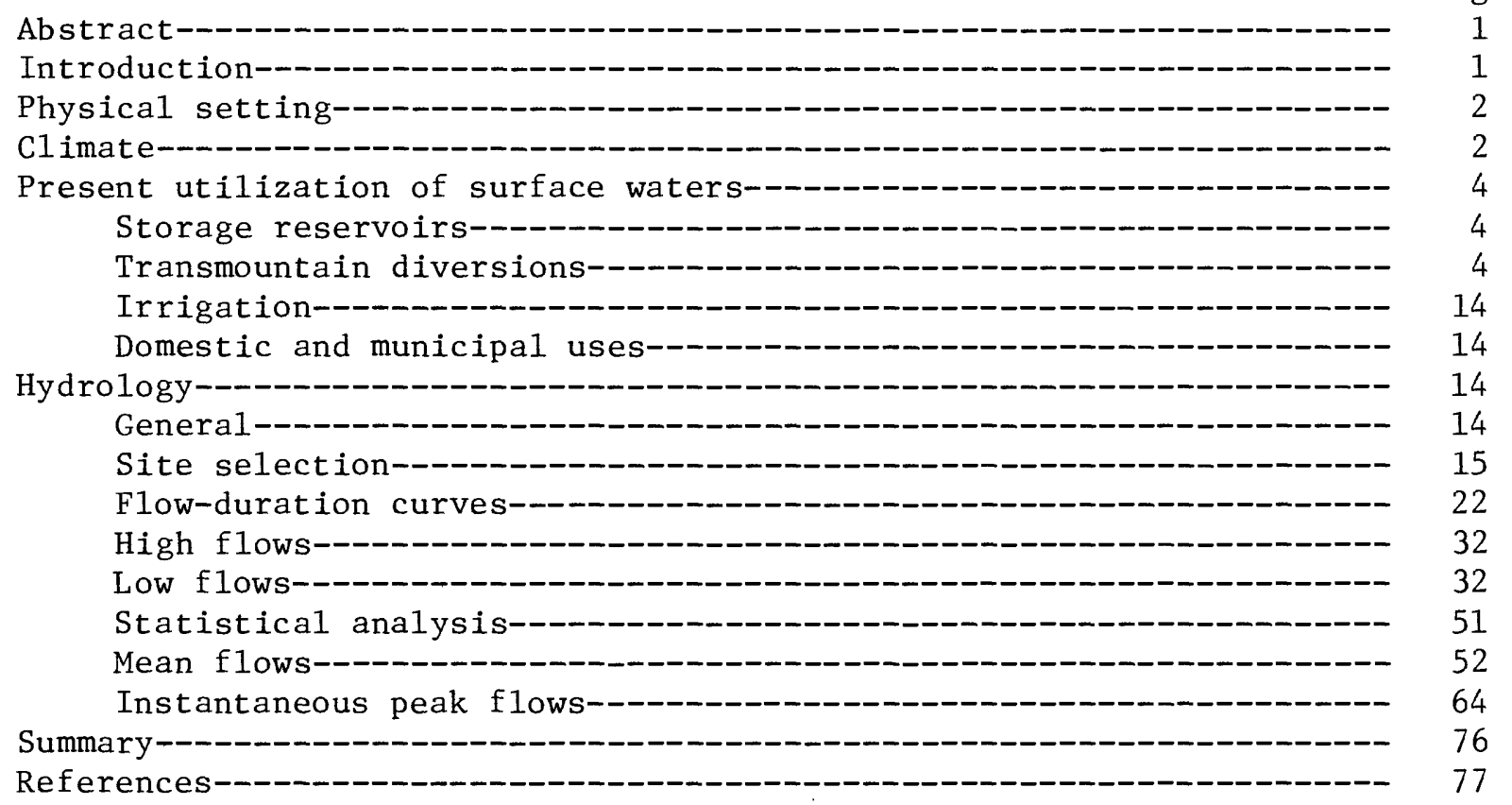

\section{ILLUSTRATIONS}

Figure 1. Map of the Platte River basin showing location of

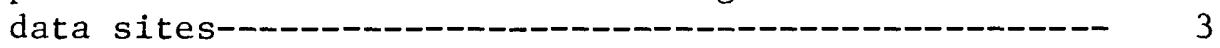

2-5. Graphs showing annual precipitation at:

2. Julesburg, Colorado (1888-1978)--_-_-_-_-_- 6

3. North Platte, Nebraska (1875-1978)-_-_-_-_-_ 7

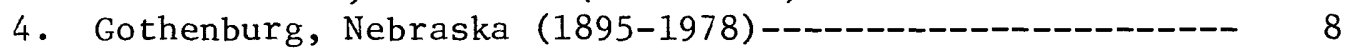

5. Grand Island, Nebraska (1890-1978)--_-_-_-_-_-_--- 9

6-9. Graphs showing change in channel area and island area near:

6. Cozad, Nebraska-_-_-_-_-_- 16

7. Overton, Nebraska--_-_-_-_-_-_-_-_-_-_-_-_-_-_-_-- 17

8. Grand Island, Nebraska--_--_-_-_-_-_-_--_-_-_-_--- 18

9. Duncan, Nebraska-_-_-__-_-_-_-_-_-_-_-_-_ 19

10. Change in channel width at four sites along the Platte

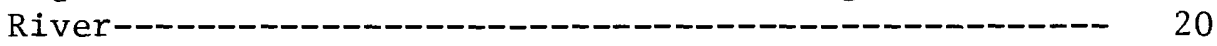

11-19. Graphs showing selected flow-duration curves at:

11. Station 06693000, North P1atte River at North P1atte, Nebraska (water years 1931-79)-_-_-_-_- 23

12. Station 06754000 , South Platte River near Kersey, Colorado (water years $1902,1903,1906-12,1915-79$ )-- 24

13. Station 06764000 , South Platte River at Julesburg, Colorado (water years 1903-06, 1909-12, 1914-21,

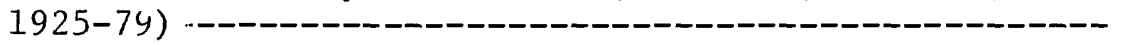




\section{ILLUSTRATIONS--Continued}

Figure 14. Station 06765500, South Platte River at North Platte, Nebraska (water years 1932-79)---------------------- 26

15. Station 06766500, Platte River near Cozad, Nebraska

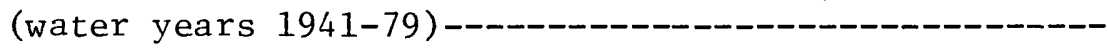

16. Station 06768000 , Platte River near Overton, Nebraska

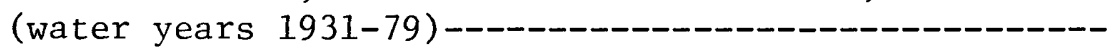

17. Station 06770000 , Platte River near Odessa, Nebraska (water years 1940-79)

18. Station 06770500, Platte River near Grand Island, Nebraska (water years 1935-79)

19. Station 06774000 , Platte River near Duncan, Nebraska (water years 1930-79)--------------------------

20-28. Graphs showing the mean 1-, 3-, 7-, 15-, and 30-day high flows at:

20. Station 06693000, North Platte River at North Platte, Nebraska (water years 1931-79)--_-_-_-_-_-_-_-_-_--

21. Station 06754000 , South Platte River near Kersey, Colorado (water years $1902,1903,1906-12,1915-79$ )-tation 06764000, South Platte River at Julesburg, Colorado (water years 1903-06, 1909-12, 1914-21, 1925-79)--

23. Station 06765500 , South Platte River at North Platte, Nebraska (water years 1932-79)

24. Station 06766500, Platte River near Cozad, Nebraska
(water years 1941-79)

25. Station 06768000 , Platte River near Overton, Nebraska (water years 1931-79)----------------------------

26. Station 06770000 , Platte River near Odessa, Nebraska (water years 1940-79)--_-_-_-_-

27. Station 06770500 , Platte River near Grand Island, Nebraska (water years 1935-79)---_--_-_---_----- 40

28. Station 06774000, Platte River near Duncan, Nebraska (water years 1930-79)---_-_--_---_-_---_--- 41

29-37. Graphs showing the mean 1-, 3-, 7-, 14-, and 30-day low flows at:

29. Station 06693000 , North Platte River at North Platte, Nebraska (water years 1931-79)--_-_-_-_-_--_---- 42

30. Station 06754000 , South Platte River near Kersey, Colorado (water years $1902,1903,1906-12,1915-79$ )-- 43

31. Station 06764000 , South Platte River at Julesburg, Colorado (water years 1903-06, 1909-12, 1914-21, 1925-79)---_- 44

32. Station 06765500 , South Platte River at North Platte, Nebraska (water years 1932-79)-------------------- 45

33. Station 06766500, Platte River near Cozad, Nebraska (water years 1941-79) 


\section{ILLUSTRATIONS--Continued}

Figure 34. Station 06768000 , Platte River near Overton, Nebraska

- (water years 1931-79)-_- 47

35. Station 06770000 , Platte River near Odessa, Nebraska (water years 1940-79)-_._. 48

36. Station 06770500 , Platte River near Grand Island, Nebraska (water years 1935-79)-_____-_ 49

37. Station 06774000 , Platte River near Duncan, Nebraska (water years 1930-79)-_-_- 50

38-43. Graphs showing annual mean discharges at:

38. Station 06693000 , North Platte River at North Platte, Nebraska (water years 1895-1979) - 54

39. Station 06754000 , South Platte River near Kersey, Colorado (water years 1902, 1903, 1906-12, 1915-79)--

40. Station 06764000 , South Platte River at Julesburg, Colorado (water years 1903-06, 1909-12, 1914-21, 1925-79) -

41. Station 06765500, South Platte River at North Platte, Nebraska (water years 1918-79)-_-_-_-_-

42. Station 06768000 , Platte River near Overton, Nebraska (water years 1915-79)----_-_-

43. Station 06770500, Platte River near Grand Island, Nebraska (water years 1934-79)--

44-47. Graphs showing monthly mean discharges for April through September at:

44. Station 06693000 , North Platte River at North Platte, Nebraska (water years 1931-78)-_-_-_._-

45. Station 06765500, South Platte River at North Platte, Nebraska (water years 1932-78) -

46. Station 06768000 , Platte River near Overton, Nebraska (water years 1931-78)

47. Station 06770500 , Platte River near Grand Island, Nebraska (water years 1935-78)-_-_-_-_-_-

48-53. Graphs showing annual instantaneous peak discharges at:

48. Station 06693000, North Platte River at North Platte, Nebraska (water years 1895-1979)-_...-

49. Station 06754000 , South Platte River near Kersey, Colorado (water years 1902, 1903, 1905-12, 1914-79)--

50. Station 06764000 , South Platte River at Julesburg, Colorado (water years 1902-06, 1909-12, 1914-15, 1917-18, 1920-24, 1926-79)-_.

51. Station 06765500, South Platte River at North Platte, Nebraska (water years 1897, 1914-15, 1917, 1921-79)--

52. Station 06768000 , Platte River near Overton, Nebraska (water years 1915-17, 1919-23, 1926-79)-_-_..-_...-.

53. Station 06770500, Platte River near Grand Island, Nebraska (water years 1934-79)-_._-_._._-_._-

54. Comparison of instantaneous peak flows on the South Platte River at North Platte, Nebraska, and the Platte River near Overton, Nebraska-_._._._._._....... 
Table 1. Mean annual precipitation at selected sites-_-_-_-_-_-_ 5

2. Surface-water areas as of 1962 and evaporation from reservoirs, lakes, streams, and canals_... 10

3. Reservoirs with capacities greater than 0.6 cubic hectometer-_. 11

4. Streamflow characteristics of primary data sites-_._- 21

5. Summary of regression and covariance analysis for the logarithms of annual mean flows-_.... 53

6. Summary of regression and covariance analysis for the logarithms of annual peak flows- 71

7. Summary of regression results relating the logarithms of mean annual and peak flows of the South Platte River and North Platte River to the logarithms of mean annual and peak flows of the Platte River-_- 74

8. Summary of beta coefficients relating the logarithms of mean annual and peak flows of the North Platte River and South Platte River to the logarithms of mean annual and peak flows of the Platte River- 


\title{
CHANGES IN SURFACE-WATER HYDROLOGY, PLATTE RIVER BASIN IN COLORADO, WYOMING, AND NEBRASKA UPSTREAM FROM DUNCAN, NEBRASKA
}

\author{
By J. E. Kircher and M. R. Karlinger
}

\begin{abstract}
The North Platte and Platte Rivers in western and central Nebraska have undergone significant changes in surface-water hydrology since the latter part of the 19th century. The South Platte River in Colorado and Nebraska has undergone much less change during the same period. This report presents an analysis of the changes in surface-water resources in the Platte River basin in Colorado, Wyoming, and Nebraska upstream from Duncan, Nebraska, an area of 157,700 square kilometers.

Nine stream-gaging stations in the basin were selected for analysis of streamflow changes. Flow-duration curves, 1-,3-,7-, 14-, and 30-day mean low flows, and 1-, 3-, 7-, 15-, and 30-day mean high flows were determined for all stations. Beginning about 1950, flow-duration curves for all stations, except the South Platte River near Kersey, Colorado, show a change with time of the low flow segment of the distribution curve in a downstream direction. The analyses indicate that high flows have been relatively unaffected by water development in the Platte River basin. Low flows in the North Platte River increased following the closure of Kingsley Dam during 1941. Low flows in the South Platte River at Julesburg, Colorado, increased, beginning about 1920, and at North Platte, Nebraska, about 1932. Statistical analyses of data from six selected sites were performed to determine: (1) The significance of major water developments that may have produced abrupt changes in the time series of streamflow statistics, and (2) significance of water developments that caused a more gradual change or time trend in the streamflow statistics.
\end{abstract}

\section{INTRODUCTION}

The Platte River in Nebraska is one of the most important rivers of the Great Plains, not only because of the agriculture within its basin, but also because it is unique as a habitat for several species of migrating waterfowl. Among these species are the sandhill cranes and the whooping cranes, which require a wide and shallow channel relatively free of vegetation for roosting and breeding. Maintaining these channel characteristics has caused concern in recent years because the Platte River channel has narrowed appreciably since the early $1950^{\prime} \mathrm{s}$. Before measures to prevent further narrowing can be taken, however, an examination of the hydrologic changes, which occurred along with the channel changes, is needed.

This report presents an appraisal of the changes in surface-water resources of the Platte River basin. In the appraisal, the following aspects 
were considered: (1) The present utilization of the surface-water supplies, (2) the historical flow characteristics of the streams, and (3) the effects of environmental factors on streamflow.

\section{PHYSICAL SETTING}

The South Platte and North Platte Rivers originate primarily as snowmelt streams in the Rocky Mountains of Colorado. They flow across the Great Plains to form the Platte River at their confluence at North Platte, Nebraska (fig. 1).

The South Platte originates in the central part of Colorado, flows southeastward to a point about $100 \mathrm{~km}$ (kilometers) southwest of Denver, flows northeastward, leaves the mountains about $50 \mathrm{~km}$ southwest of Denver, flows through Denver, and continues northeastward to the confluence with the North Platte River. Total drainage area of the South Platte River is about $62,900 \mathrm{~km}^{2}$ (square kilometers), and the river is about 720 river $\mathrm{km}$ long (Bentall, 1975, p. 6). The reach of the South Platte River studied extends from Kersey, Colorado, to the confluence with the North Platte River, a distance of about 380 river $\mathrm{km}$.

From its origin in north-central Colorado, the North Platte River flows northward into east-central Wyoming near Casper, and then flows southeastward to its confluence with the South Platte River. The North Platte River drains about $80,000 \mathrm{~km}^{2}$ and is about $1,050 \mathrm{~km}$ long. The reach of the North Platte River studied is from Lake McConaughy near Ogallala, Nebraska, to the confluence with the South Platte River, a distance of about 86 river $\mathrm{km}$.

The Platte River is formed at the confluence of the North Platte and South Platte Rivers. The Platte flows eastward through Nebraska to the Missouri River at the eastern edge of the State. The reach of the Platte River studied extends from North Platte to Duncan, Nebraska, a distance of about 460 river $\mathrm{km}$.

\section{CLIMATE}

Climate in the basin is affected by altitude, latitude, and topography. The Platte River basin has a continental-type climate, characterized by a large range of temperature and irregular annual and seasonal precipitation.

The mountainous region of the South Platte River basin has long winters, significant snowfall, and a short growing season. Precipitation varies in the mountains according to altitude; high mountainous areas along the Continental Divide average about $1,000 \mathrm{~mm}$ (millimeters) of precipitation annually.

Annual precipitation in the foothills averages about 400 to $500 \mathrm{~mm}$. Snowfall constitutes a smaller percentage of precipitation than in the moun- 


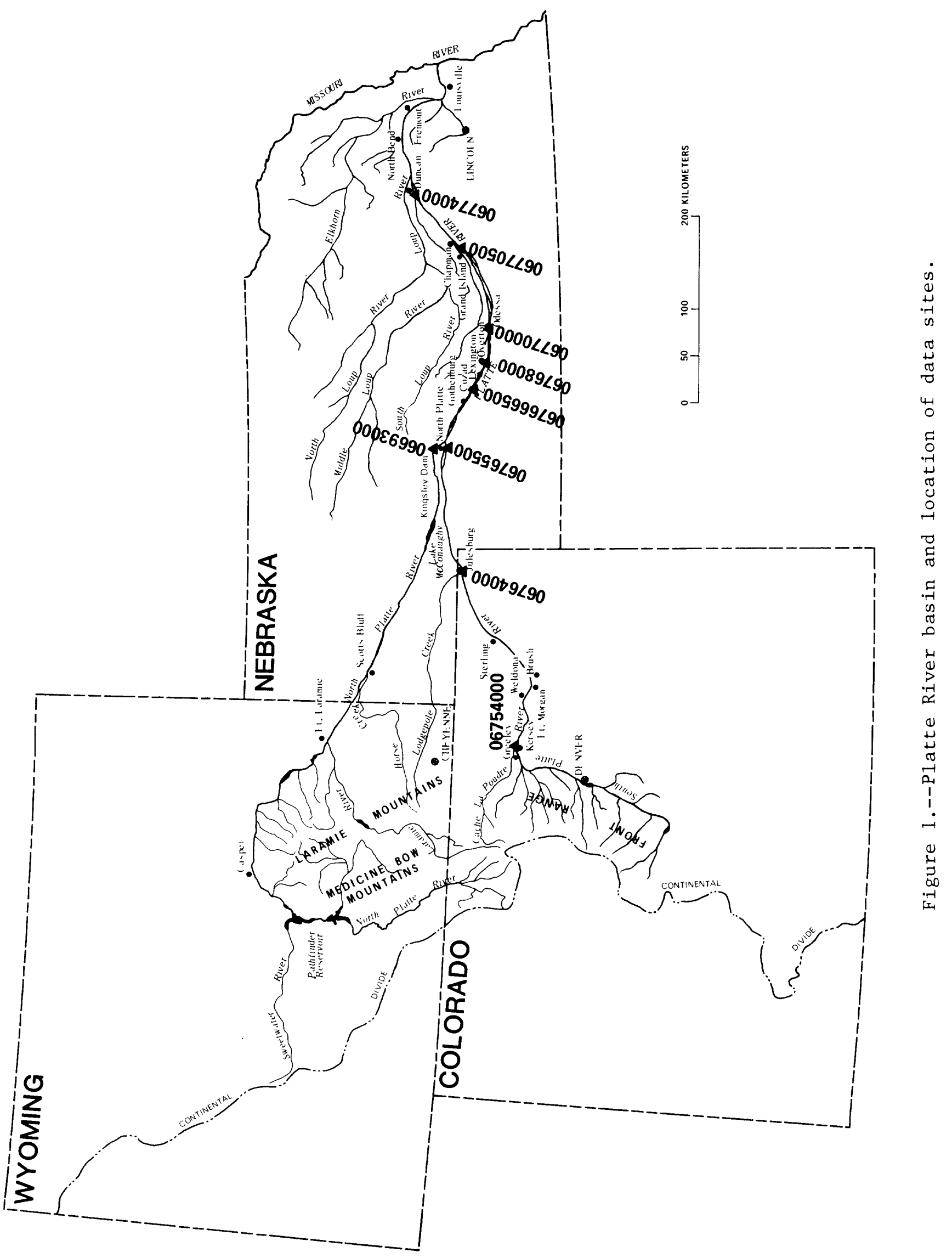


tains. Summer and winter temperatures in the foothills are more moderate than in either the mountains or the plains.

The plains region just east of the foothills has low humidity, warm summers, cold winters, and considerable year-to-year variation in precipitation. Average annual precipitation varies from approximately 300 to $460 \mathrm{~mm}$. Most of the precipitation occurs from April through September.

The climate of the North Platte River basin is about the same as that for the South Platte River basin. The climate generally can be characterized as semiarid with large fluctuations in temperature. Annual precipitation on most of the plains area ranges from 230 to $400 \mathrm{~mm}$; in mountainous areas from about 500 to $1,000 \mathrm{~mm}$.

The climate of the eastern plains of Nebraska is different, however, from the climate of the plains nearer the mountains. Precipitation across Nebraska is variable both geographically and seasonally. Average annual precipitation varies from about $380 \mathrm{~mm}$ at the western end of Nebraska to about $790 \mathrm{~mm}$ at the eastern end.

Mean annual precipitation at several locations within the basin is shown in table 1 . Total annual precipitation for each year of record for four precipitation stations in the basin is shown in figures 2 through 5.

The average annual evaporation from the basin as estimated by Meyers (1962) is tabulated in table 2. The entire basin as of 1962 had an annual evaporation of $1,447 \mathrm{hm}^{3}$ (cubic hectometers) (table 2). There have been reservoirs, ponds, and canals added since 1962 that will increase this amount.

\section{PRESENT UTILIZATION OF SURFACE WATERS}

\section{$\underline{\text { Storage Reservoirs }}$}

The P1atte River basin has 194 reservoirs that have useable-storage capacities greater than $0.6 \mathrm{hm}^{3}$. These reservoirs are listed in table 3 . The combined useable-storage capacity of the reservoirs is $8,829 \mathrm{hm}^{3}$. In addition to the reservoirs shown in table 3 , numerous small lakes and stock ponds are scattered throughout the study area.

\section{Transmountain Diversions}

The major transmountain diversions are located in Colorado and import water to the South Platte River. This imported water is collected from the Colorado River basin and the North Platte River basin and diverted to the South Platte basin for municipal, industrial, and irrigation uses. The average annual water diverted from western Colorado is $414 \mathrm{hm}^{3}$ (Gerlek, 1977). Development of conditional water rights may yield an additional 271 to $308 \mathrm{hm}^{3}$ per year of water from western slope diversions. 


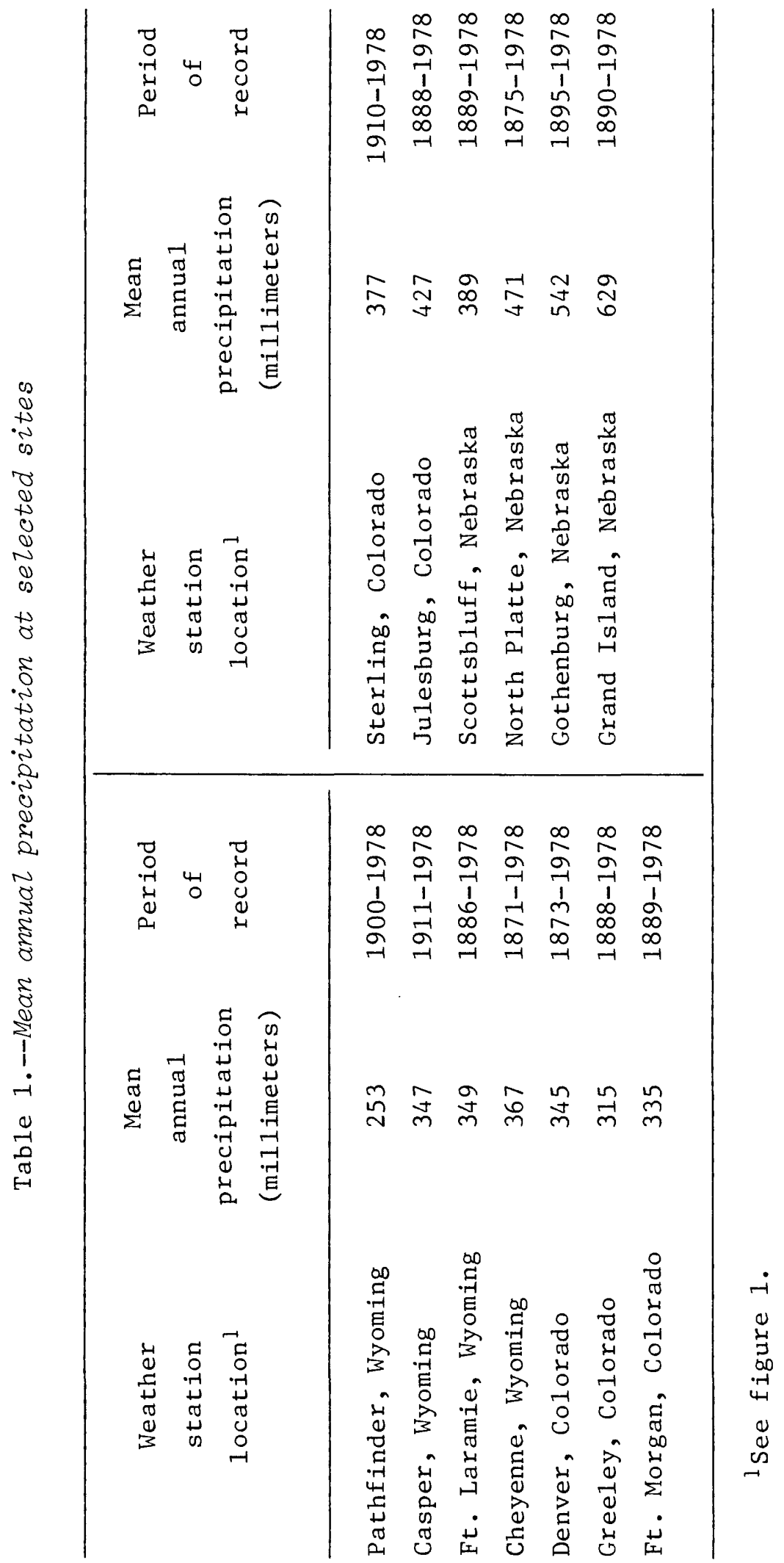




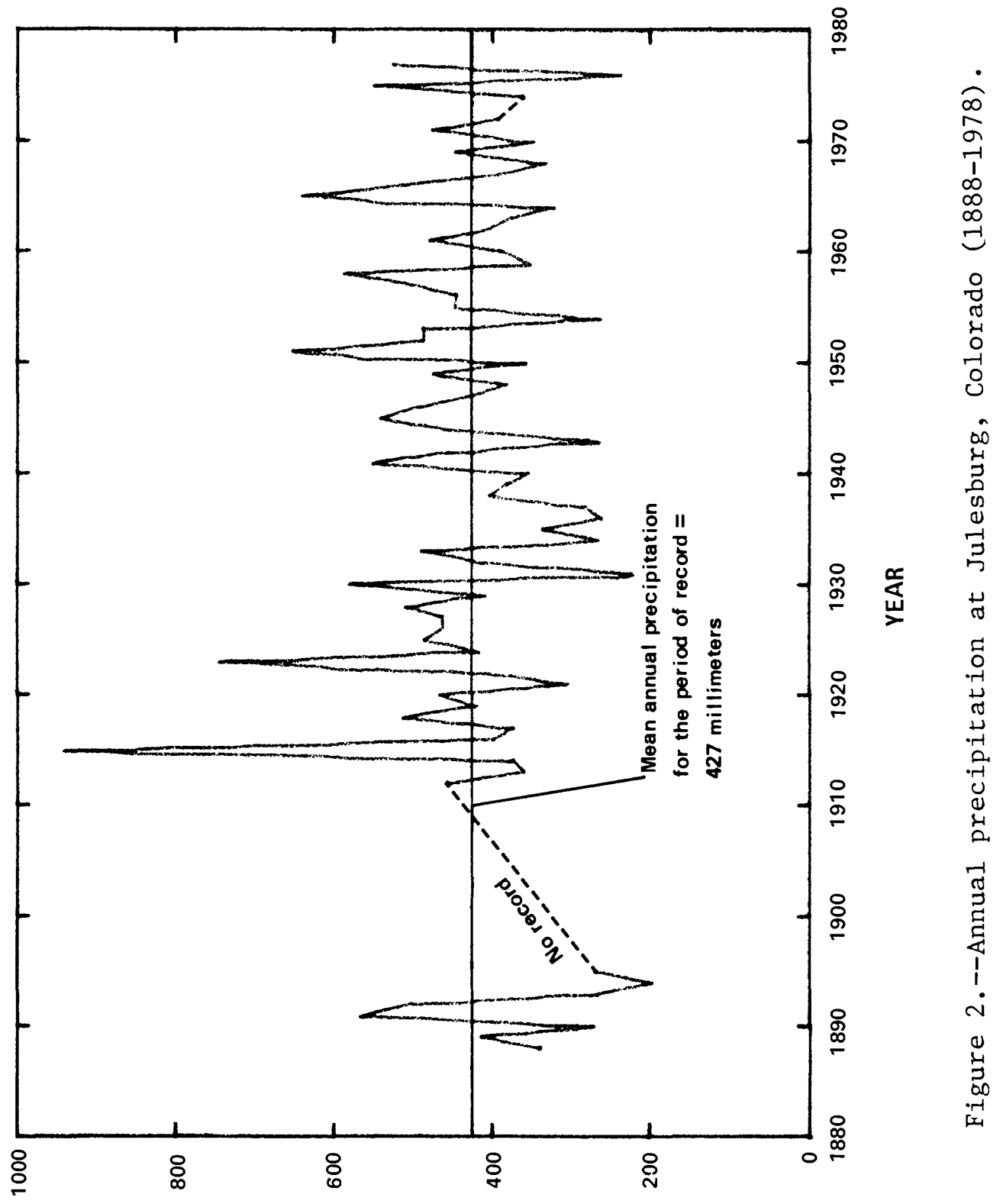

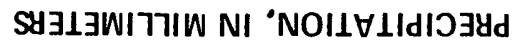




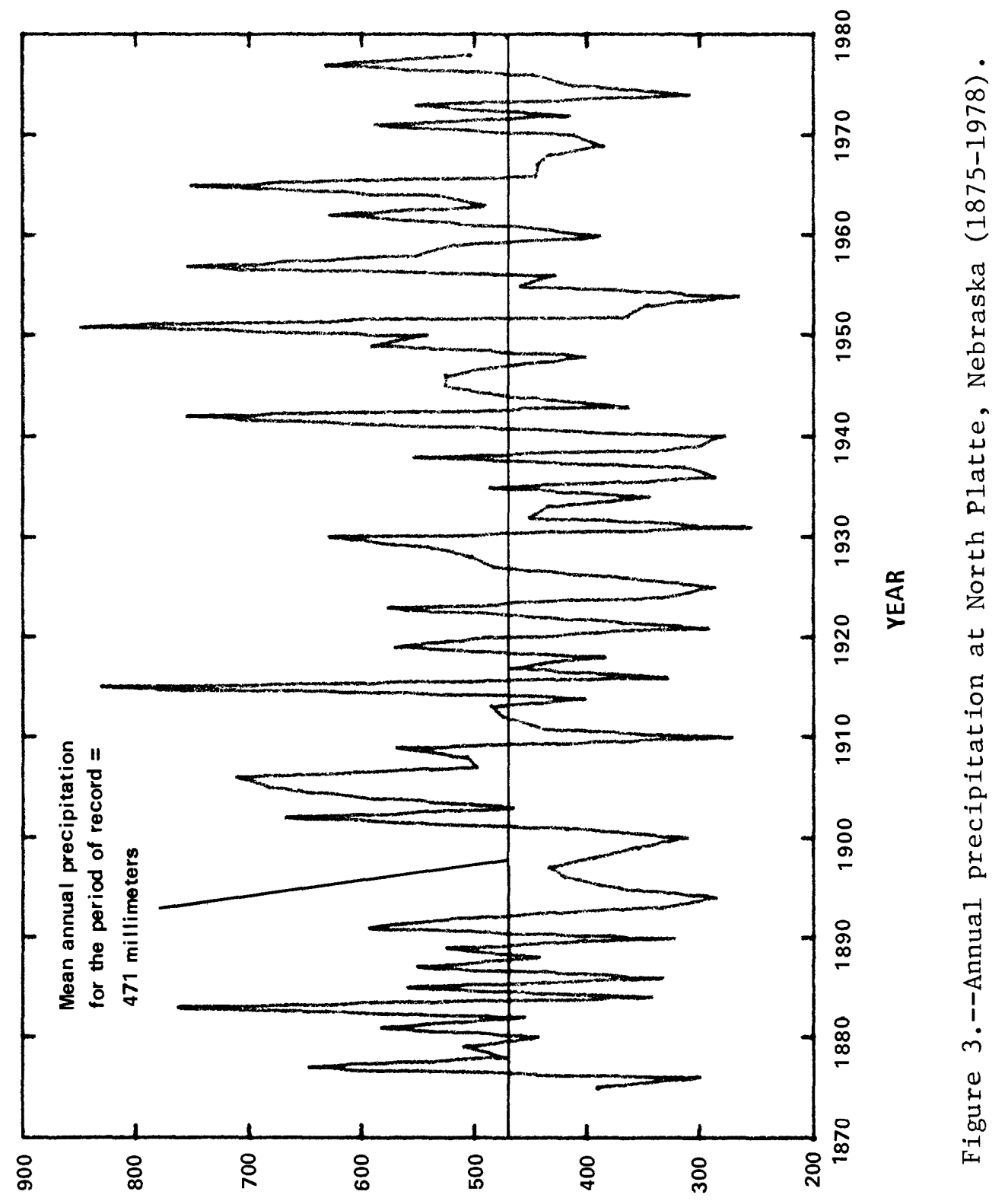

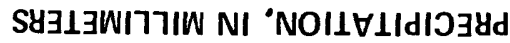




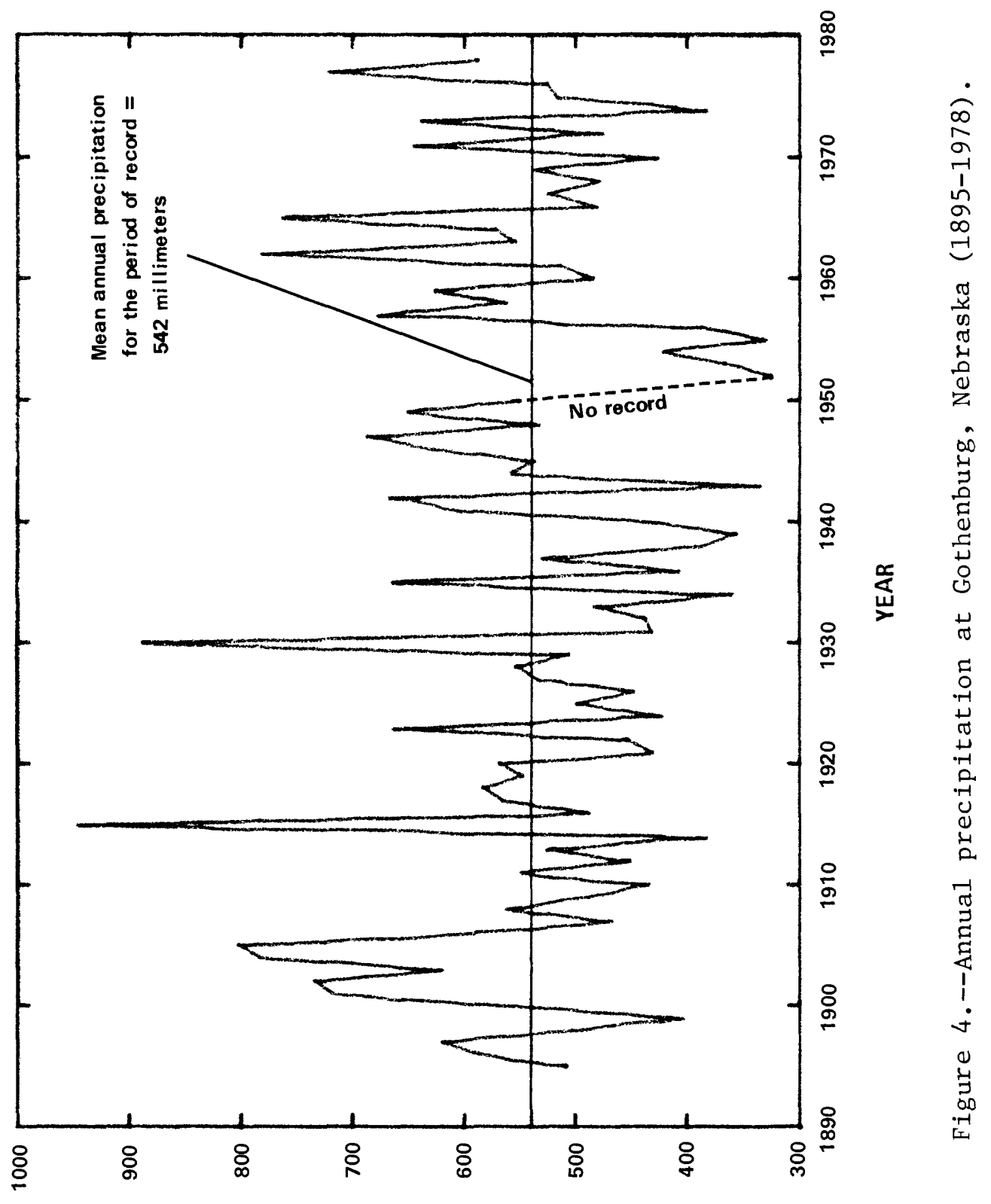

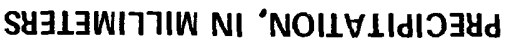




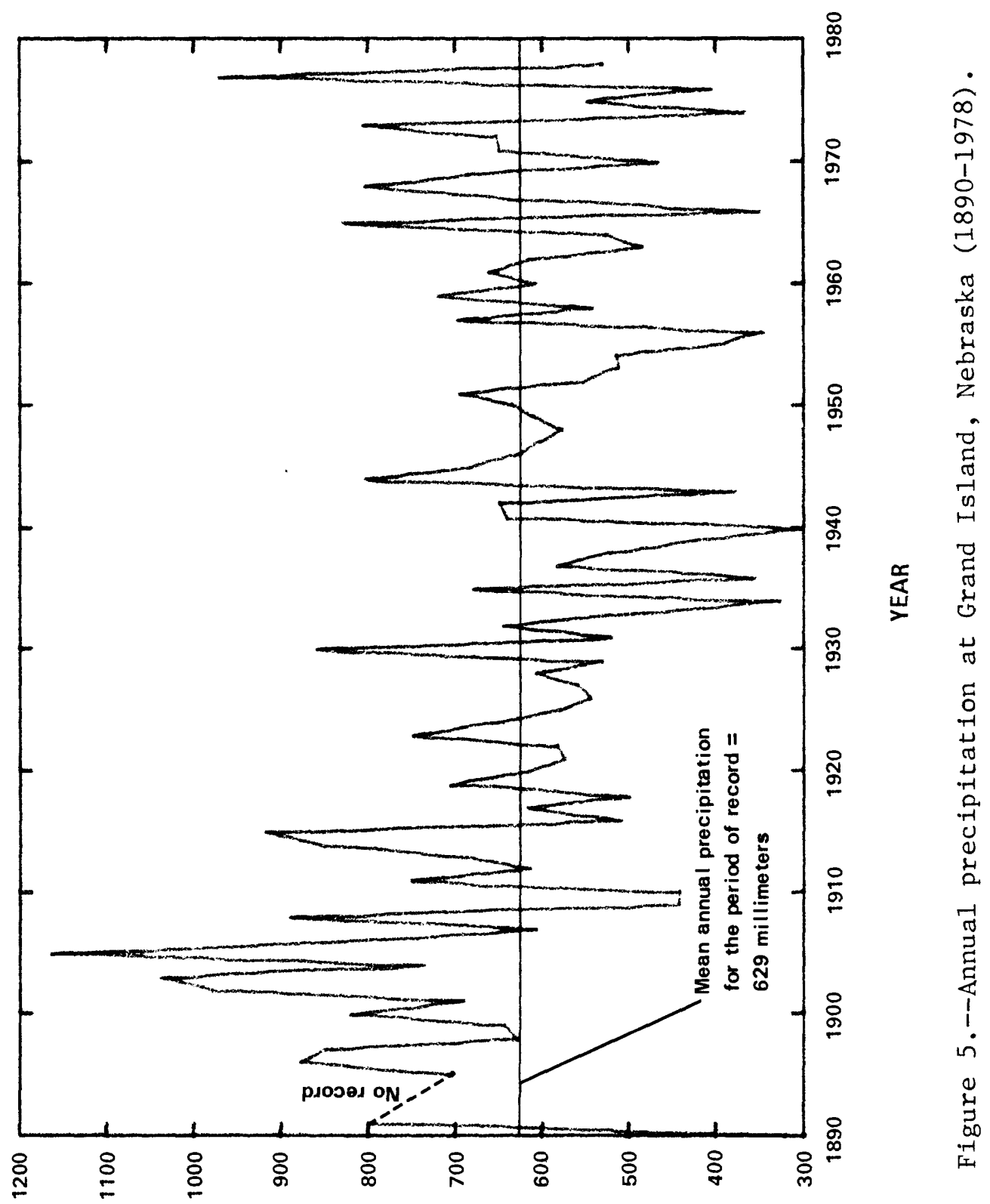

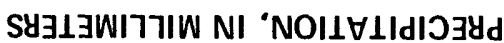




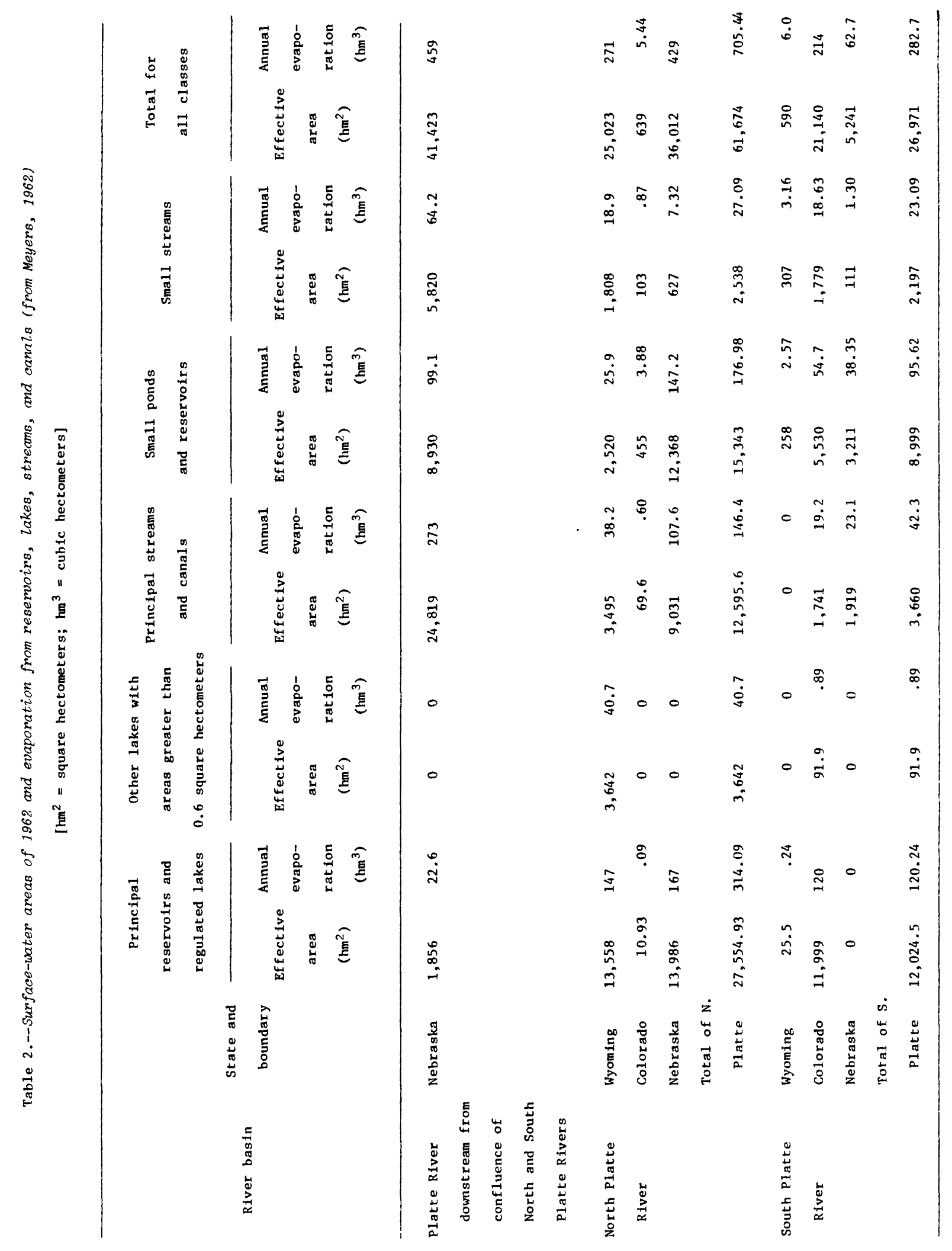




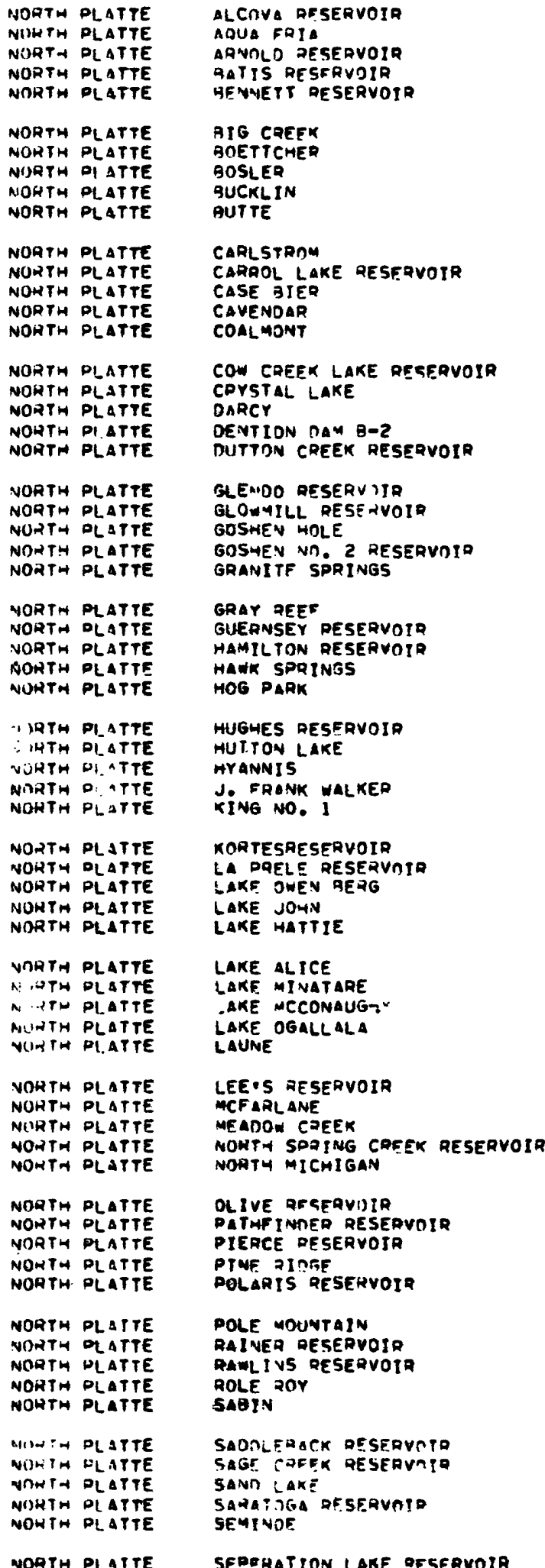

233.0

0.9

1.0

1.2

8.5

0.6

2.0

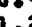

0.0

0.7

1.8

0.7

39.1

0.6

3.6

0.9

3.2

990.5

1.0

6.1

1.1

1.

2.2
5.8

1.2

20.6

3.8

0.8

2.6

0.7

2.7

5.7

2.5

1.7

8.0

14.1

76.7

2401 .

16.0

3.7

0.6

6.2

0.9

1.6

9.2

1319.3

40

2.7

2.3

0.7

0.8

i1. 0

3.9

0.8

1.0

1204.3

0.7 


\section{6 cubic hectometer--Continued}

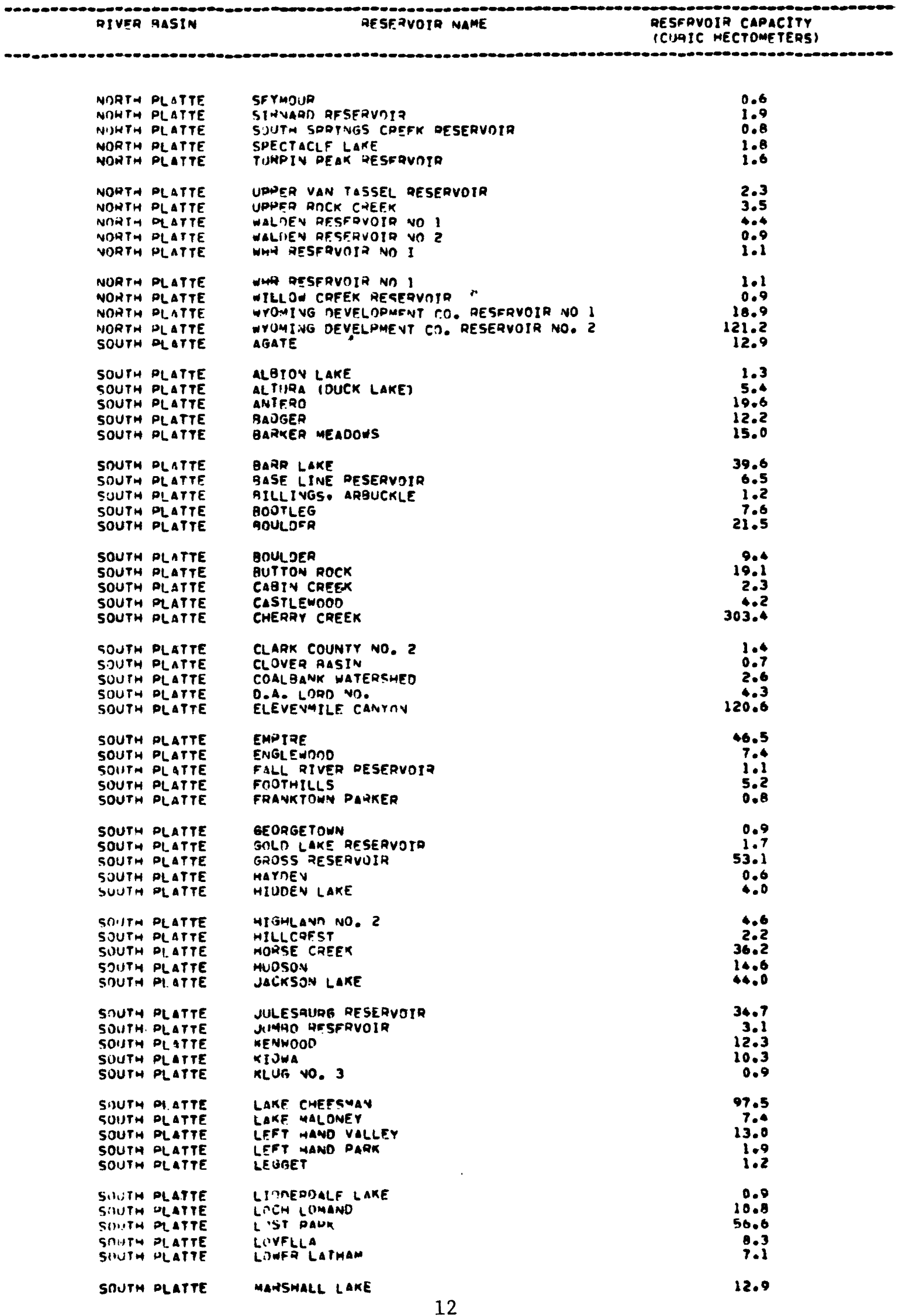


Table 3.--Reservoirs with capacities greater than

\section{6 cubic hectometer--Continued}

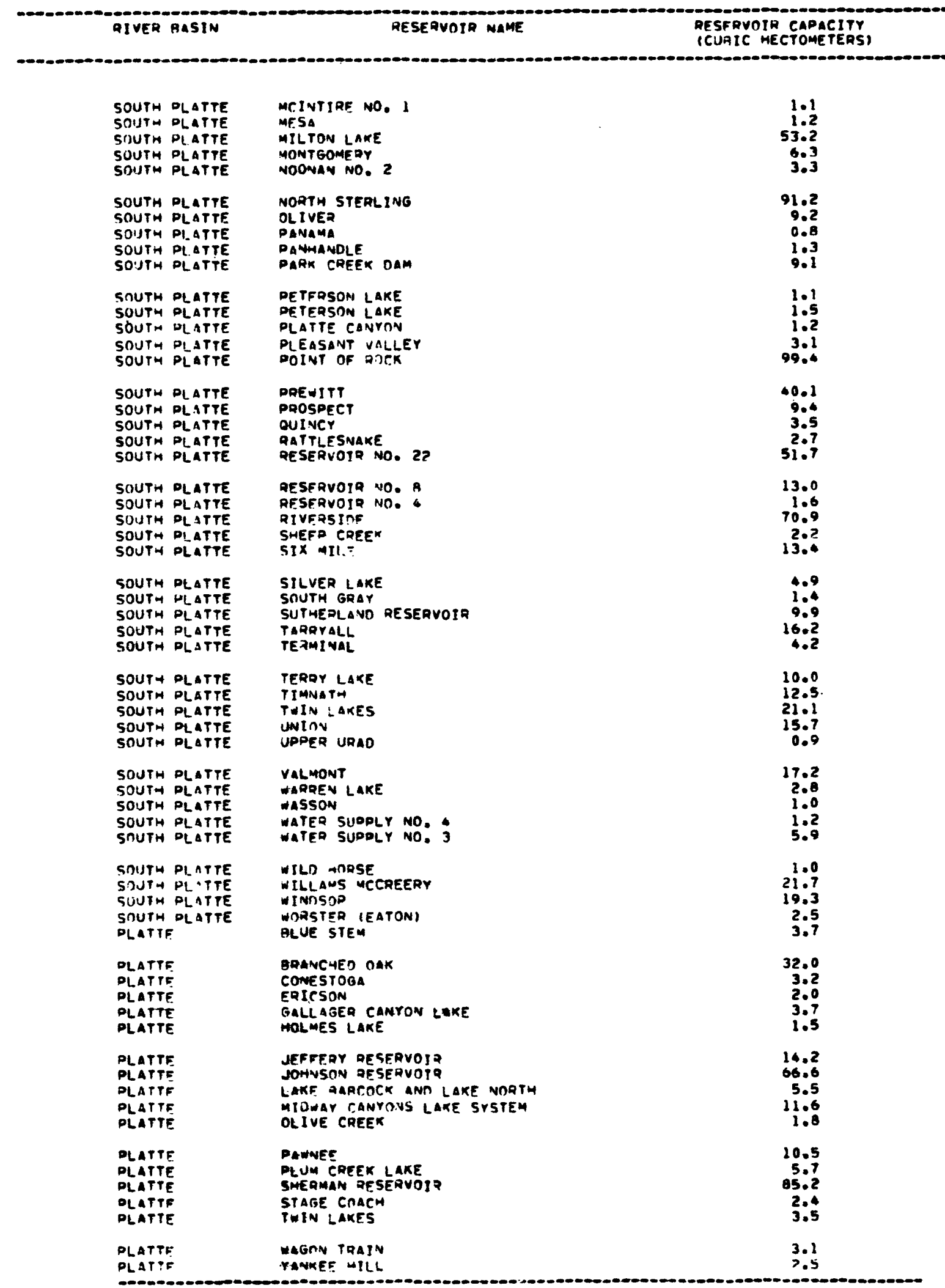




\section{$\underline{\text { Irrigation }}$}

Irrigation in the Platte River basin began during the early 1800's with the construction of small, wide ditches to small irrigated tracts of land on the flood plain adjacent to the river. Since that time, there have been many reservoirs built to store water and many elaborate canal and ditch systems built to more efficiently use surface water. The earliest development occurred on the Colorado and Wyoming plains where the climate necessitated having irrigation projects store water for use during the dry summer months.

Since the earliest irrigation projects, when only the land next to the rivers was used for agriculture, the irrigated land has increased to about $1.4 \mathrm{million} \mathrm{hm}$ (hectometers) in the entire basin. The area now is irrigated by means of direct diversions, reservoirs, and ground-water systems, and encompasses land several kilometers from the river.

\section{Domestic and Municipal Uses}

Several cities and industrial plants within the basin obtain water supplies from the river or from aquifers that are recharged mainly from the river. The muncipalities continue to grow at a rapid rate, especially along the Front Range of Colorado and coal-rich eastern Wyoming. This growth has been accompanied by increased water demands.

\section{HYDROLOGY}

\section{$\underline{\text { Genera1 }}$}

When the Platte River and its tributaries were virtually unregulated, spring runoff flowed unchecked down the mountain stream channels and onto the plains. During the summer after the snowpack melted, flow in these streams became very low. In the plains many of the rivers and tributaries were ephemeral, as most of the low flow infiltrated into the stream bed.

Today, after more than 100 years of irrigation and water-resource development in the basin, the Platte and its major tributaries, the North and South Platte, have changed from ephemeral streams to perennial streams. Spring runoff from the mountains now is diverted and stored in offstream reservoirs or retained by onstream reservoirs, to be used later in the year as needed. Through irrigation, much of the water is used on large tracts of agricultural land. The basin water balance also has been changed further by imported water from adjacent river basins.

The hundreds of reservoirs and the thousands of kilometers of unlined canals, ditches, feeders, and laterals have large seepage losses. As a result of this and of the irrigation practices used, the water tables have risen over the years making the plains' streams effluent; in other words, they gain water from irrigation return flows. These flows then are rediverted farther 
downstream leaving the channel dry below the point of diversion. This pattern of use and reuse extends along the length of the plains reaches of the South Platte, North Platte, and Platte Rivers.

The balance between diversions and return flows has been affected in recent years by extensive pumping from the riparian aquifer. This has had a serious effect on the surface-water users who are dependent on these groundwater seeps. Therefore, the practice of irrigation may have affected and overriden natural factors that normally define the hydrology of the Platte.

Because of these changes in the hydrology during the last 40 years, the Platte River channel has decreased in cross sectional area and the island area has increased (figs. 6-9). As a result, the channel has undergone considerable narrowing (fig. 10). Measurements made from aerial photographs were used in developing figures 6 through 10 . These changes in the Platte River have caused concern among wildlife managers interested in maintaining a suitable habitat for the thousands of migrating waterfowl that use the Platte in central Nebraska. The reach of river of concern extends from Lexington, Nebraska, to near Grand Island, Nebraska. This reach will be referred to throughout the remainder of the report as the critical habitat reach.

One of the potential consequences of the hydrology changes is a change in vegetation growth along and within the river channel. If channel bars are

exposed for a sufficient period of time, vegetation may become established, causing island formation and channel narrowing. Currier and Van Der Valk (1980) found that cottonwood and willow seeds begin falling about mid-May and continue to fall through mid-July. They state that after germination these seedlings could be viable until the end of August. If seed germination and seedling establishment is to occur, mud flats with significant soil moisture would have to be exposed for at least 1 to 2 weeks. Therefore, the investigation of hydrologic changes require special attention to the period from mid-May to the end of August, defined as the critical growth period for vegetation.

\section{Site Selection}

Nine sites along the Platte, North Platte, and South Platte Rivers were chosen for evaluation of flow changes. These sites are listed in table 4. Flow-duration curves and average 1-,3-, 7-, 15-, and 30-day mean high and 1-, 3-, 7-, 14-, and 30-day mean low flows were defined for all sites. For six of the nine sites, statistical analyses were performed on the annual mean flow and annual peak discharge records. The six sites chosen were the North Platte River at North Platte, Nebraska, the South Platte River near Kersey, Colorado, the South Platte River near Julesburg, Colorado, the South Platte River at North Platte, Nebraska, the Platte River near Overton, Nebraska, and the Platte River near Grand Island, Nebraska. These sites were chosen because the spatial and temporal coverage of flow data best represents the hydrology 


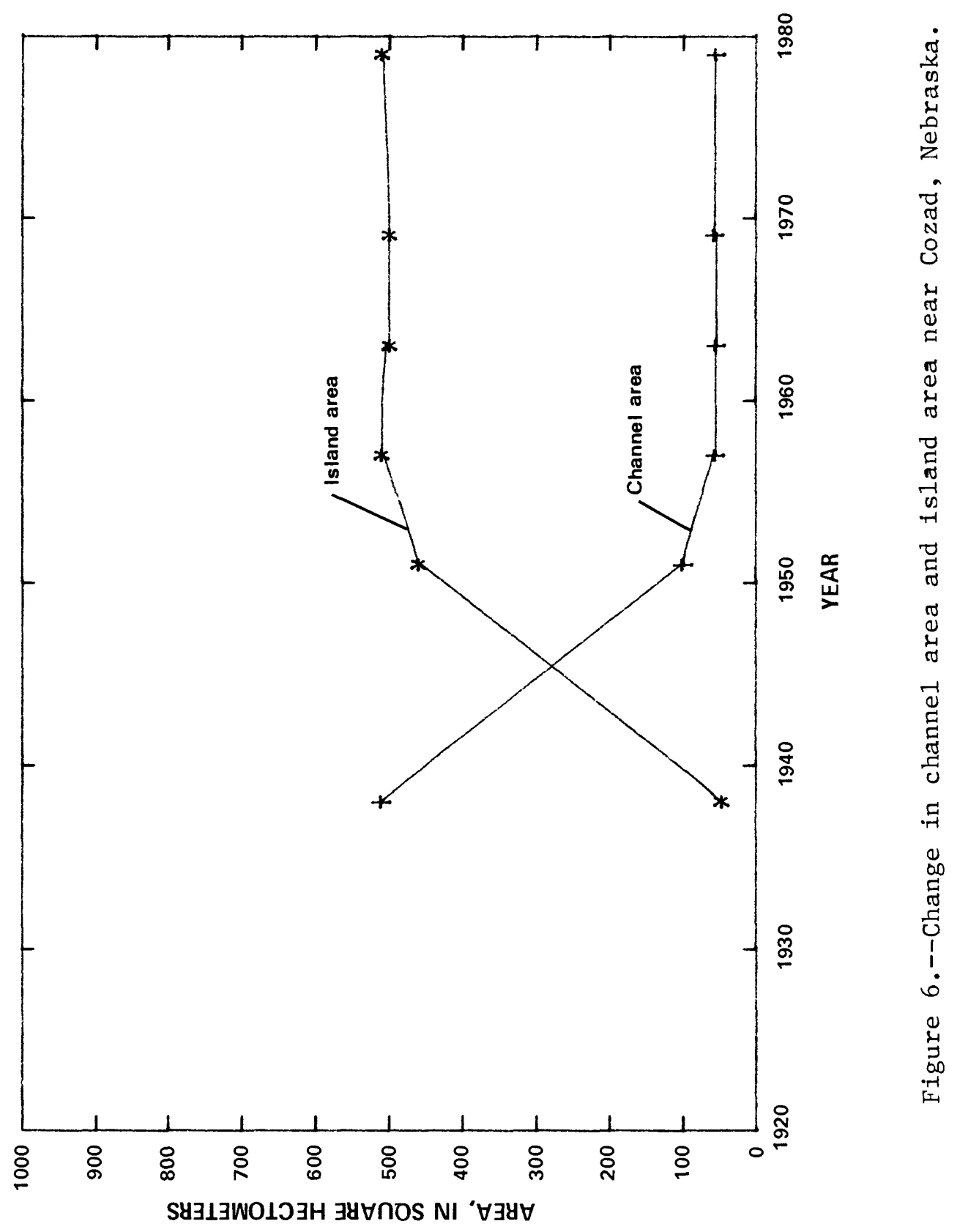




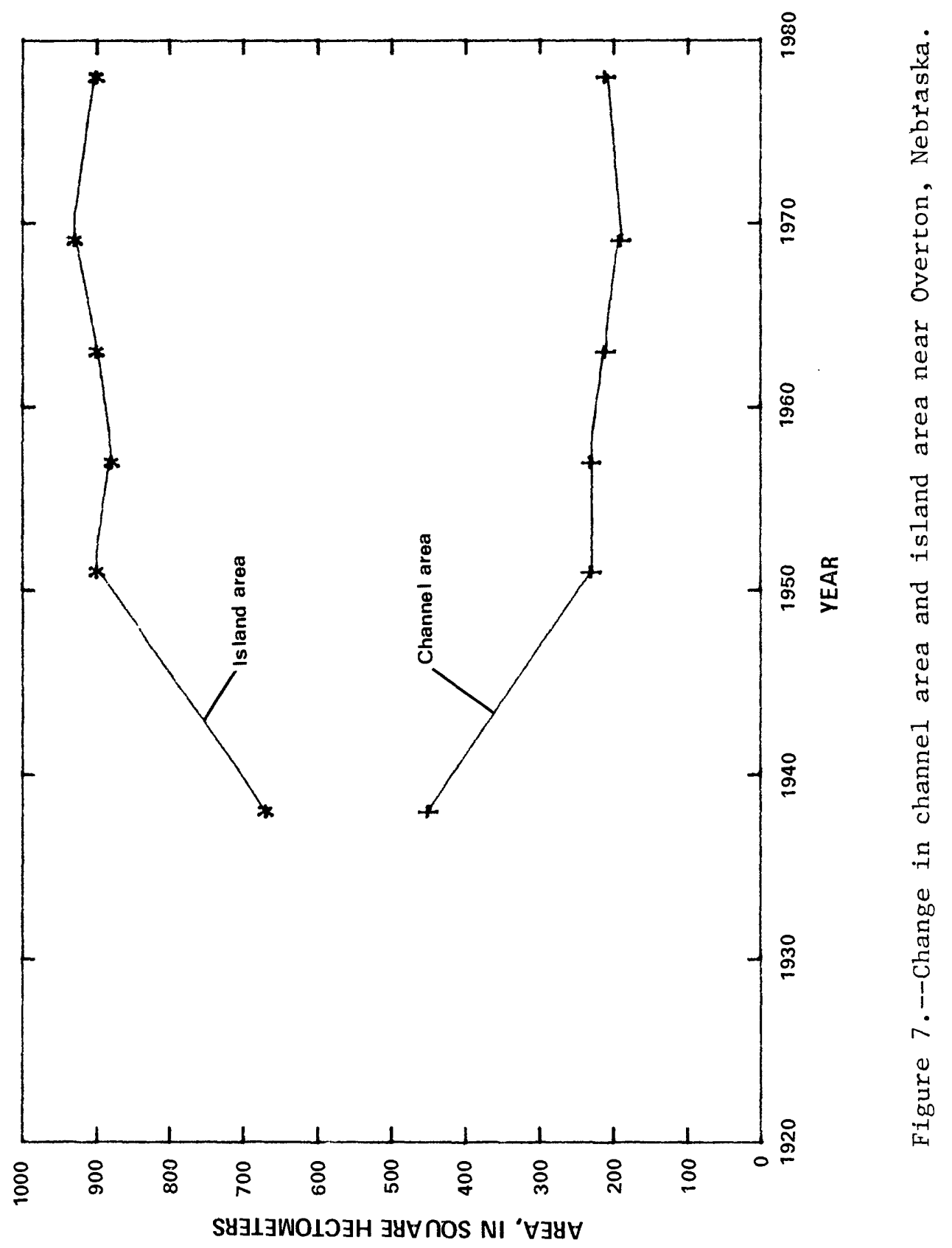




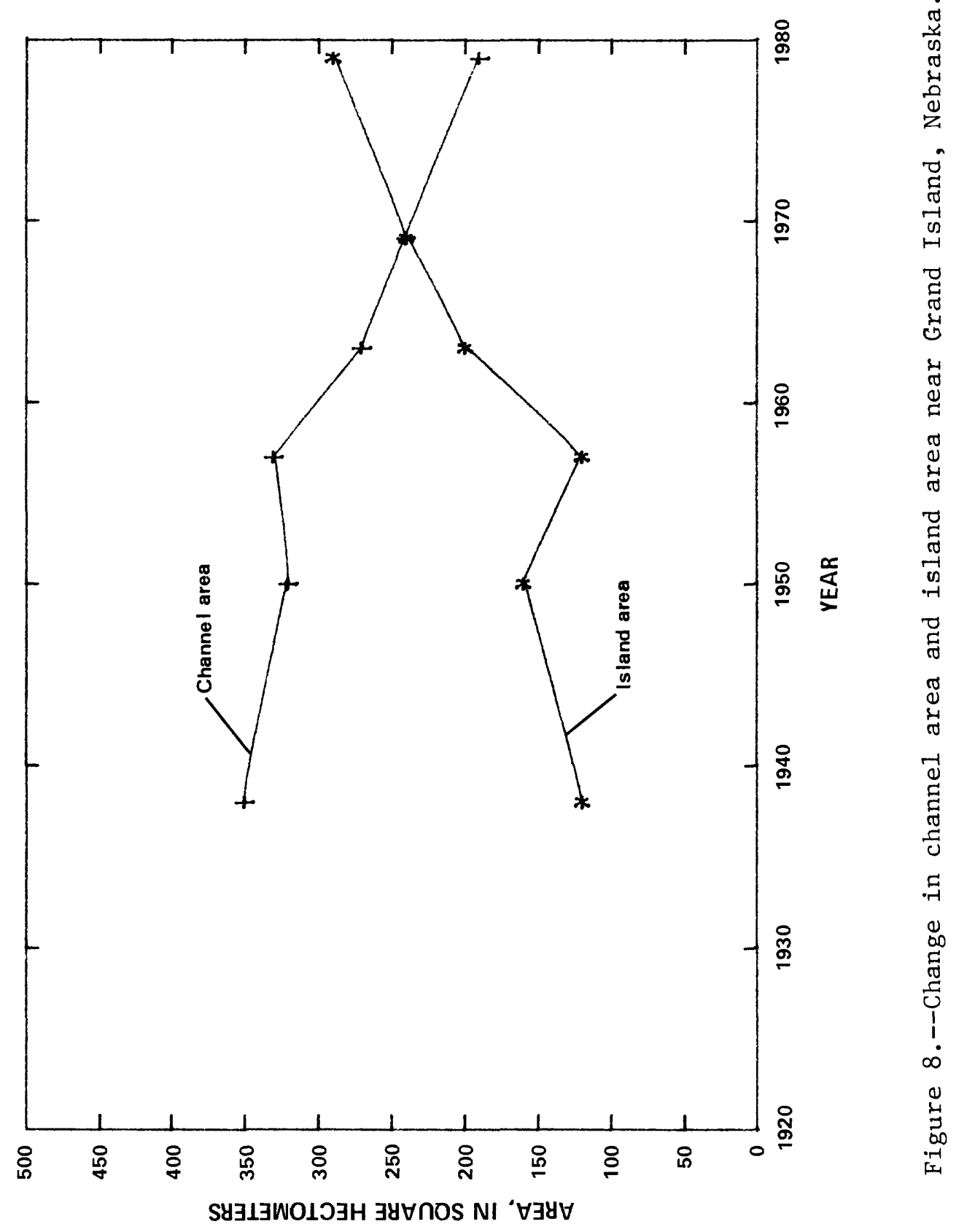




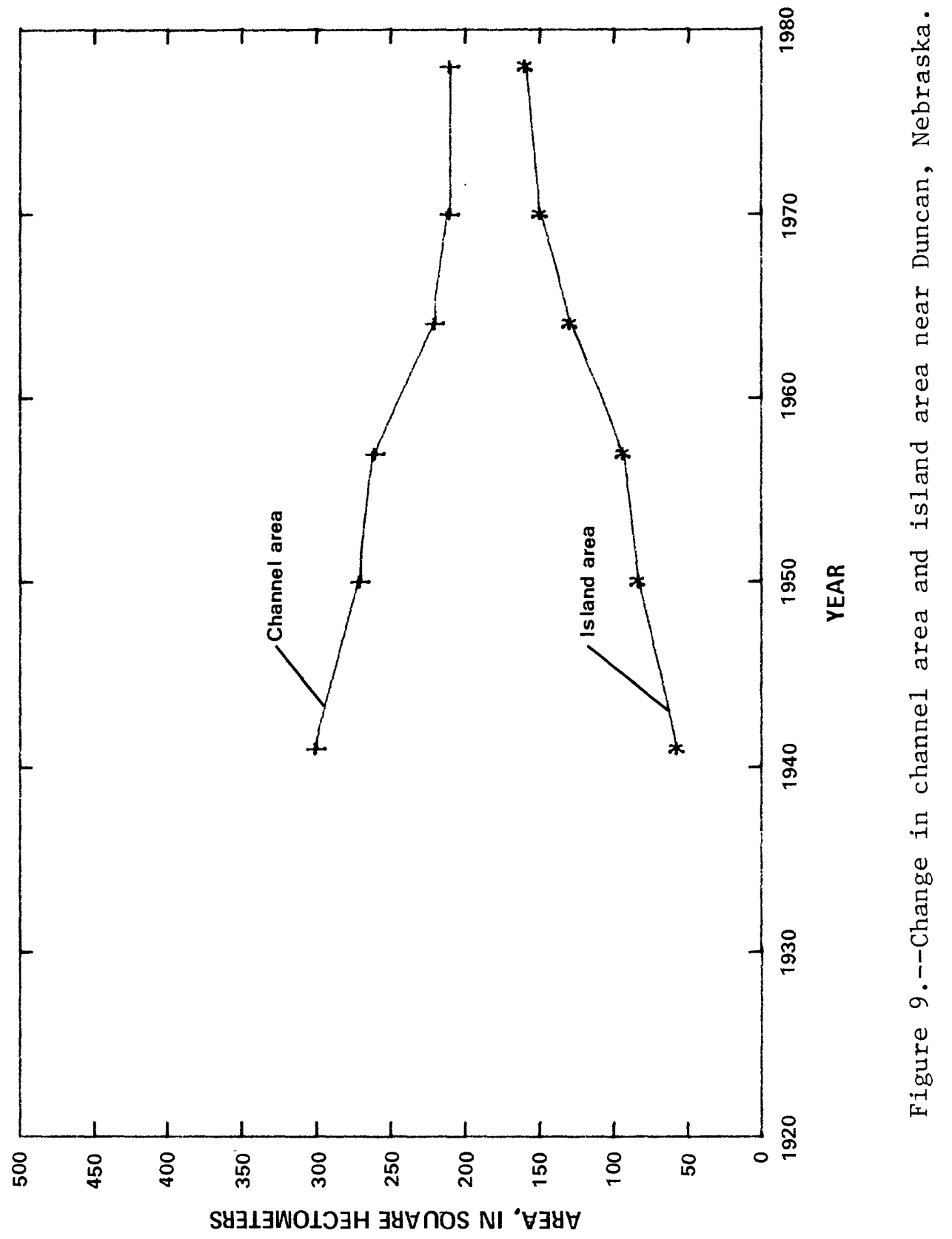




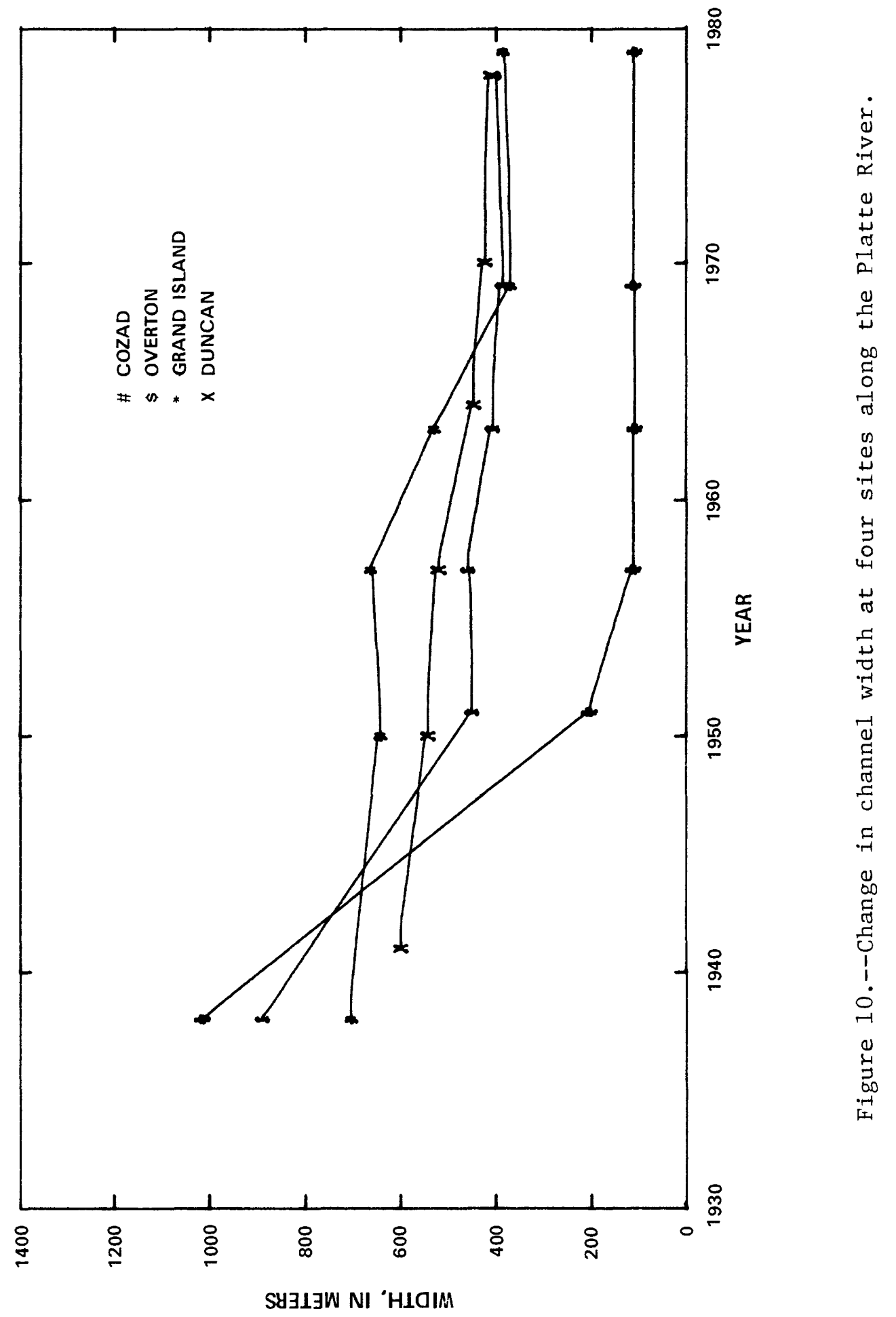




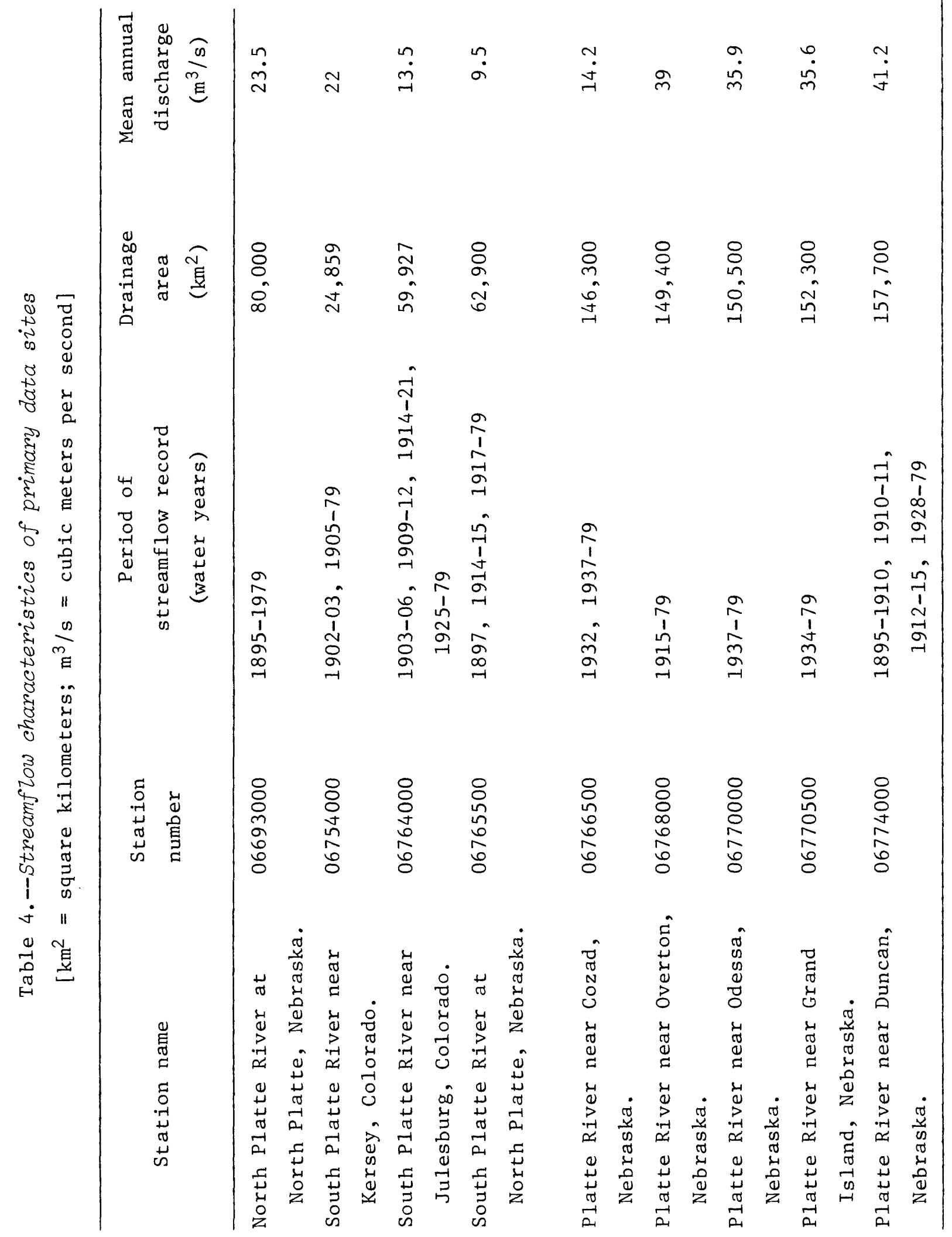


in the critical reach, as well as the reaches of the North Platte and South Platte Rivers that show the affect of the extensive development along these rivers that have had an effect on the critical reach. The results of the statistical analyses will be discussed later in the report.

\section{Flow-Duration Curves}

Flow-duration curves for 10-year intervals within the period of record at each of the nine selected stations, which show the percentage of time that water discharges of various magnitude have been equaled or exceeded, are given in figures 11 through 19. The flow-duration curves shown illustrate the progression of hydrologic change that has occurred within the basin. Although flow-duration curves for longer periods of record may have less time variability, it was believed that the longer-period flow duration curves might mask the nature of progressive change in the flow characteristics. For a discussion of defining the period or periods selected for computation of duration for a given station, see Riggs (1972).

The only station showing any major change in the upper end of the flowduration curve is the North Platte River at North Platte (fig. 11). All the 10-year periods following the 1931-39 period were smaller in magnitude and had a flatter slope except for 1970-79, which had several very high years of flow that may have caused the increase. This flattening indicates a decrease in the magnitude of high flows resulting from flow regulation occurring along the North Platte River. The remainder of the stations show very little change in the high flow section of the flow-duration curves, indicating no or very little change in the high flows.

The South Platte River near Kersey, Colorado, is the only station that shows very little change in the entire flow-duration curve sequence. This can be attributed partly to an increase in transmountain diversions of surface water. These diversions have been used to meet present municipal, industrial, and agricultural demands thereby resulting in very little change in the native water supply. As water use continues to increase along the Front Range, however, the flow characteristics for the Kersey station also may change.

The changes in the flow-duration curve sequences are indicative of the reduction in flow variability as one progresses downstream. The North Platte River at North Platte, Nebraska, the South Platte River at Julesburg, Colorado, and North Platte, Nebraska, and the Platte River near Overton, Nebraska, show a flattening in the lower end of flow-duration curves beginning about 1950 and continuing to 1979. This flattening usually is due to an increase of inflows caused by irrigation return flows or controlled release from reservoirs that maintain streamflow during low-flow periods. The period of record for the Platte River near Cozad, Nebraska, is too short to detect any obvious flattening of the flow-duration curves from those prior to 1940 . The flowduration curves for the gaging stations at Platte River near Odessa, Grand 


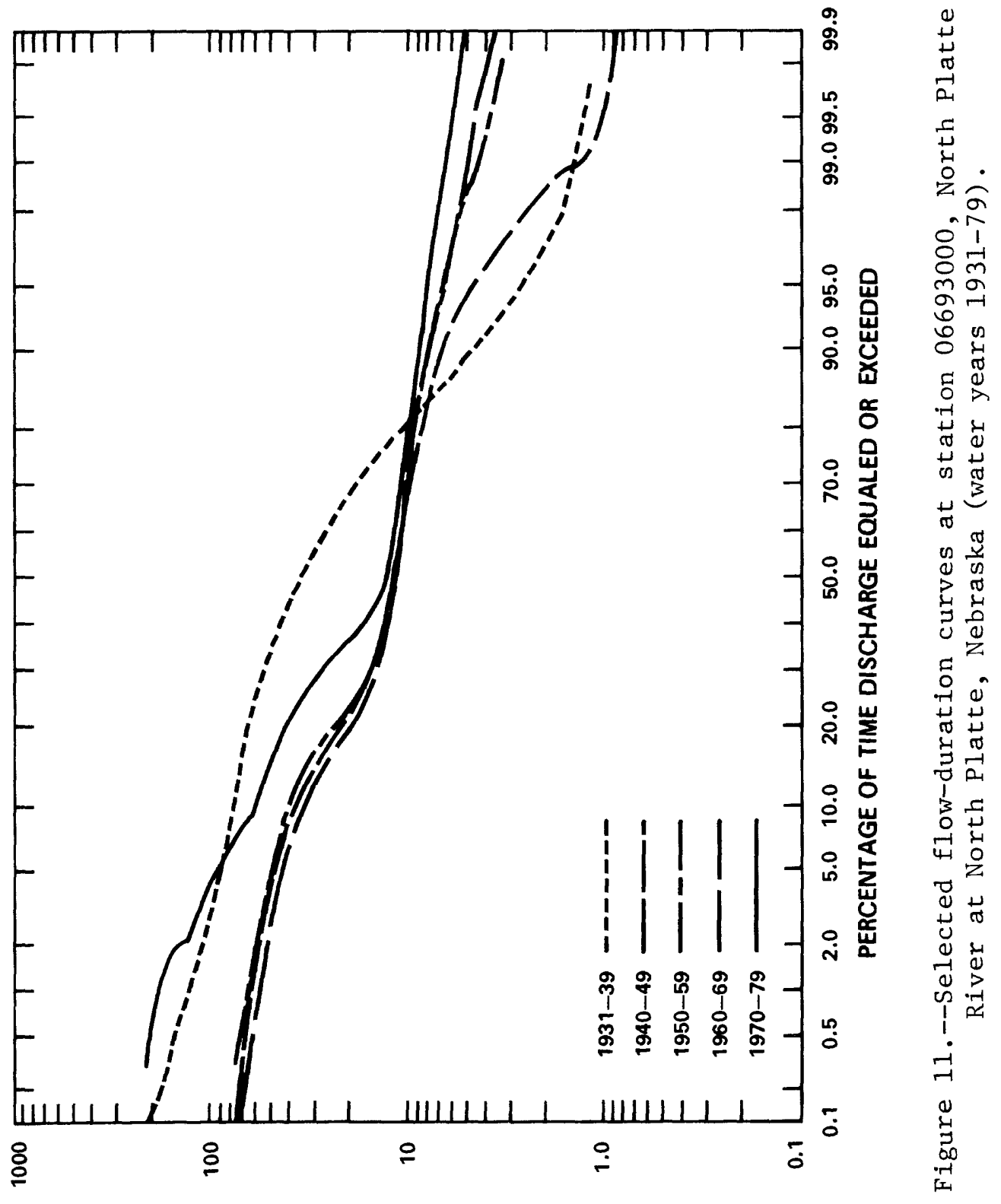

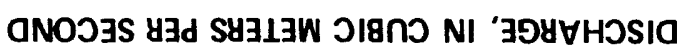




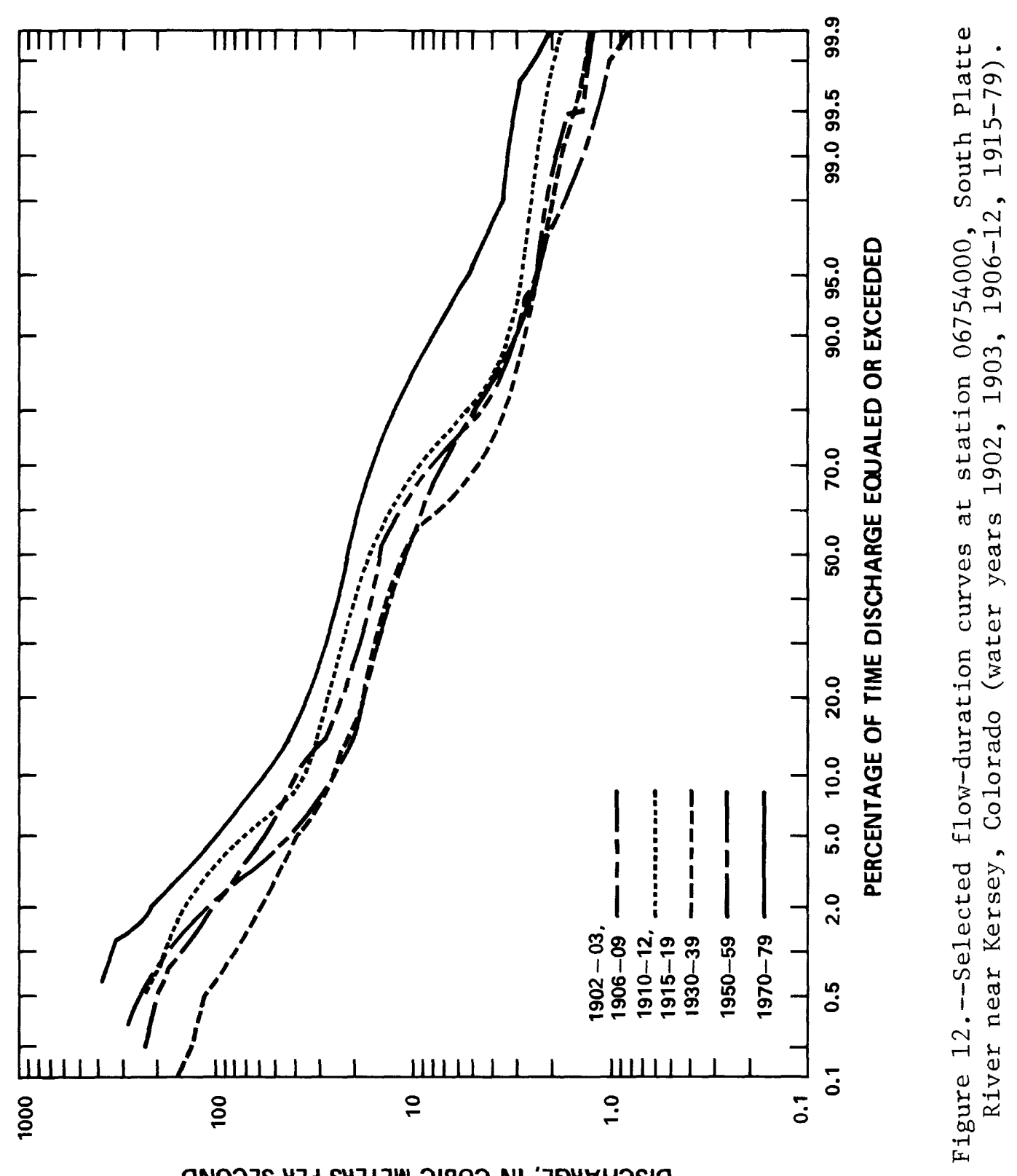




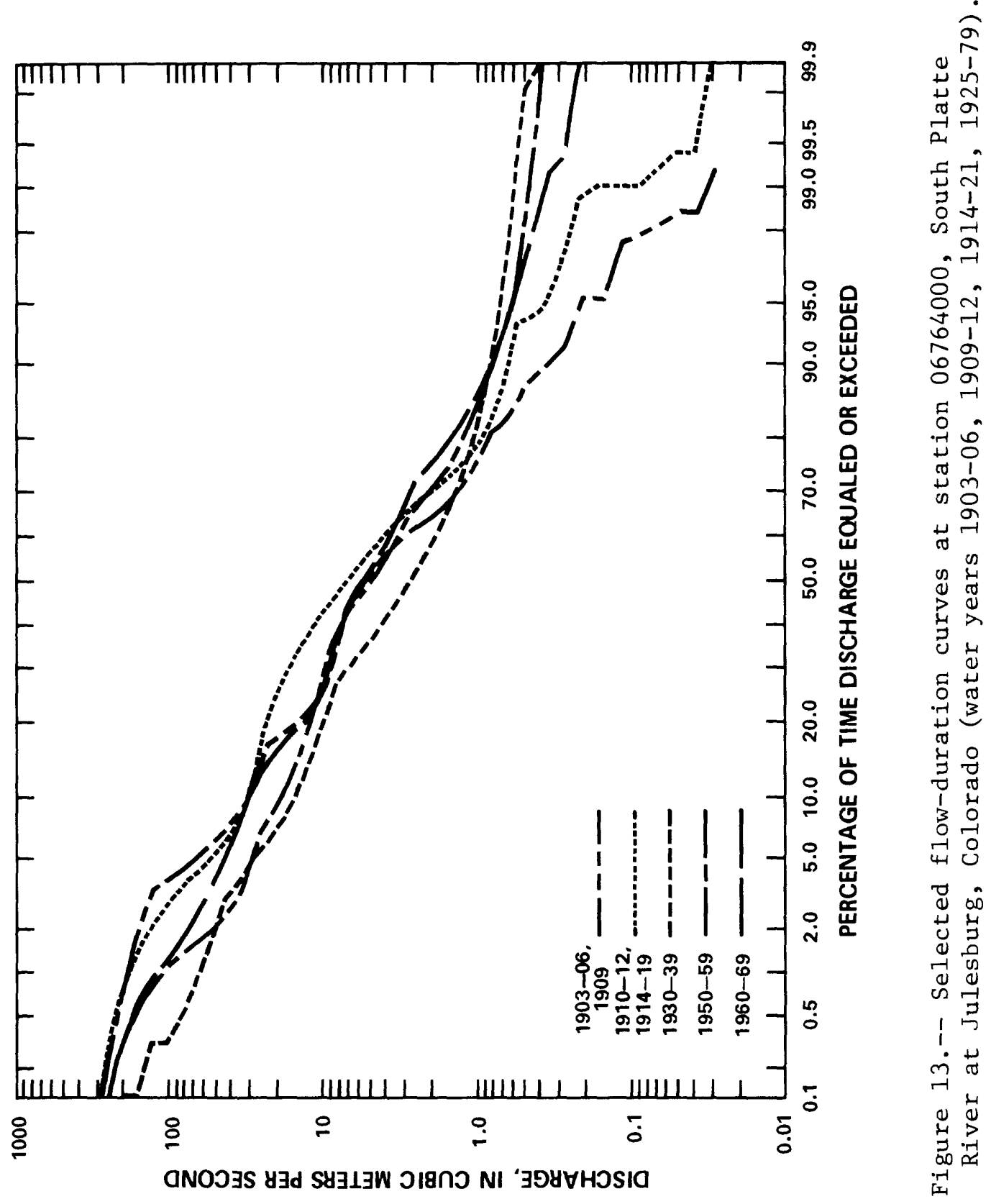




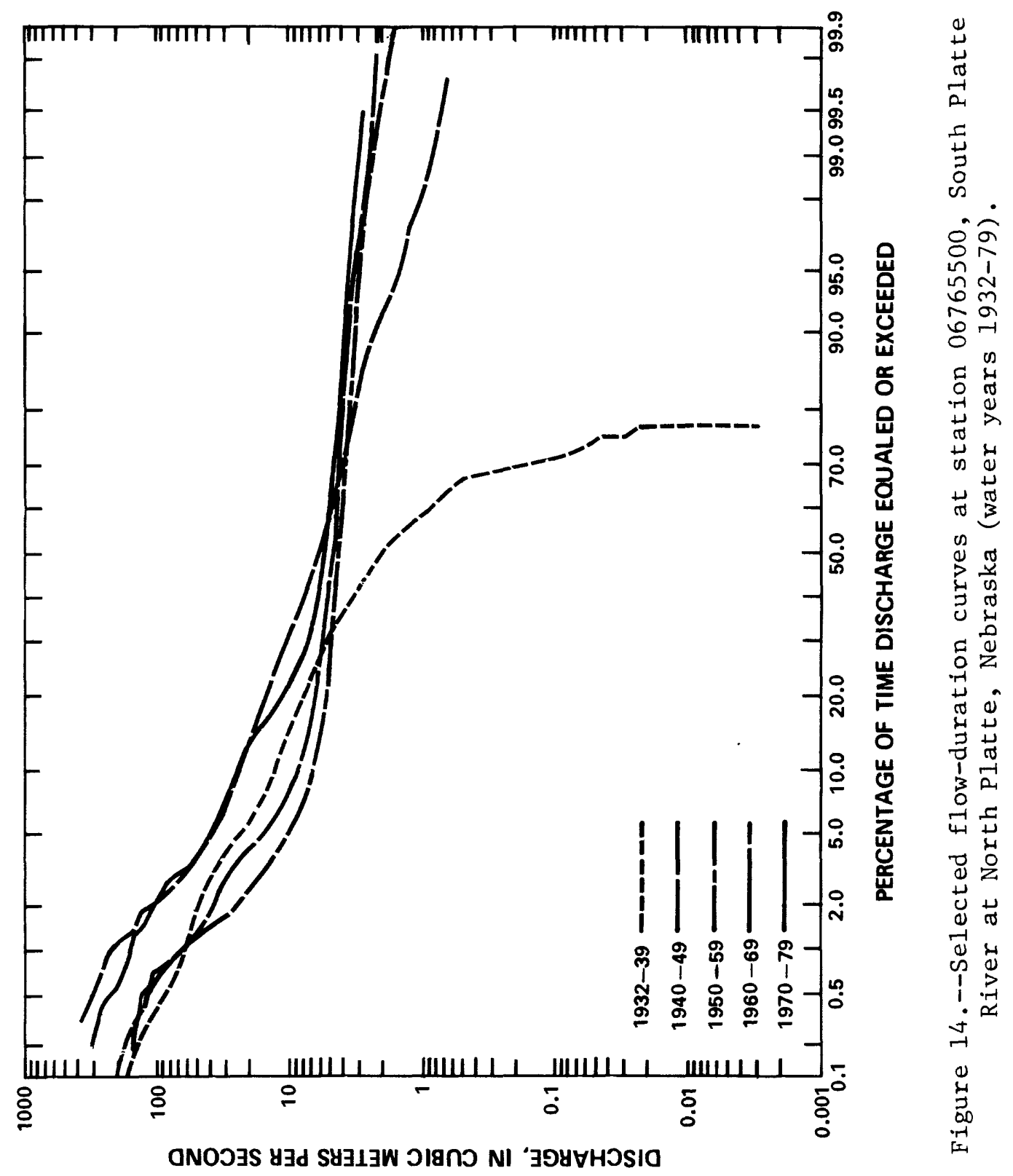




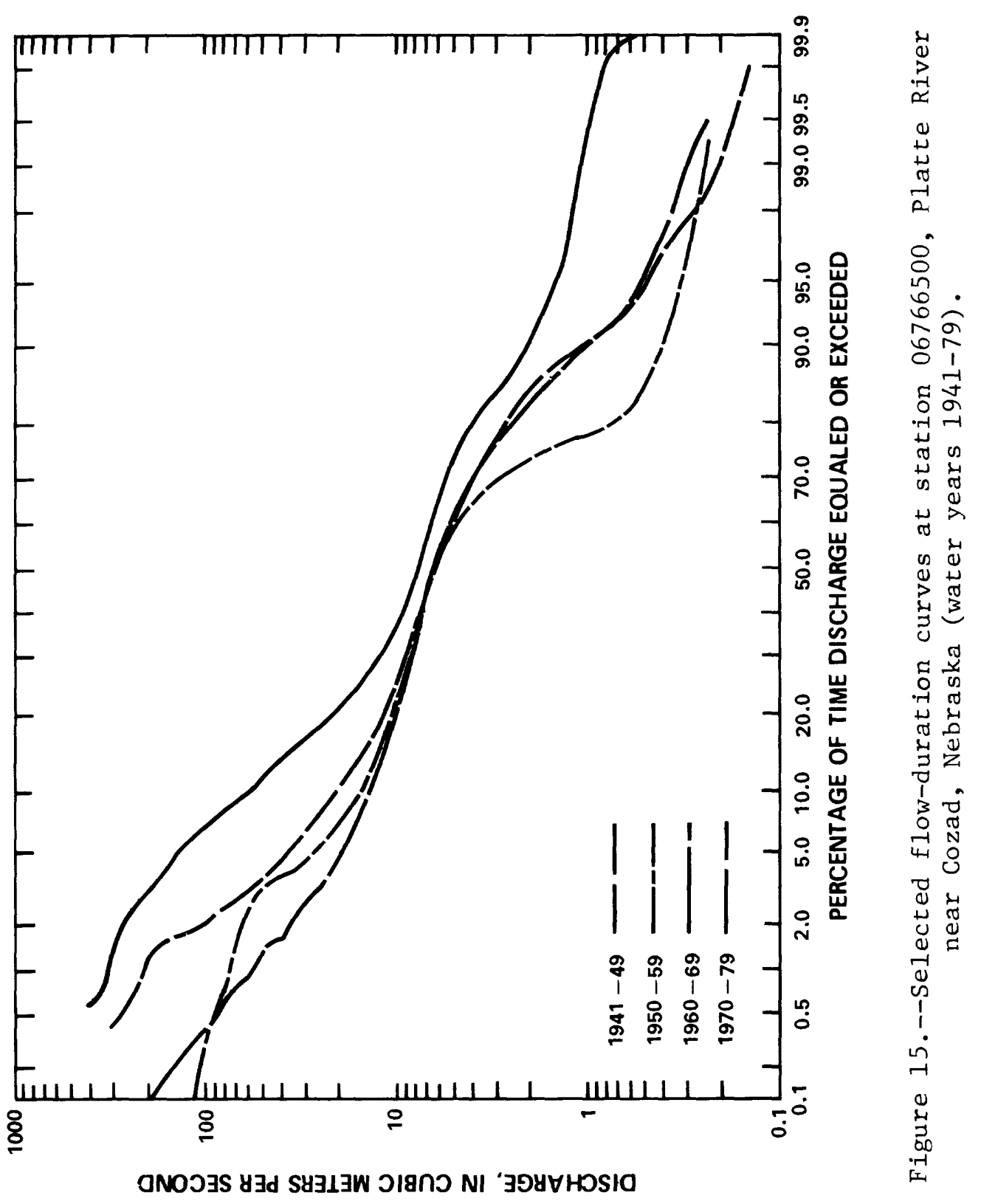




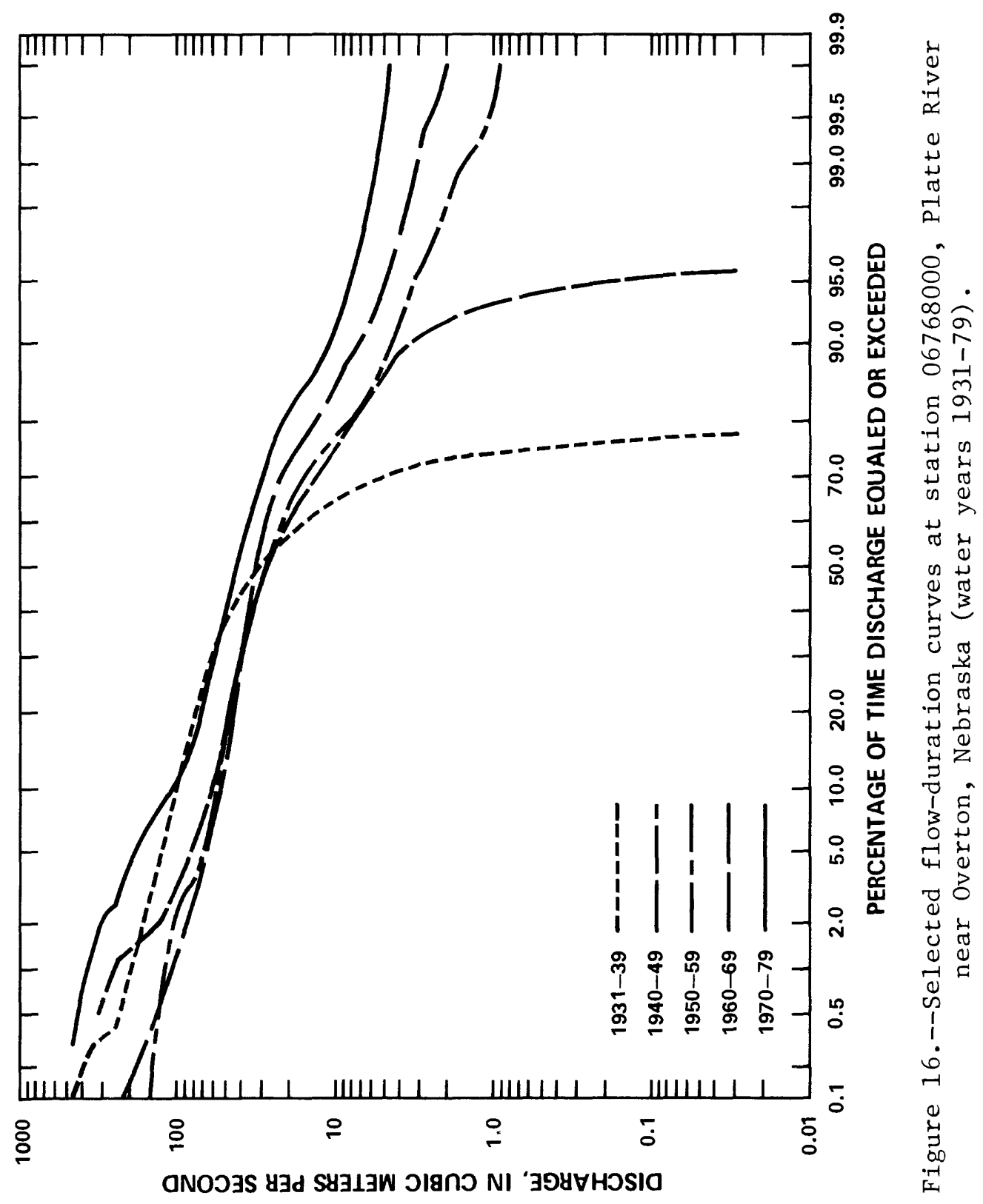




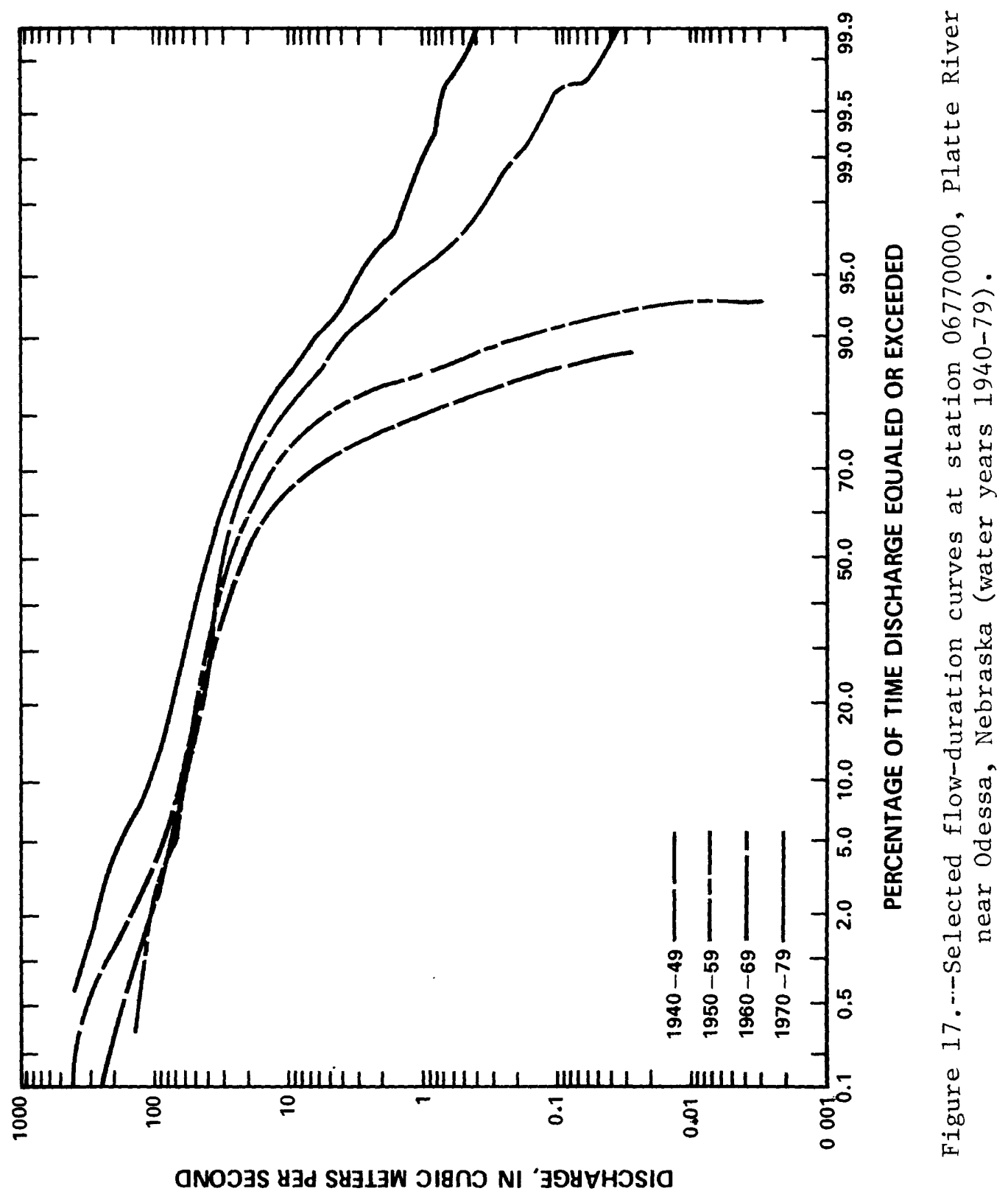




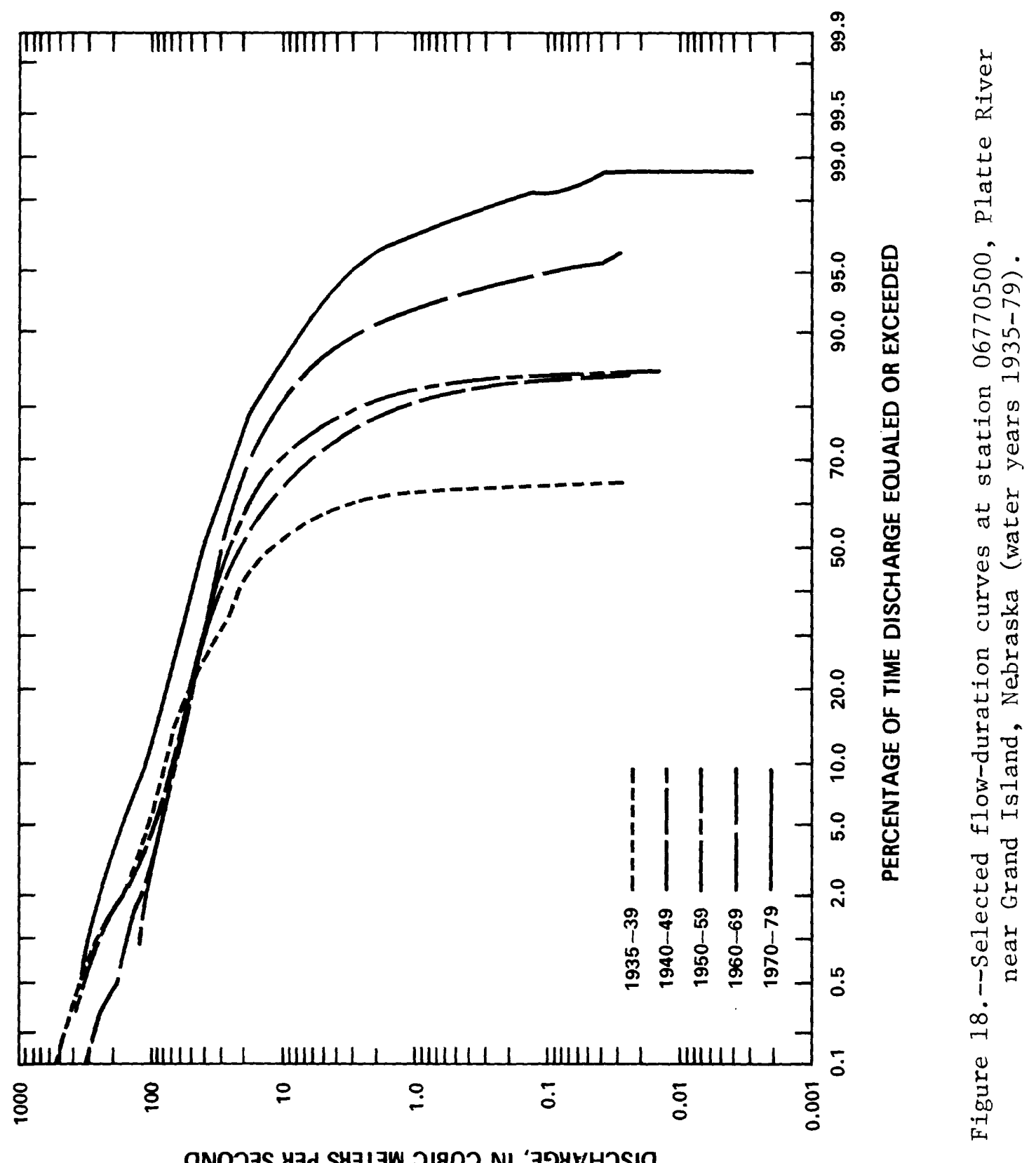




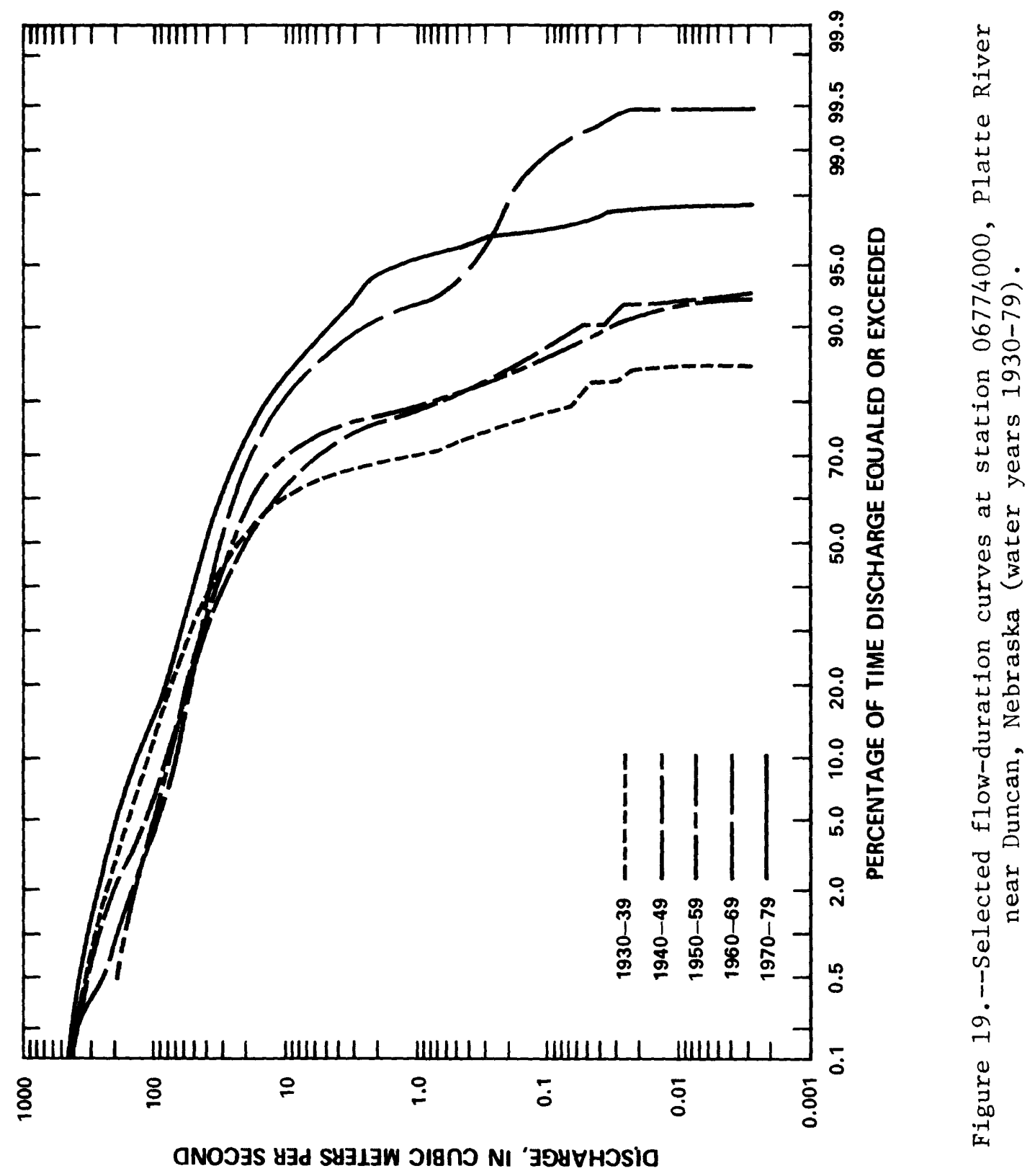


Island, and Duncan, Nebraska, are progressively flattening at the low-flow end. Changes in the shapes of the flow-duration curves can be related to the channel width and area changes already shown in figures 6 through 10 .

It should be emphasized that a distinction be made between change in shape of flow-duration curves and shift in flow-duration curves for different periods of record. A change in the shape of a flow-duration curve indicates change in the characteristics of flow distribution. This is the basis of the preceding analysis. A shift in a flow-duration curve, however, indicates a change in flow volume, but not distribution shape. A change in shape from 1940-49 to 1950-59 and a change in volume from 1960-69 to 1970-79 are shown in figure 16.

Further interpretation of the flow-duration curves may be made using periods of records longer than 10 years. Again using figure 16 as an illustration, an analysis could have been made using two periods, 1931-49 and 1950-79. It is apparent that the resulting flow-duration curves would lie somewhere between the respective 10-year period curves as plotted. The resulting two curves would allow one to relate the changes in water use and environmental factors to flow characteristics between the two periods.

\section{High Flows}

High flows, as used in this section, are defined as the largest mean flows occurring for durations of $1,3,7,15$, or 30 consecutive days for any given year. Changes in the mean high flows in the study reach are presented in figures 20 through 28. The North Platte River at North Platte, Nebraska, shows a general decrease in the high mean flows coinciding with the establishment of Lake McConaughy during 1941. In 1971 and 1973, however, a unique combination of large holdovers in the reservoirs and large inflows into the reservoirs, because of rapid snowmelt along with simultaneous heavy rains on the Nebraska part of the drainage basin, resulted in higher than normal releases from the reservoir (Shaffer, 1976). The two peaks on the high-flow graphs are not felt to indicate a sustained upward trend in mean high flows. This also was shown in the flow-duration curves with a flattening of the curves. The remainder of the stations, however, show little change in high flows.

\section{Low Flows}

Low flows, as used in this section, are defined as the smallest mean flows occurring for durations of $1,3,7,14$, or 30 consecutive days for any given year. The 1-, 3-, 7-, 14-, and 30-day low flows for each of the nine stations are presented in figures 29 through 37. The North Platte River at North Platte, the South Platte River at North Platte, and the Platte River near Cozad and Overton, show an increase in the minimum level of low flows since about 1940, while the South Platte River at Julesburg, Colorado, shows an increase, starting about 1920. The South Platte River near Kersey, Colorado, 


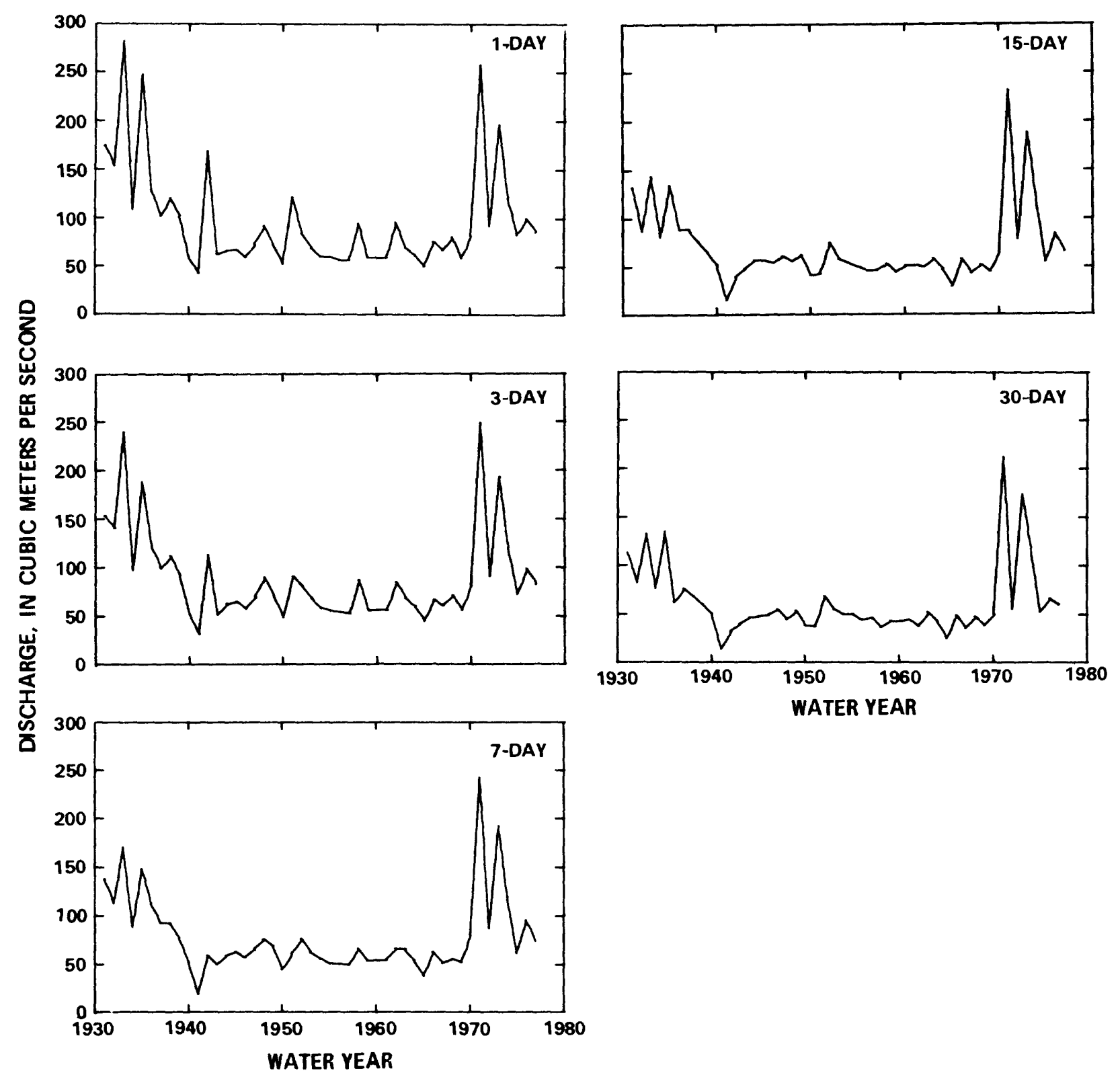

Figure 20.--Mean 1-, 3-, 7-, 15-, and 30-day high flows at station 06693000, North Platte River at North Platte, Nebraska (water years 1931-79). 


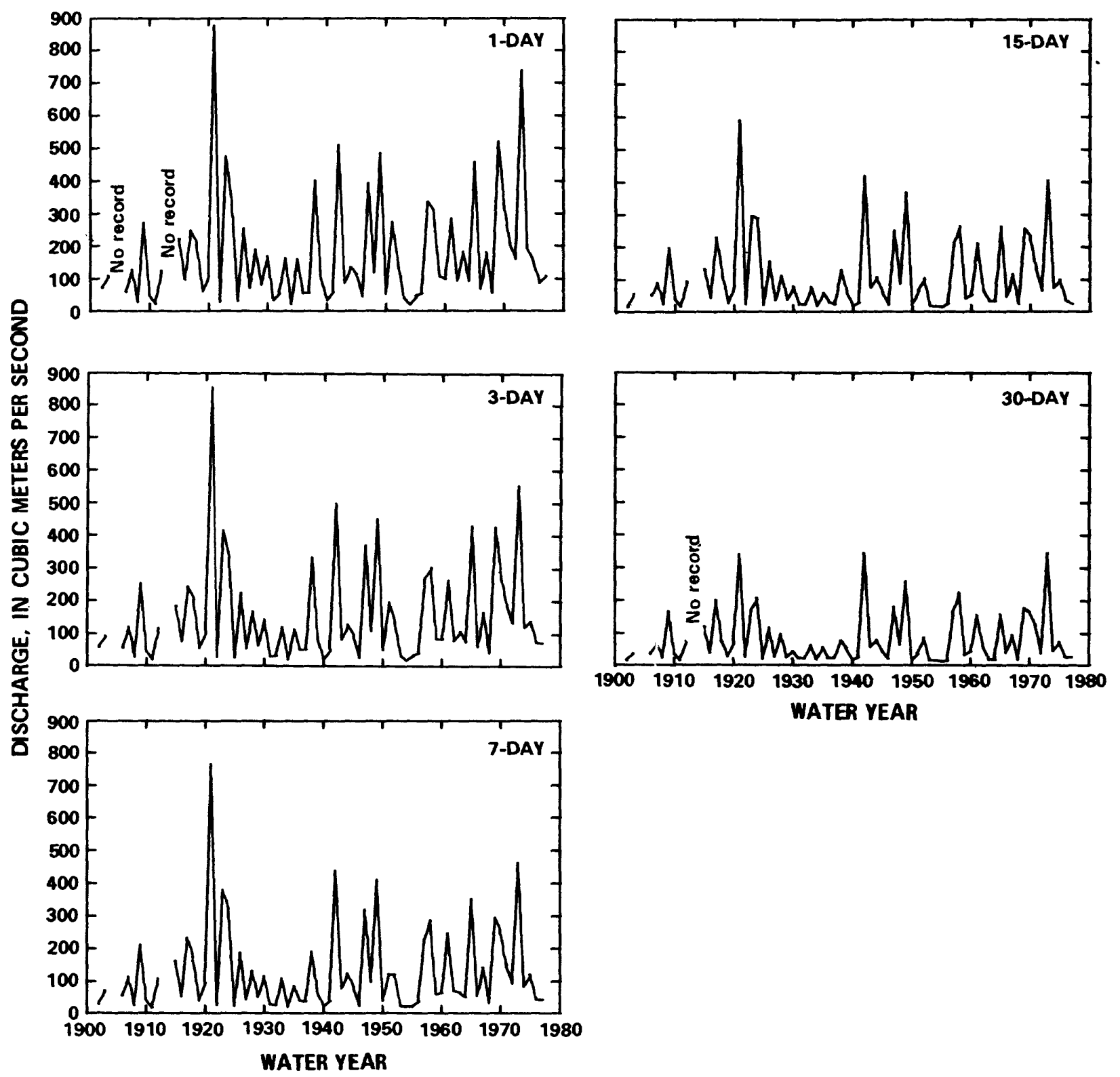

Figure 21.--Mean 1-, 3-, 7-, 15-, and 30-day high flows at station 06754000 , South Platte River near Kersey, Colorado (water years $1902,1903,1906-12,1915-79$ ). 


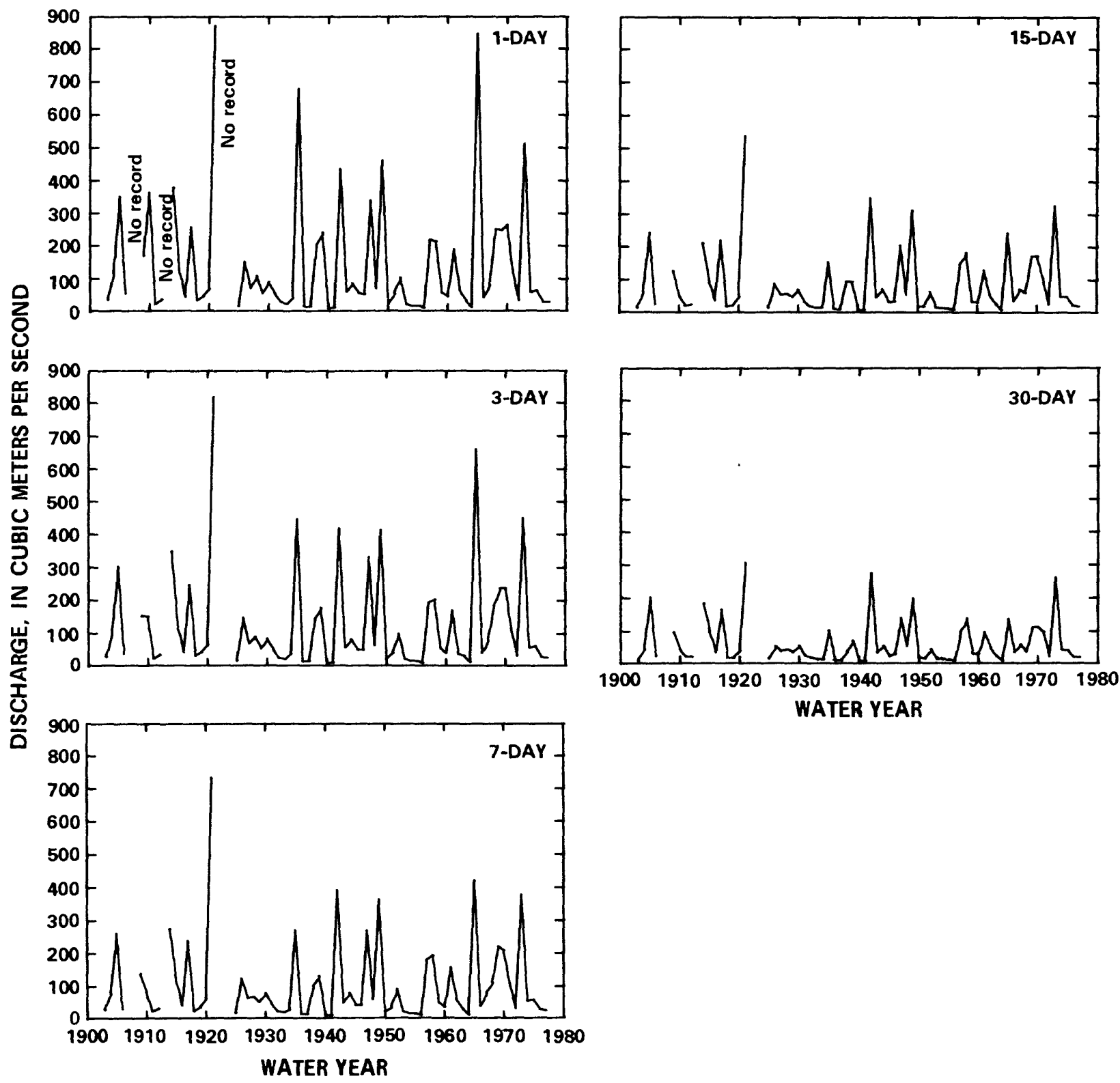

Figure 22.-- Mean 1-, j-, 7-, 15-, and 30-day high flows at station 06764000, South Platte River, at Julesburg, Colorado (water years 1903-06, 1909-12, 1914-21, 1925-79). 


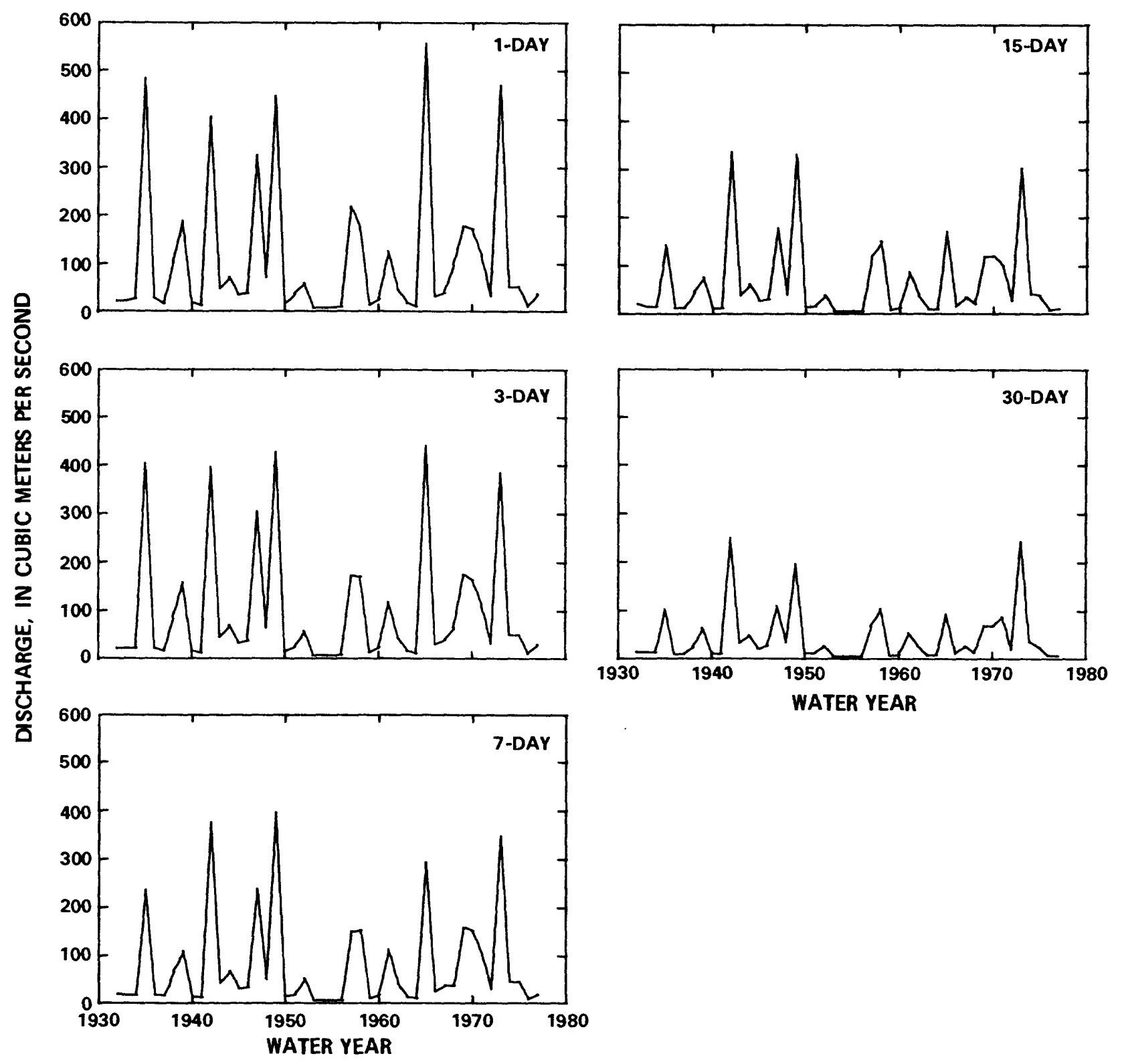

Figure 23.--Mean 1-, 3-, 7-, 15-, and 30-day high flows at station 0676550C South Platte River at North Platte, Nebraska (water years 1932-79). 


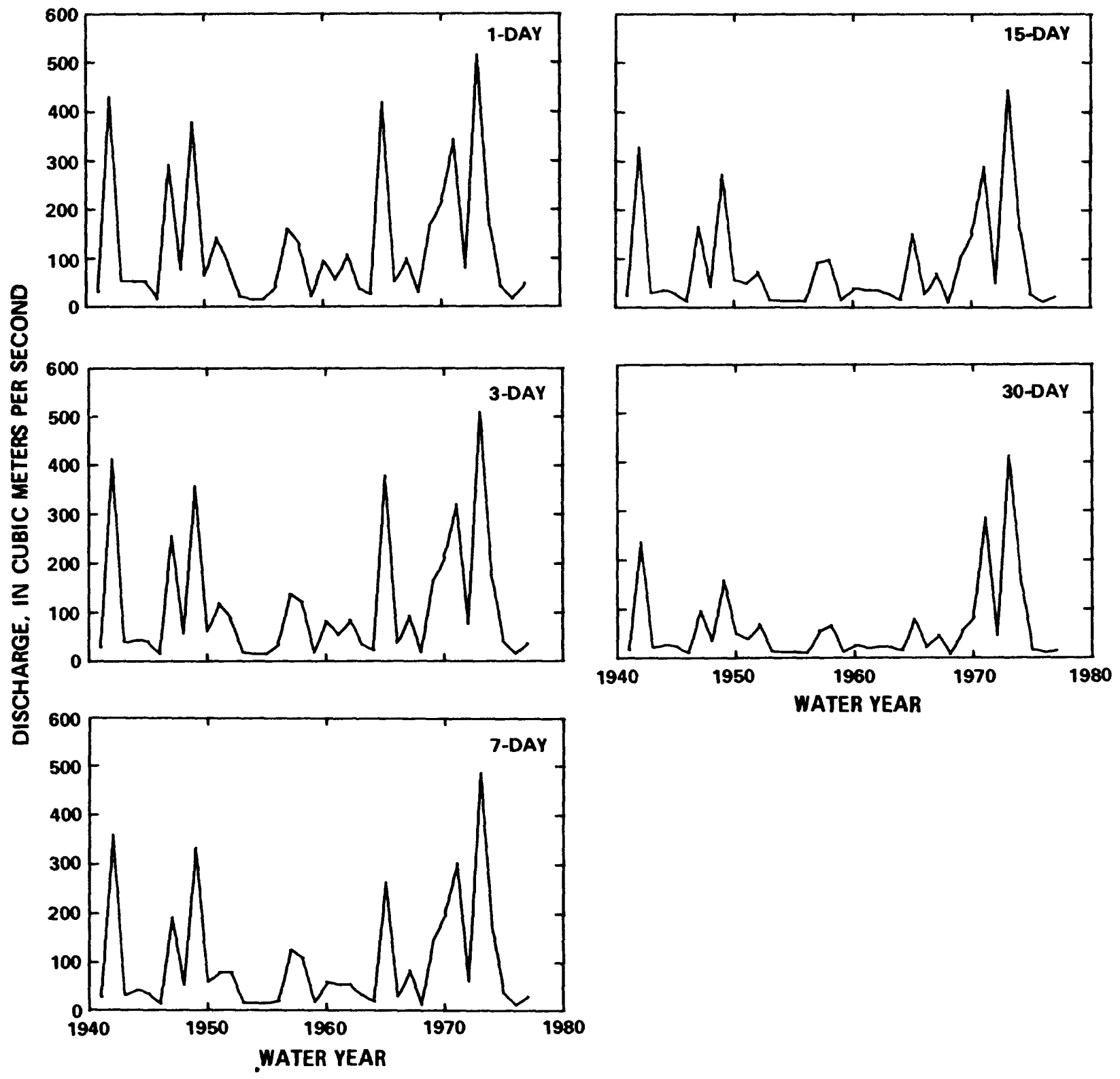

Figure 24.--Mean 1-, 3-, 7-, 15-, and 30-day high flows at station 06766500, Platte River near Cozad, Nebraska (water years 1941-79).

37 

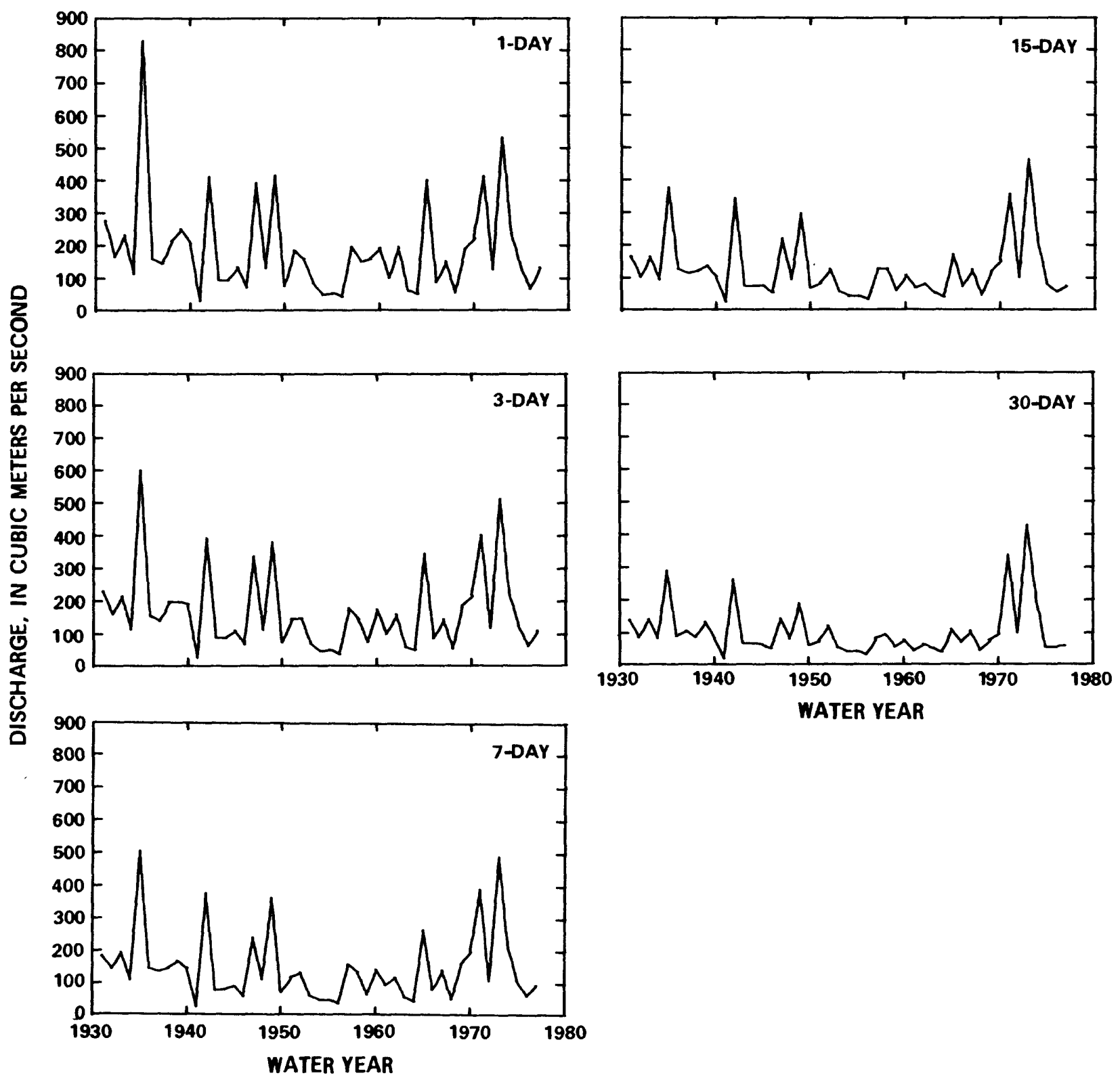

Figure 25.--Mean 1-, 3-, 7-, 15-, and 30-day high flows at station 06768000, P1atte River near Overton, Nebraska (water years 1931-79). 

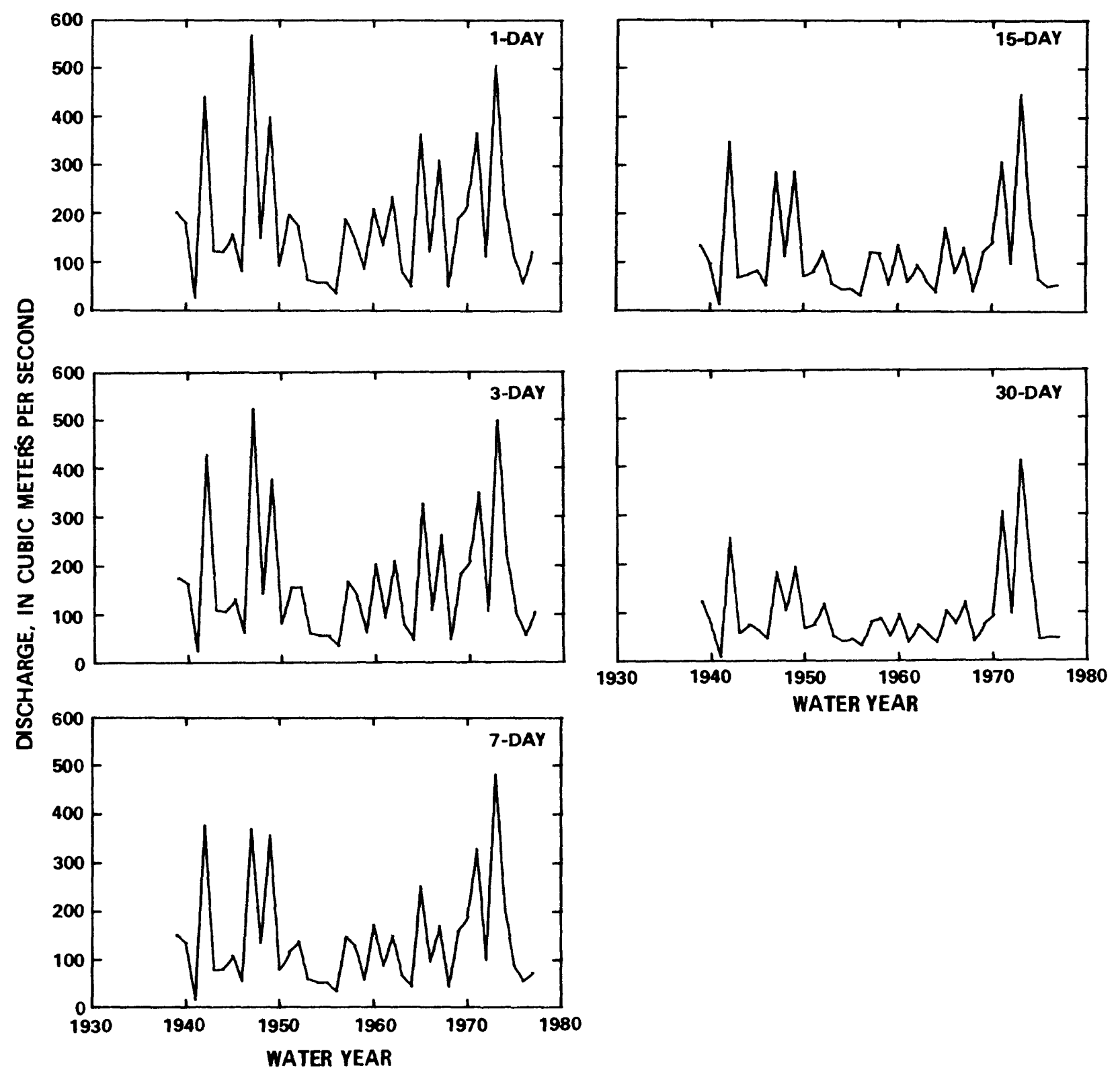

Figure 26.--Mean 1-, 3-, 7-, 15-, and 30-day high flows at station 06770000, Platte River near Odessa, Nebraska (water years 1940-79). 


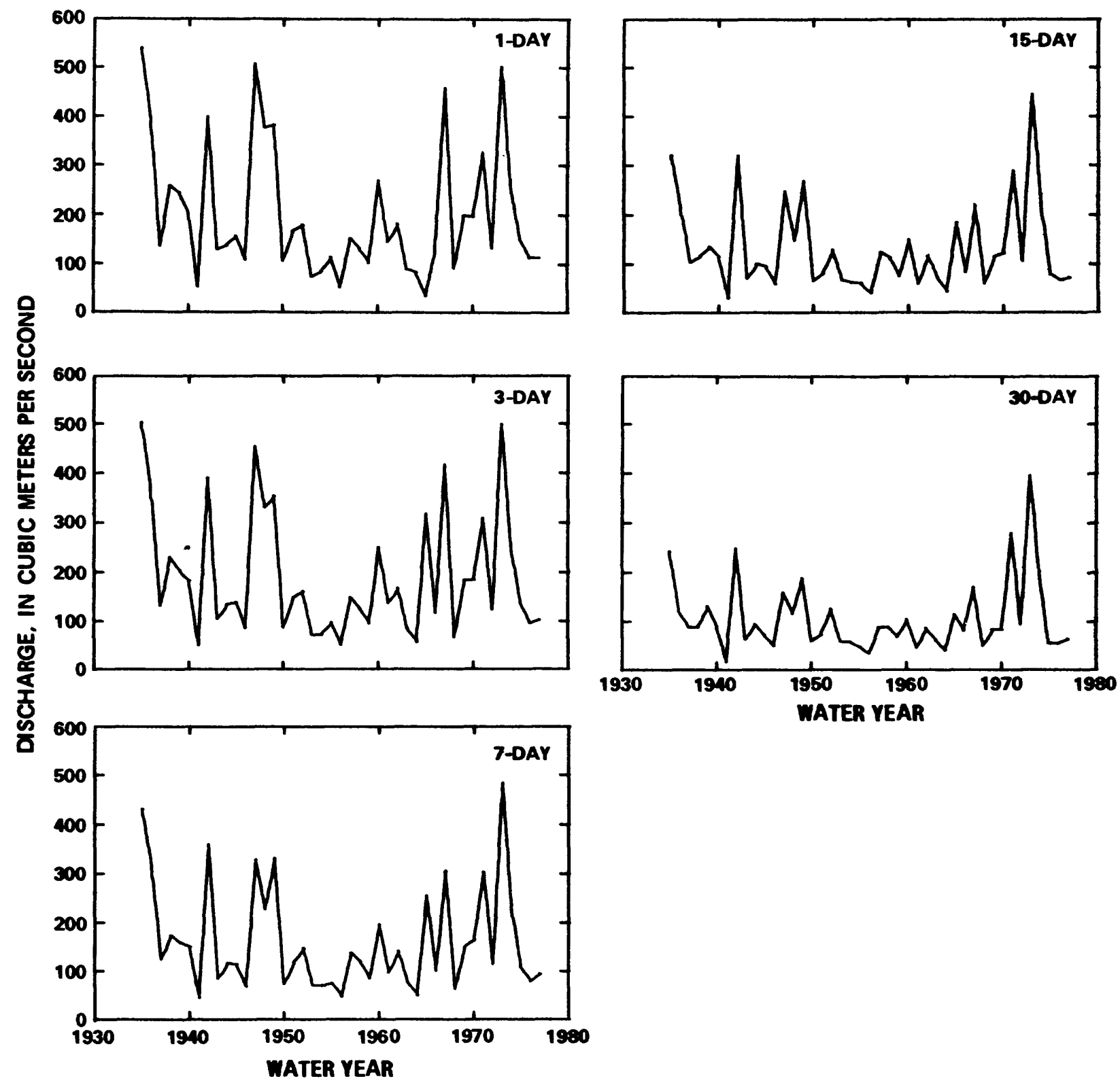

Figure 27.--Mean 1-, 3-, 7-, 15-, and 30-day high flows at station 06770500, Platte River near Grand Island, Nebraska (water years 1935-79). 


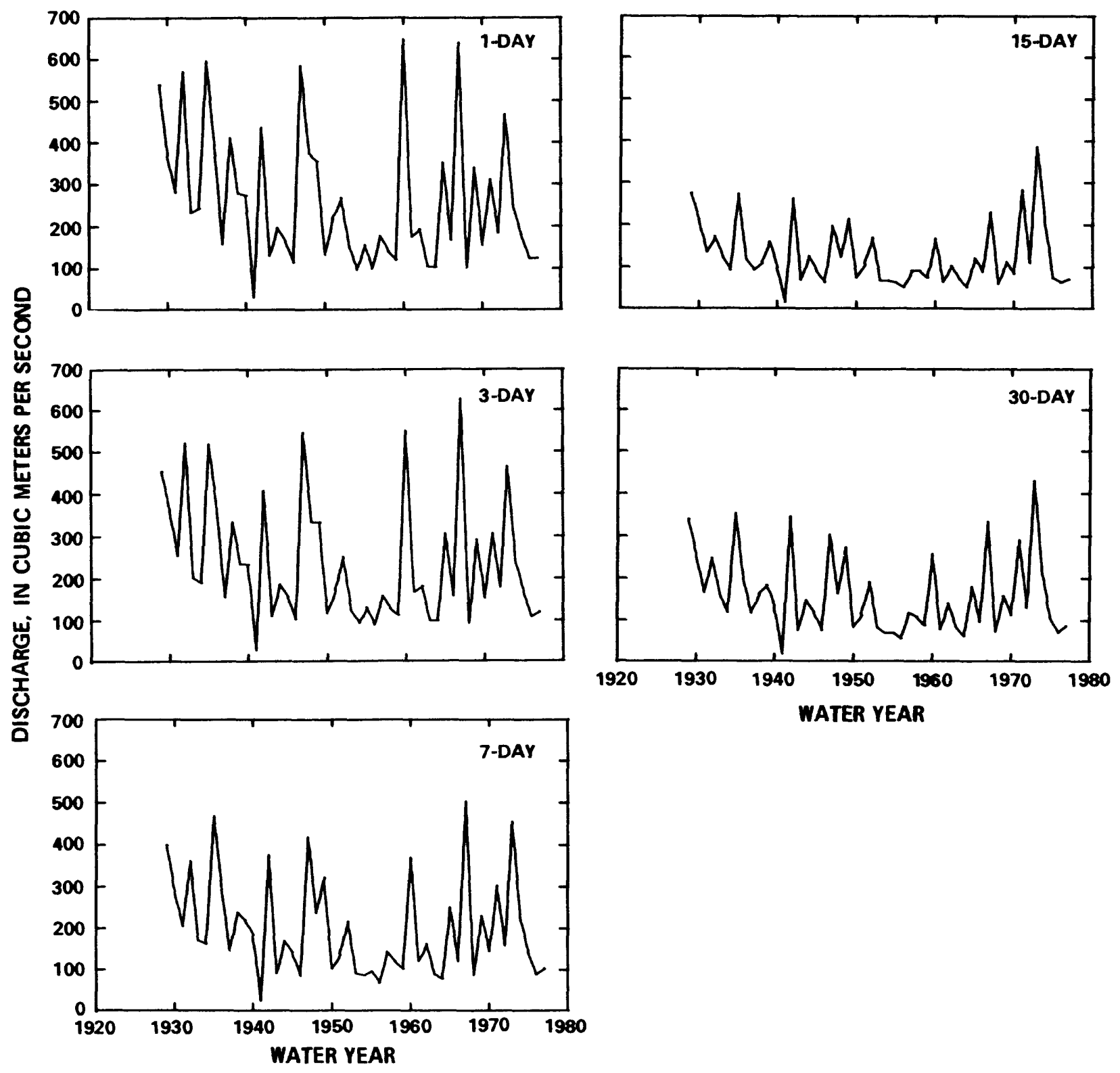

Figure 28.--Mean 1-, 3-, 7-, 15-, and 30-day high flows at station 06774000, Platte River near Duncan, Nebraska (water years 1930-79). 

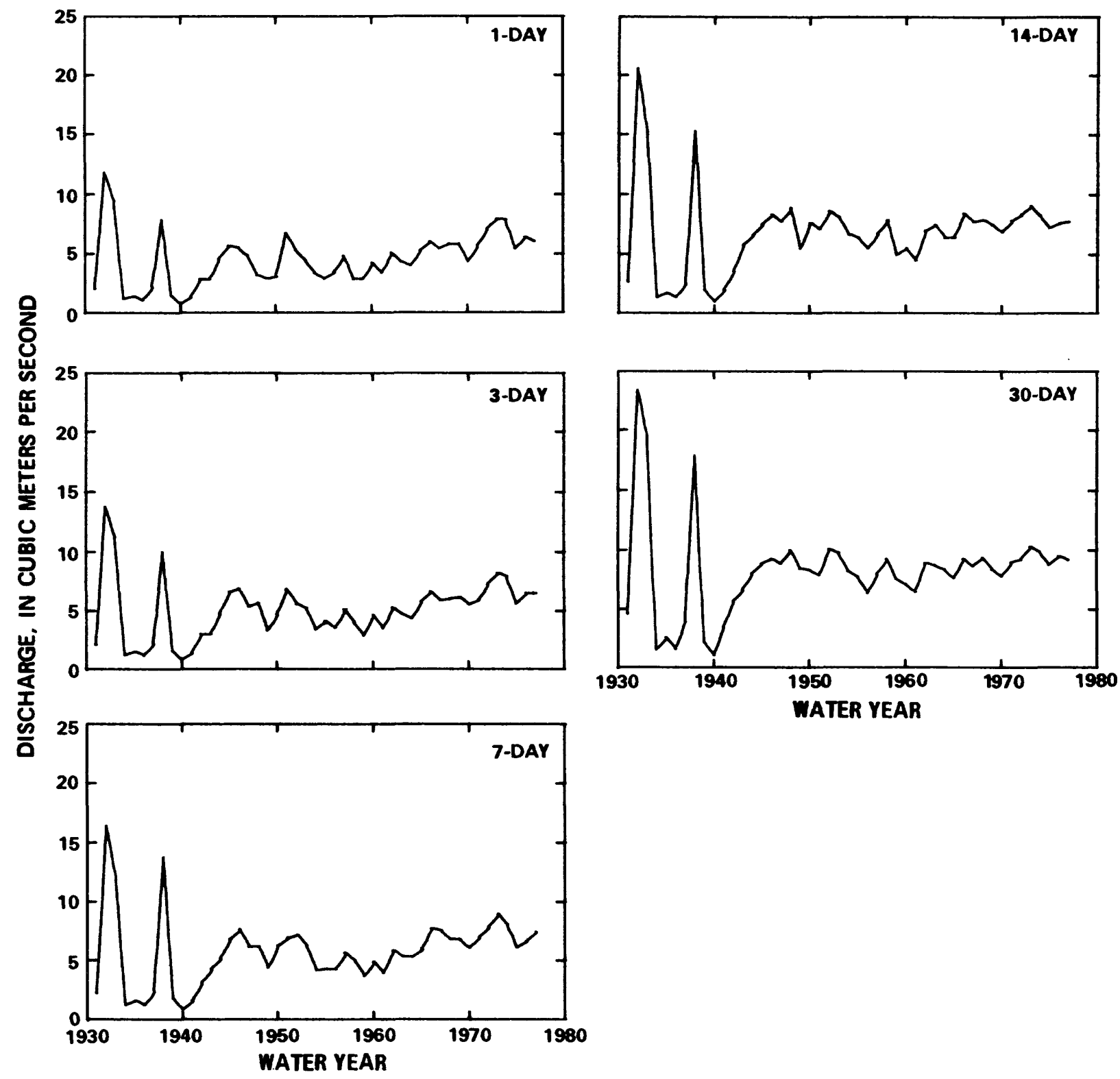

Figure 29.--Mean 1-, 3-, 7-, 14-, and 30-day low flows at station 06693000, North Platte River at North Platte, Nebraska (water years 1931-79). 

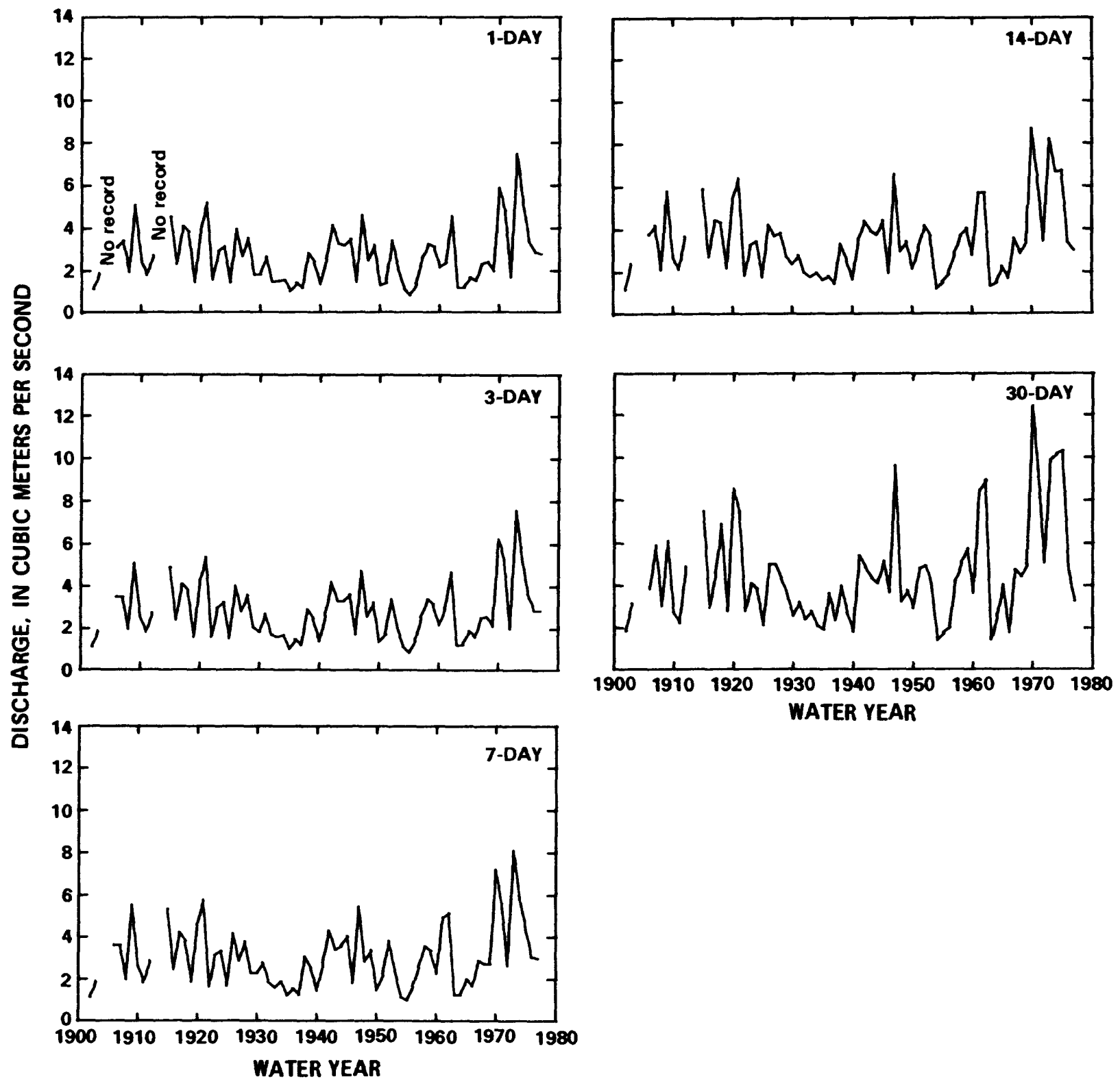

Figure 30.--Mean 1-, 3-, 7-, 14-, and 30-day low flows at station 06754000, South Platte River near Kersey, Colorado (water years $1902,1903,1906-12,1915-79$ ). 


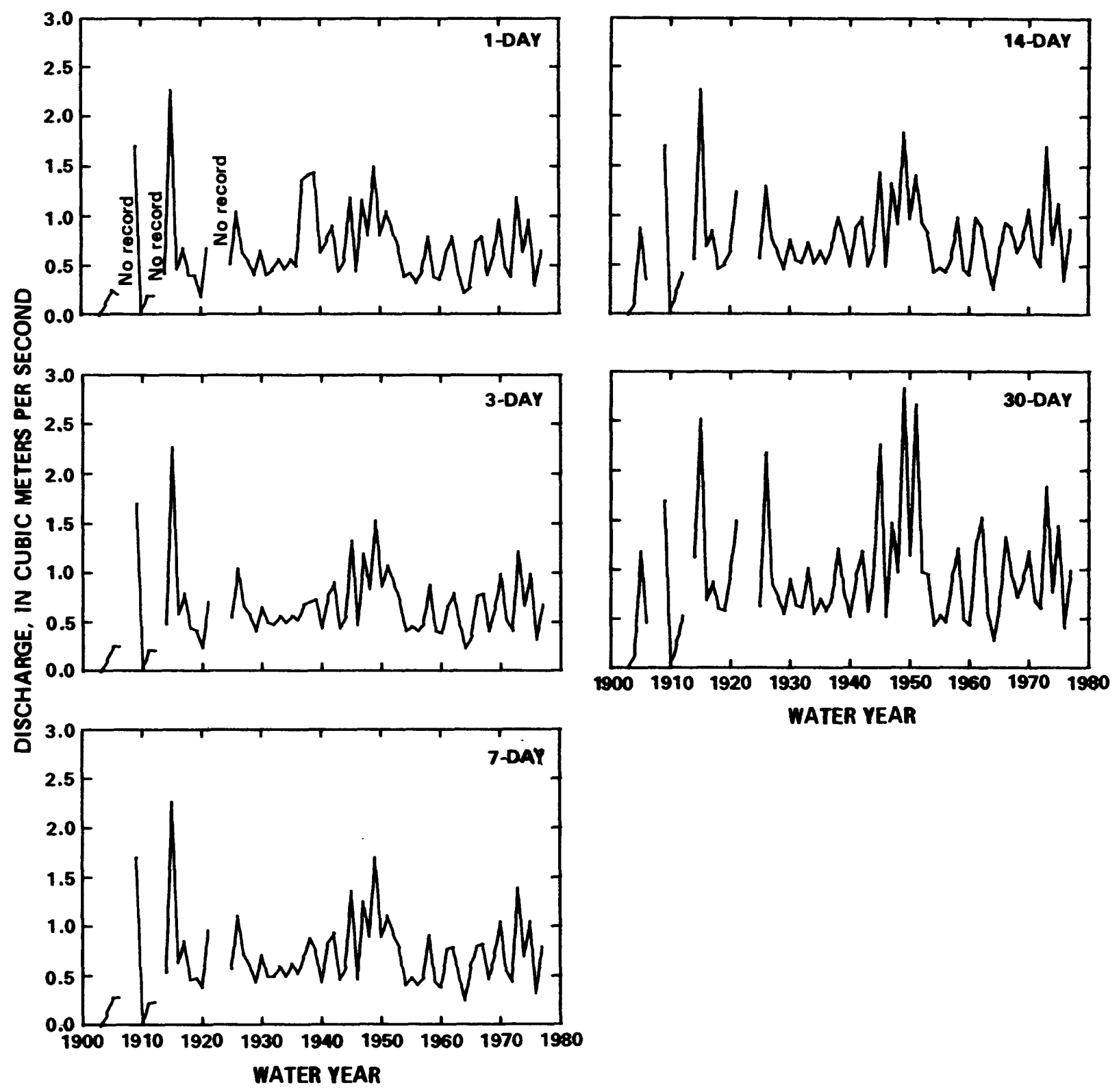

Figure 31.-- Mean 1-, 3-, 7-, 14-, and 30-day low flows at station 06764000, South Platte River at Julesburg, Colorado (water years 1903-06, 1909-12, 1914-21, 1925-79). 

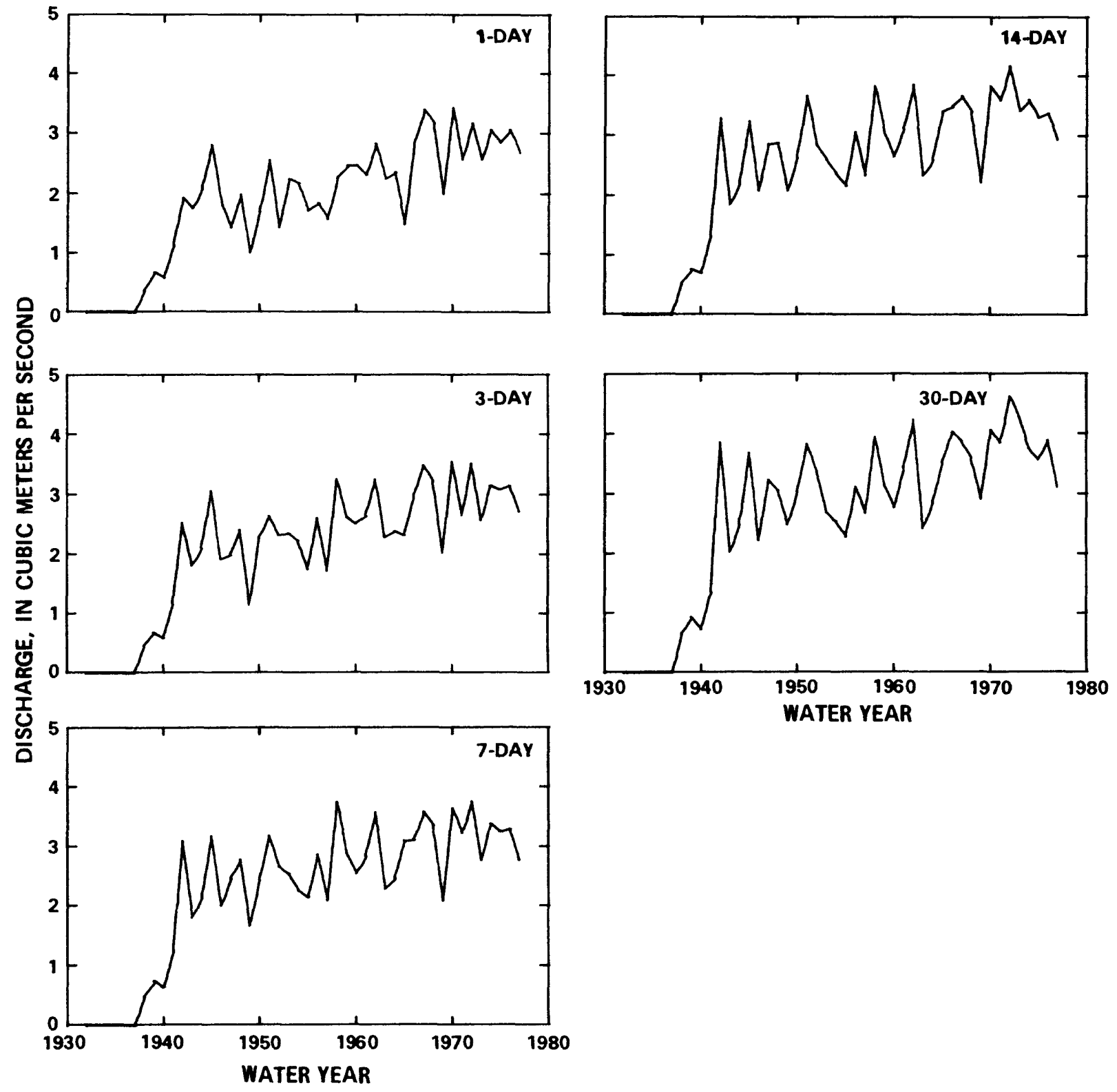

Figure 32.--Mean 1-, 3-, 7-, 14-, and 30-day low flows at station 06765500, South Platte River at North Platte, Nebraska (water years 1932-79). 

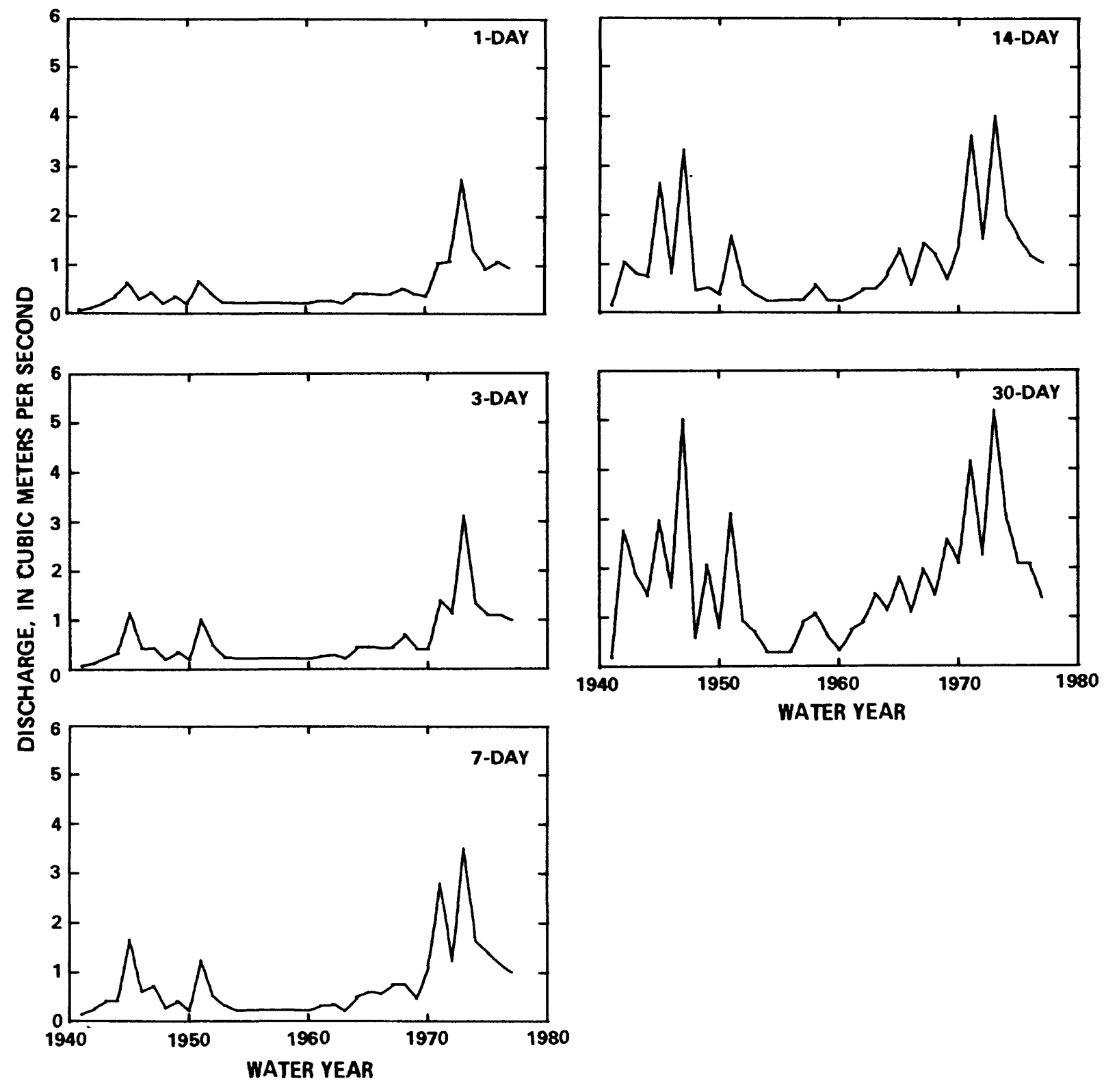

Figure 33.--Mean 1-, 3-, 7-, 14-, and 30-day low flows at station 06766500, P1atte River near Cozad, Nebraska (water years 1941-79). 


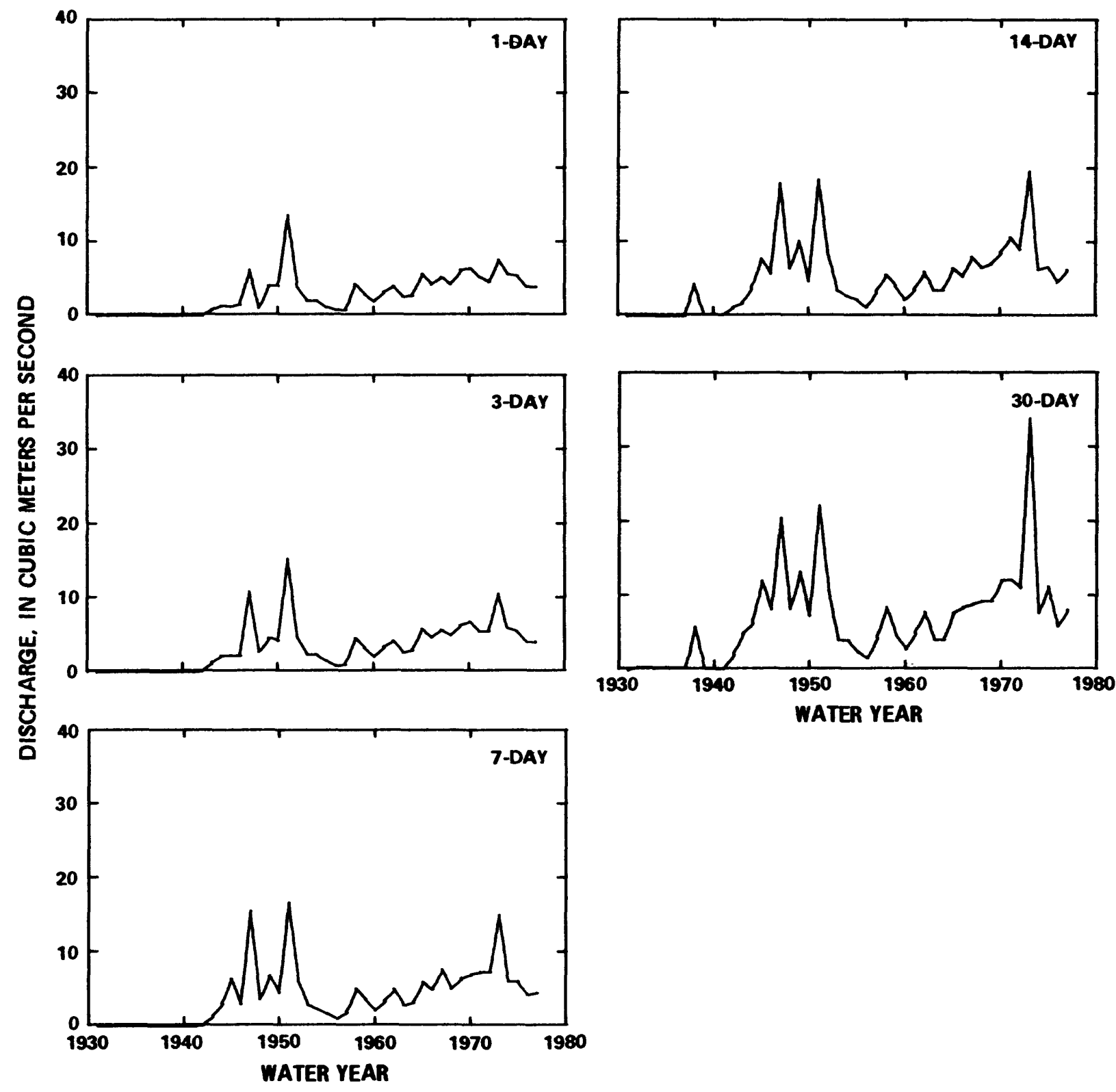

Figure 34.--Mean 1-, 3-, 7-, 14-, and 30-day low flows at station 06768000, Platte River near Overton, Nebraska (water years 1931-79). 

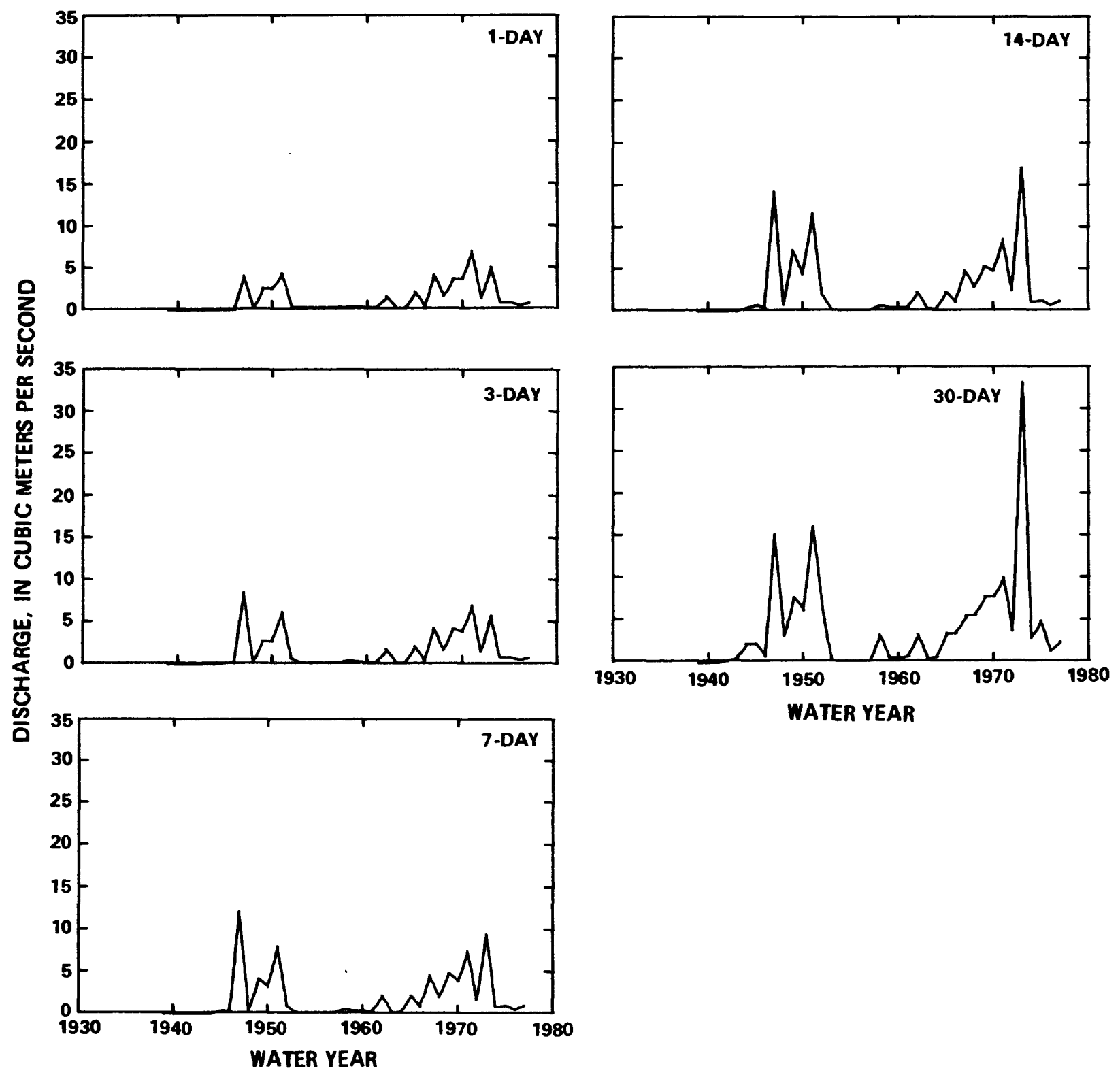

Figure 35.--Mean 1-, 3-, 7-, 14-, and 30-day low flows at station 06770000, Platte River near Odessa, Nebraska (water years 1940-79). 

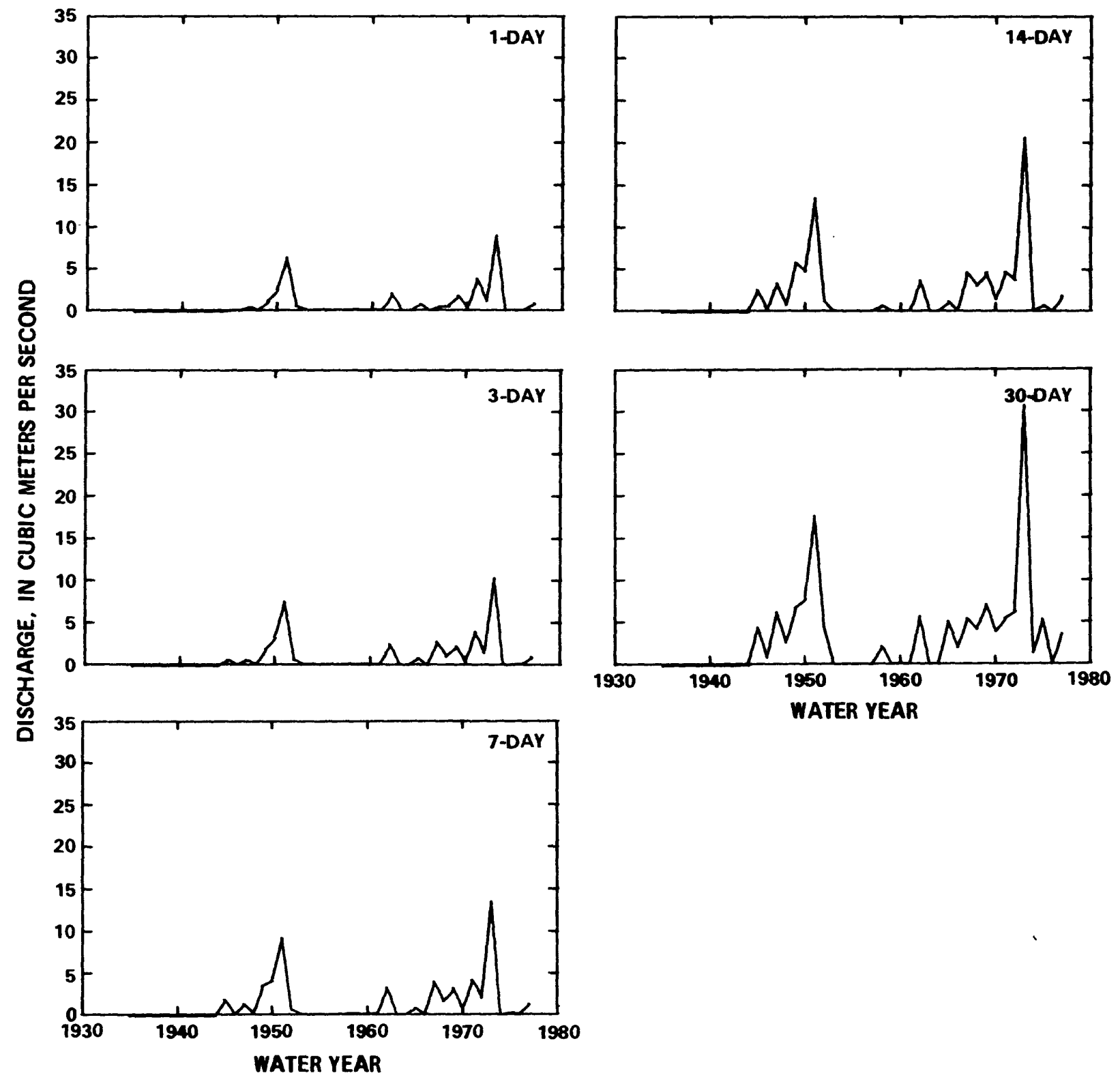

Figure 36.--Mean 1-, 3-, 7-, 14-, and 30-day low flows at station 06770500, Platte River near Grand Island, Nebraska (water years 1935-79). 


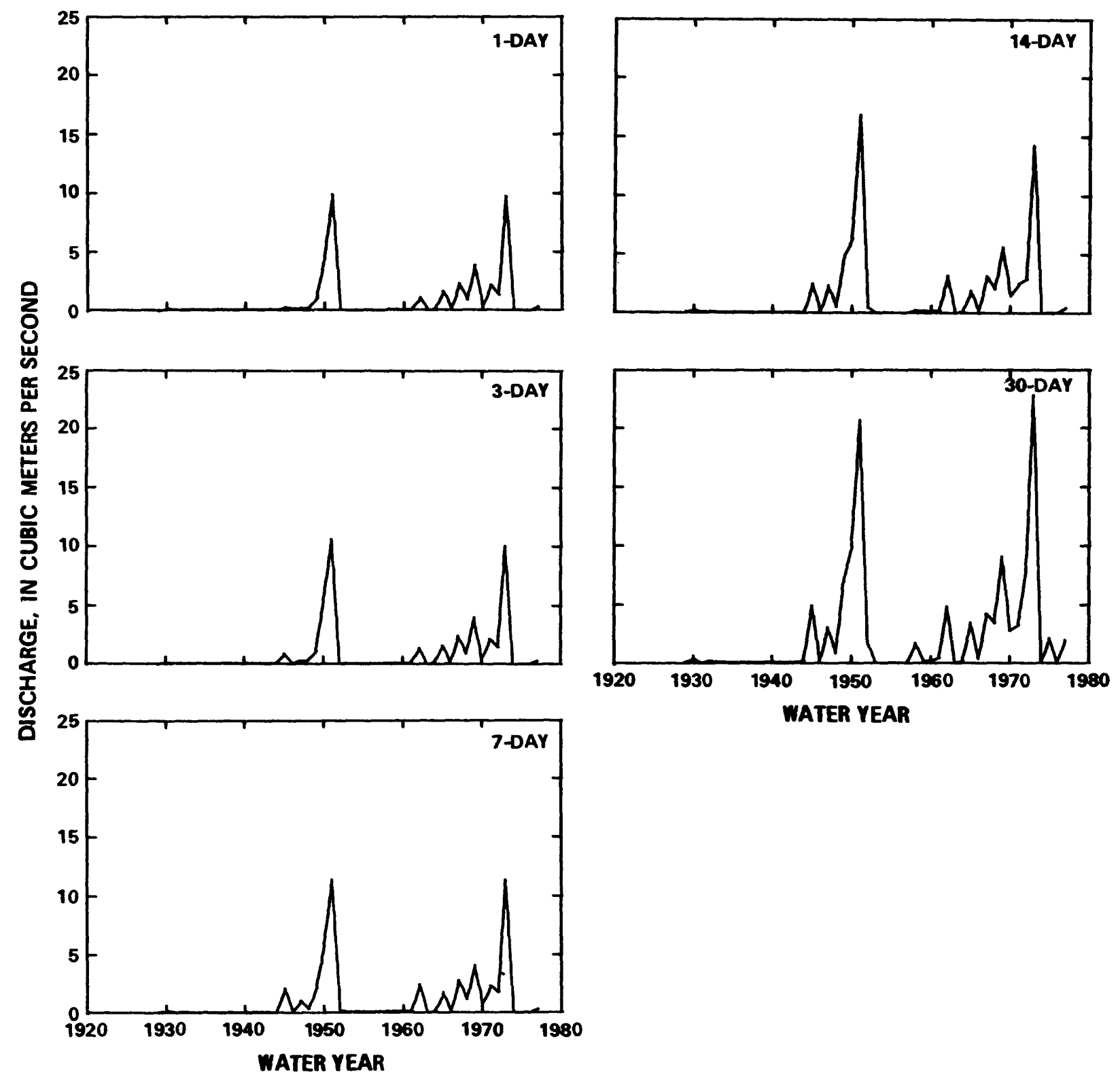

Figure 37.--Mean 1-, 3-, 7-, 14-, and 30-day 1ow flows at station 06774000, Platte River near Duncan, Nebraska (water years 1930-79). 
shows no change in low flows. The Platte River near Odessa, Grand Island, and Duncan, Nebraska, shows a slight increase in low flows, but the change is not as pronounced as at the upstream stations.

\section{Statistical Analyses}

Statistical analyses were performed on annual mean flow and peak flow for the previously mentioned six sites to make the following determinations:

1. The significance of major developments along the rivers that would cause abrupt changes in the time series of annual mean flow and annual peak flow and,

2. The significance of developments that would show a more gradual change or time trend in annual peak flow and annual mean flow.

The on1y major development along the Platte River system that was suspected to cause a drastic modification in the time series of the flow statistic was the construction of Kingsley Dam and subsequent formation of Lake McConaughy. Construction of coffer dams, diversions, and off-stream storage for Kingsley Dam was begun about 1935 (Shaffer, 1976), so the period of record for all sites was divided into two time frames, when available, of pre-1935 and post-1935. Water year 1935 was included in the post-1935 time frame.

The significance of any major development causing abrupt changes in the time series of the flow variables, was determined by an analysis of covariance (Riggs, 1969; Kleinbaum and Kupper, 1978). In this analysis, logarithms of the flow variable were regressed against time with dummy variable parameters as additional independent variables. The dummy variable parameters included a dummy variable value of 1 for the pre-1935 period and a dummy variable value of 0 for the post-1935 period. If the partial $F-$ statistics of the regression indicated that the inclusion of the dummy variable parameters was statistically significant to the regression, then the regression was analyzed considering the separate periods for time trend analyses. The level of significance used was the 5-percent level.

The trend analysis was performed to determine any gradual change of the flow variable with time. The trend analysis was simply a regression of the logarithm of the flow variable against time, for either the total period or for each individual period. Whether one or two time periods were analyzed was determined from the results of the analysis of covariance. If the hypothesis that the construction of Kingsley Dam had no effect on the respective flow variable is not rejected (corresponding to the $F$-statistics of the analysis of covariance being insignificant at the 5-percent 1eve1), then a single trend line would be obtained for the entire period of record. If, however, this same hypothesis is rejected, then a trend line would be determined for the period up to 1935 in addition to one for the period after 1935. 
It is important to note that the determination of the trends is made only for comparative purposes, and not for estimations of the particular flow variable to be made at any site. A statistical summary of the covariance analyses is shown in table 5. The values in the table are applicable only for comparing the significant changes in hydrology between sites or between periods or to notice any overall trend in flow variables for any site.

\section{Mean Flows}

Annual mean flows for the six sites are shown in figures 38 through 43. The North Platte River at North Platte, Nebraska (fig. 38), had a decrease in annual mean flows during the mid-1930's. From the analysis of covariance results of table 5 , it can be seen that there is a definite shift in the time series for mean flows in the North Platte around 1935. The large Fstatistic indicates that a model of mean flow versus time should be broken into the pre-1935 and post-1935 time periods. However, the slope for each time period is not significantly different from zero; therefore, there was no significant trend in mean flow at this station during the period before 1935 or during the period after 1935. Because regressions of mean discharge versus time for the pre- and post-1935 periods show no change in mean flow with time for each period, an alternative test for indicating the difference in the respective populations would be a simple t-test on the means for each period.

The South Platte River stations (figs. 39 through 41) indicate very little change in the annual mean flow with time, even with the extensive development upstream. The absence of change indicated by visual inspection of the records from the South Platte River stations is verified by the analysis of covariance. The F-statistics indicate that there has been no statistically significant shift in logarithms of mean flows between the two periods, and the total period t-statistics on the regression slope parameter indicate that there was no significant trend over the entire period.

The annual mean flows for the Platte River near Overton (fig. 42) decreased abruptly during the mid-1930's. The statistical results of table 5 support this significant trend by indicating that a regression model of the logarithms of mean flow versus time for Overton need to be divided into the two specified periods. Slope parameters of the individual regressions are not significantly different from zero.

The logarithms of the mean flows for the Platte River near Grand Island (fig. 43) show an increasing trend for the entire period of record, which began after 1935. This increase probably was unduly affected by the high flow water years 1971-74.

Monthly mean flows for the period of record for April through September are shown in figures 44 through 47 . These months were chosen because they encompass the critical growth period for vegetation as defined by the U.S. 


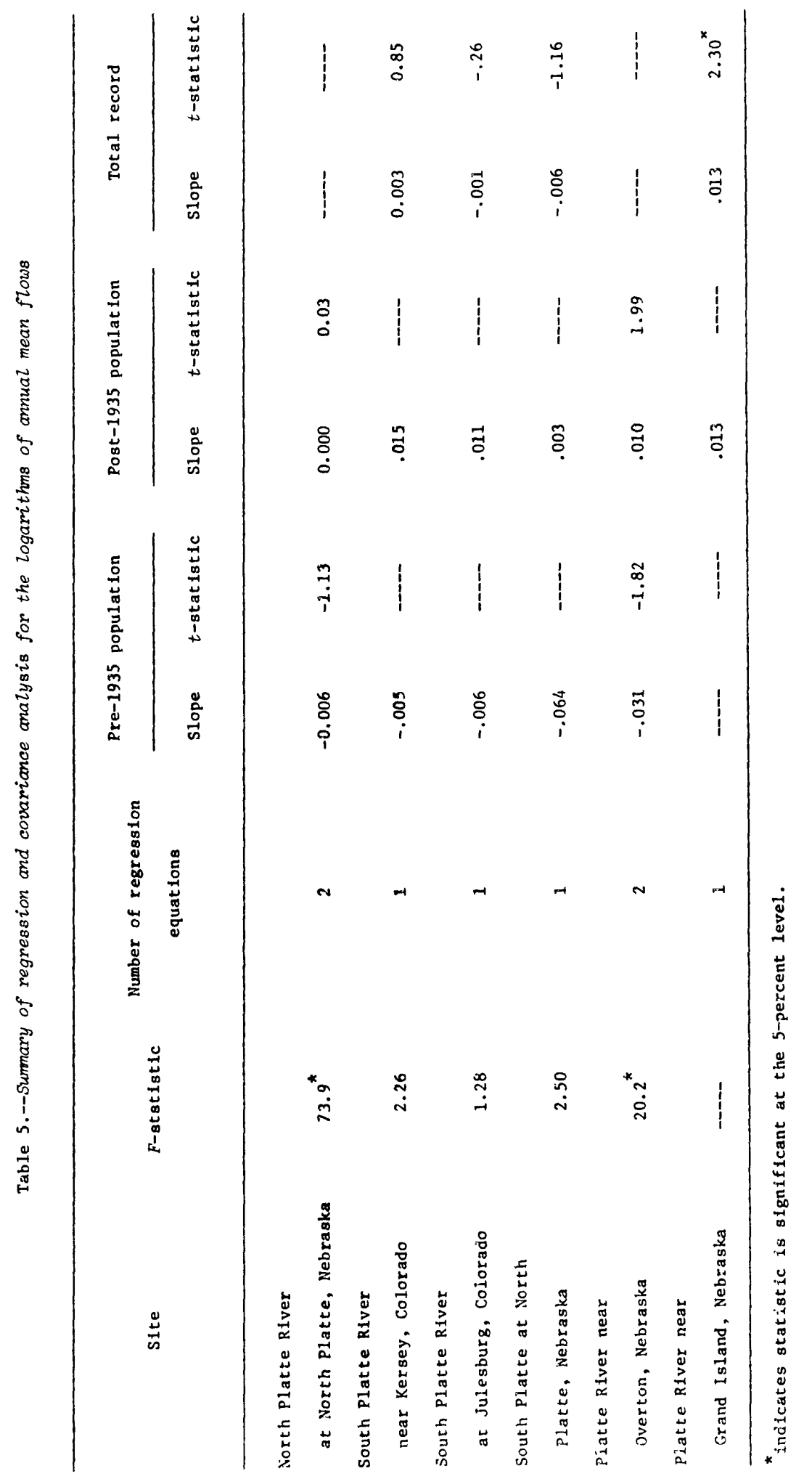




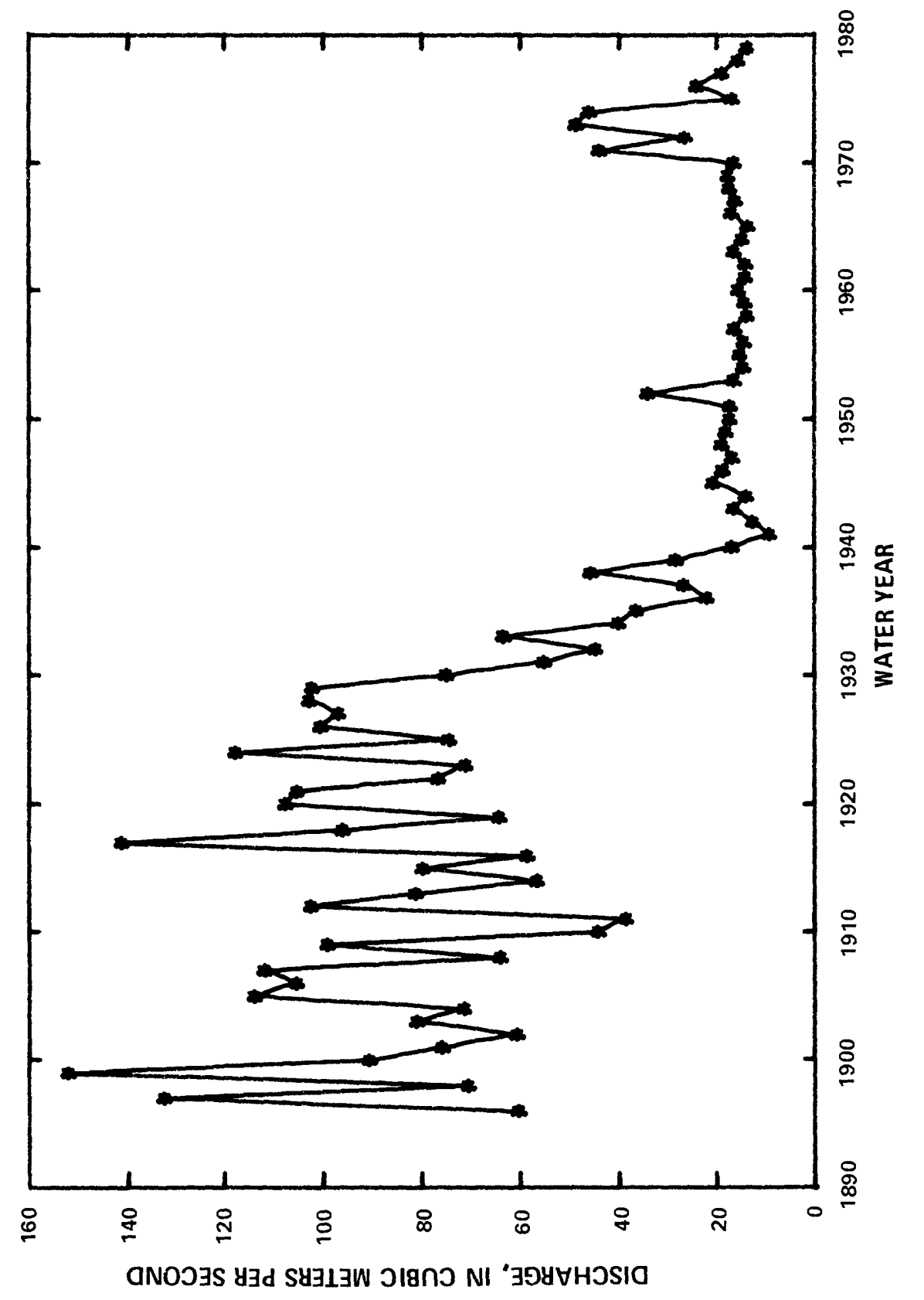

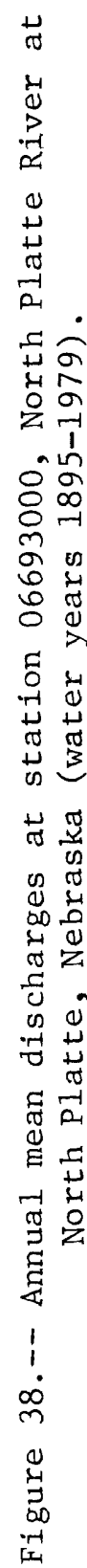




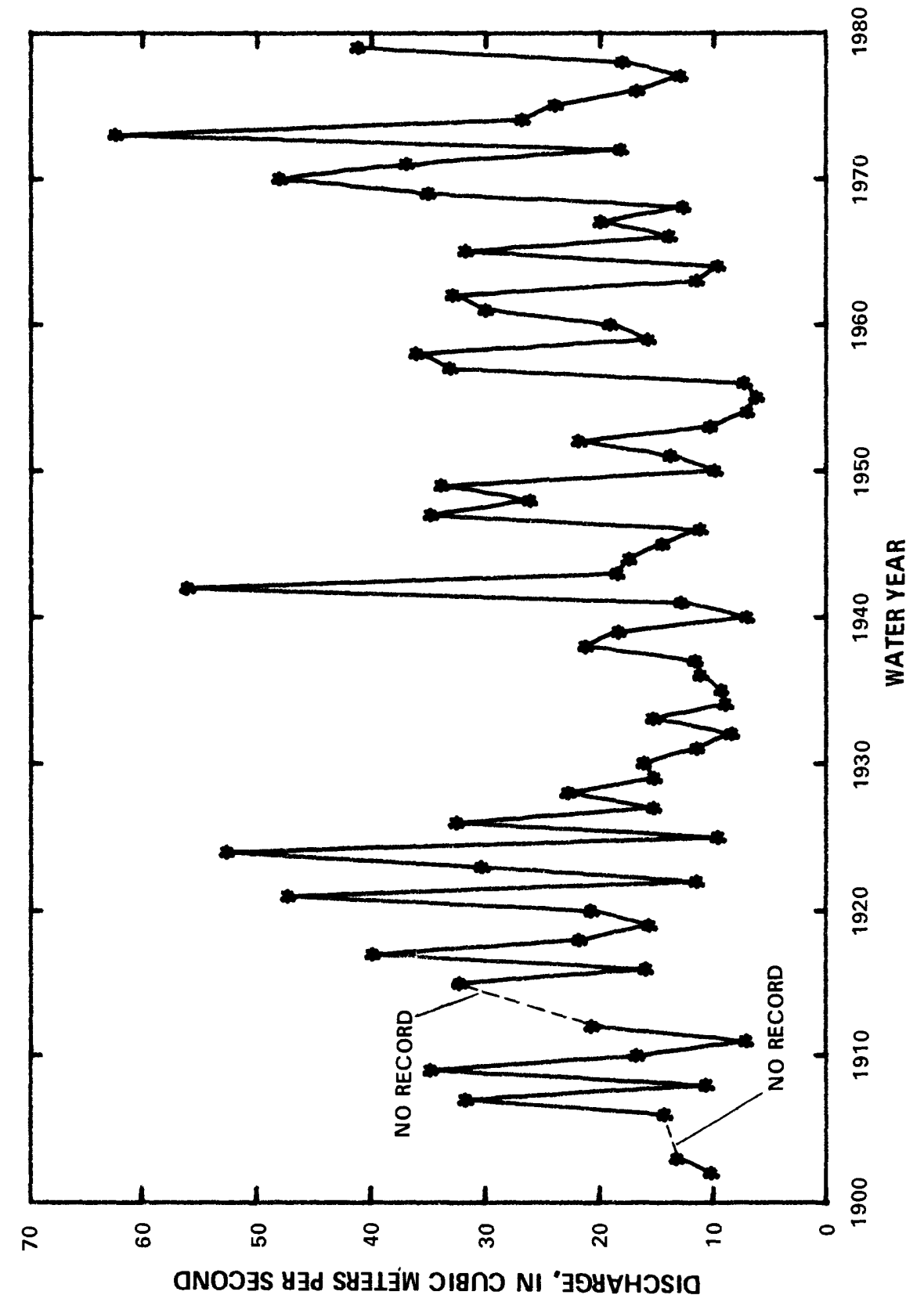

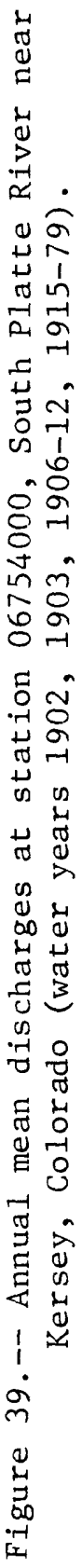




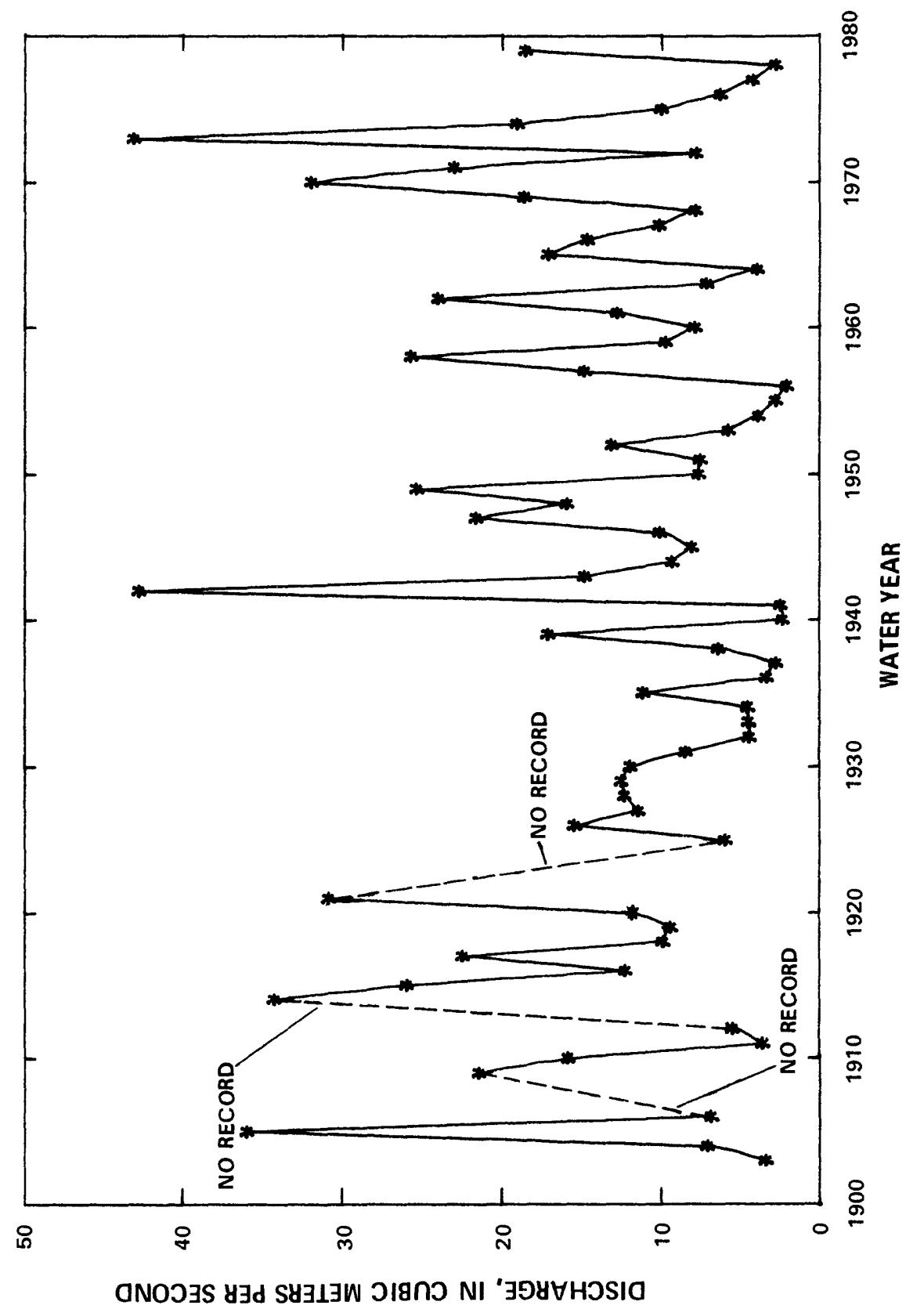

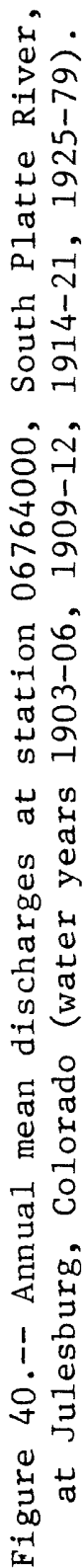

ANOJ y 


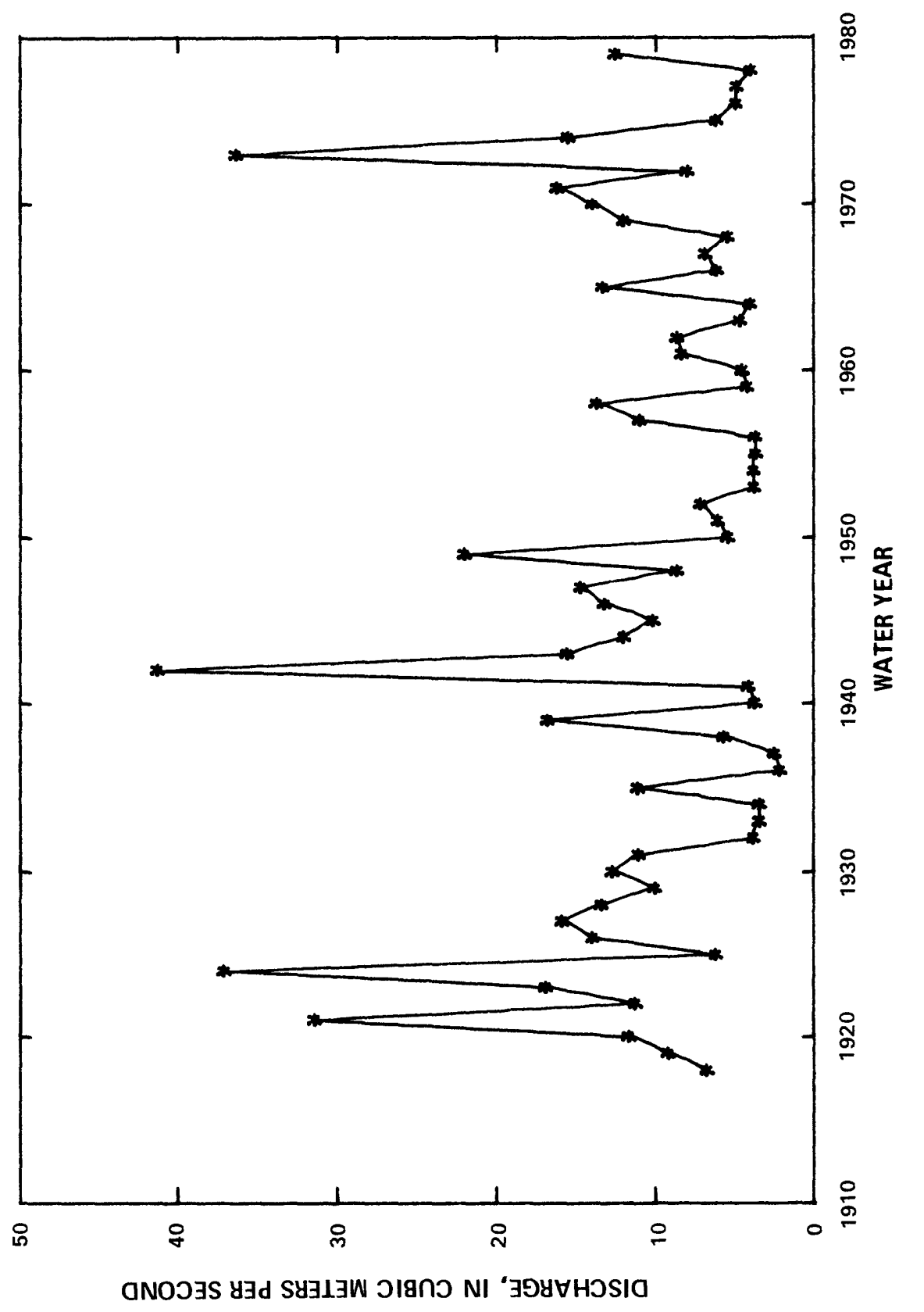

+
0
0
0
0
0

$+$

D.

I.

วิ

थ 1

요

ㅇำ-

กู

ถู่

品

ธี ชิ

出

先 3

is

$+\pi$

崩

os

000

学

帘

in

坵出

ᄃ

क

站

겅ㅇㅇ

䓠

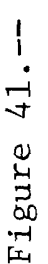

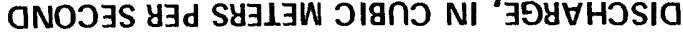




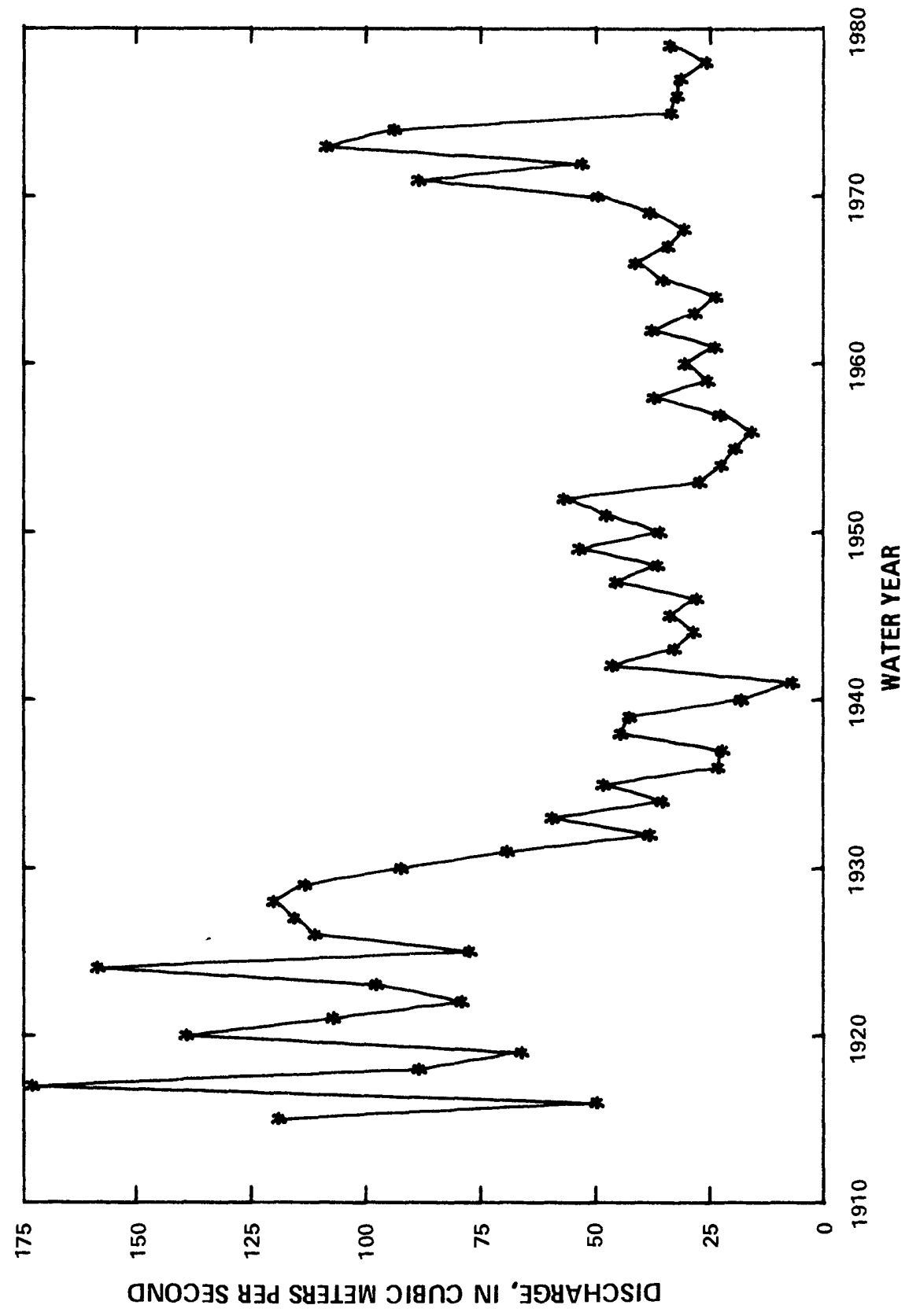

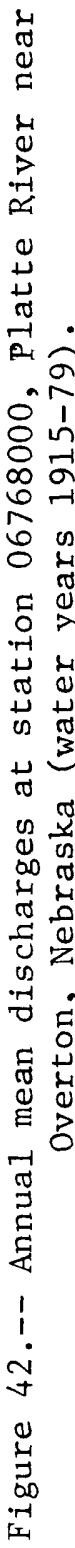

aNOJ 


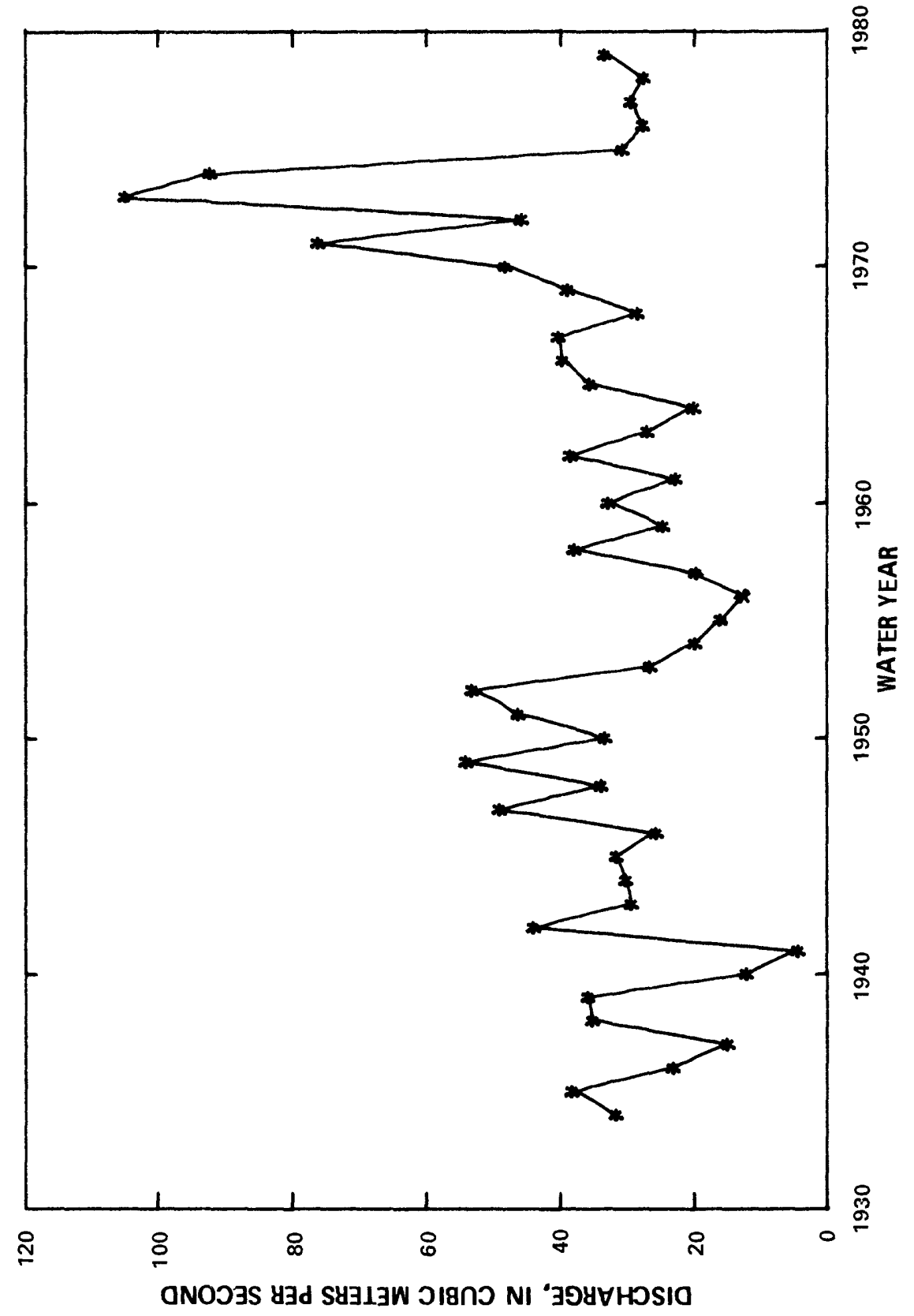

4
0
0
5
4
0
$D$
-1
01

4
0
0
01
01

盛

त्ञ

ठํ

जी

N

సิ

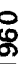

ป

E)

मैं कै

๘

क क 3

뜬

崩

on

$\int_{0}^{\pi}$

क ti

完

o

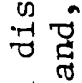

कृ का

$\stackrel{\varrho}{E} \mapsto$

- 믐

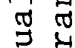

艺过

恶

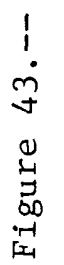

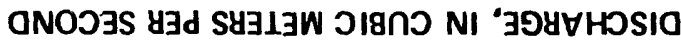




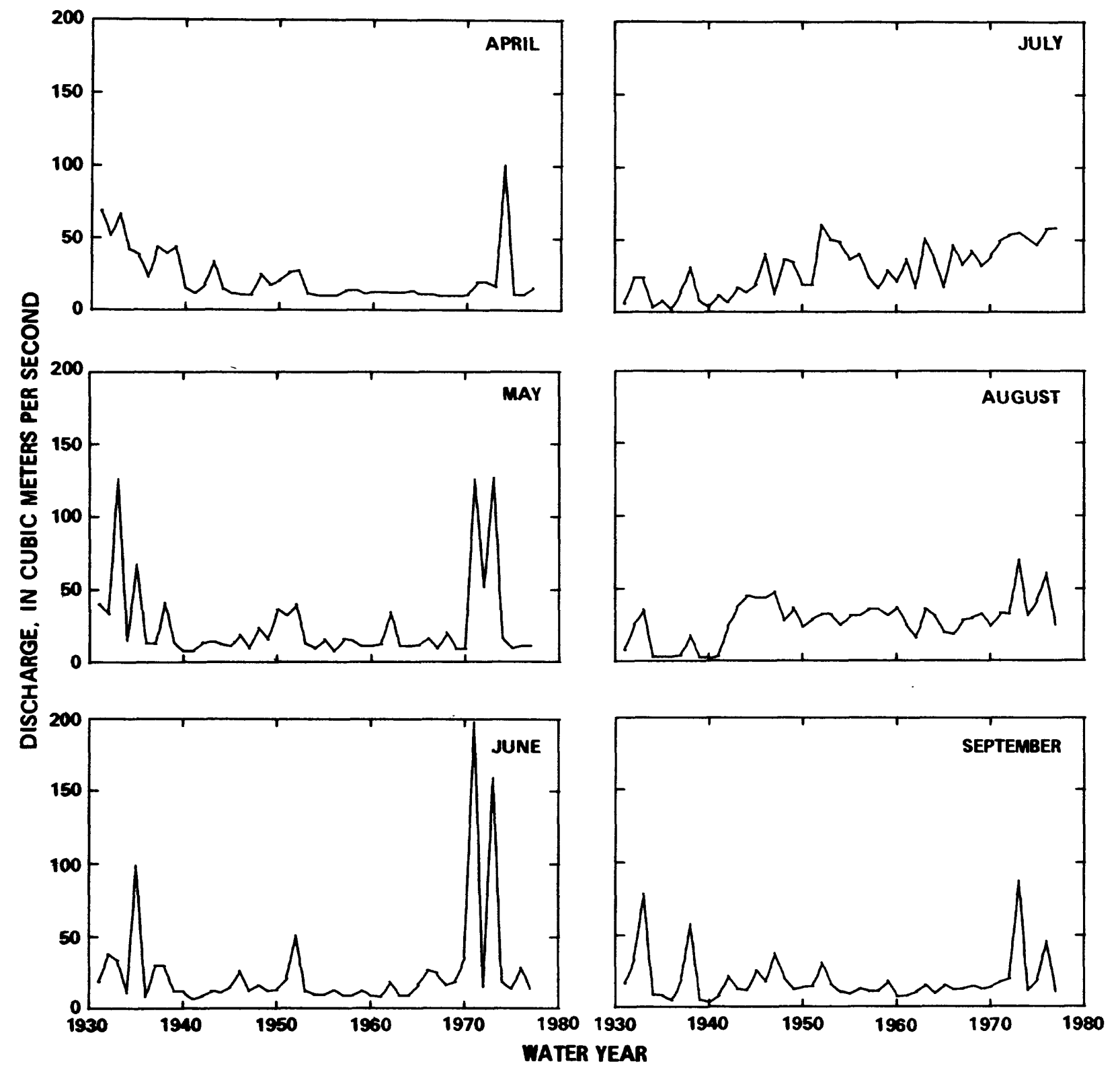

Figure 44.-- Month1y mean discharges for April through September at station 06693000, North Platte River at North Platte, Nebraska (water years 1931-78). 


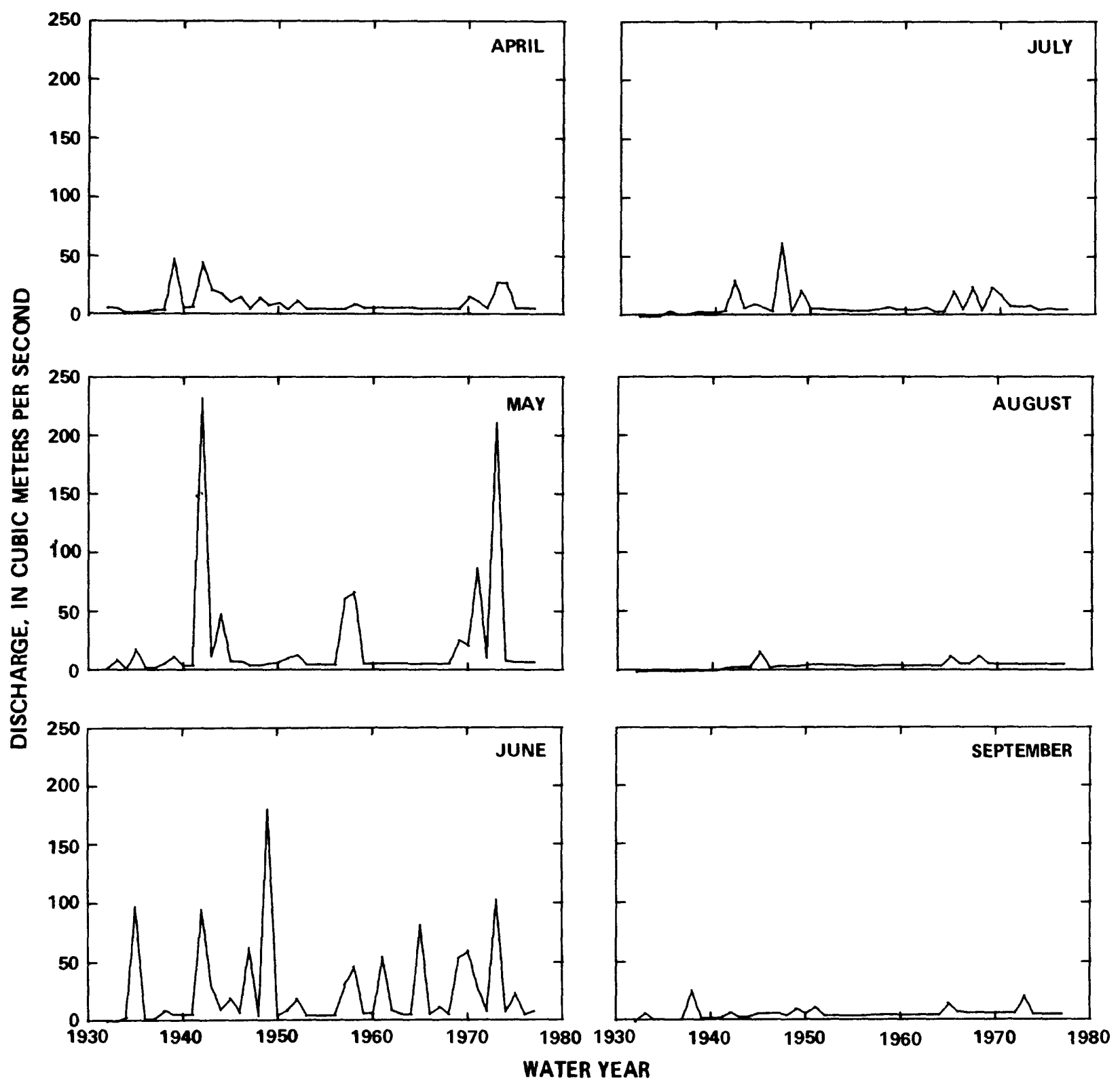

Figure 45.-- Monthly mean discharges for April through September at station 06765500, South Platte River at North Platte, Nebraska

(water years 1932-78). 


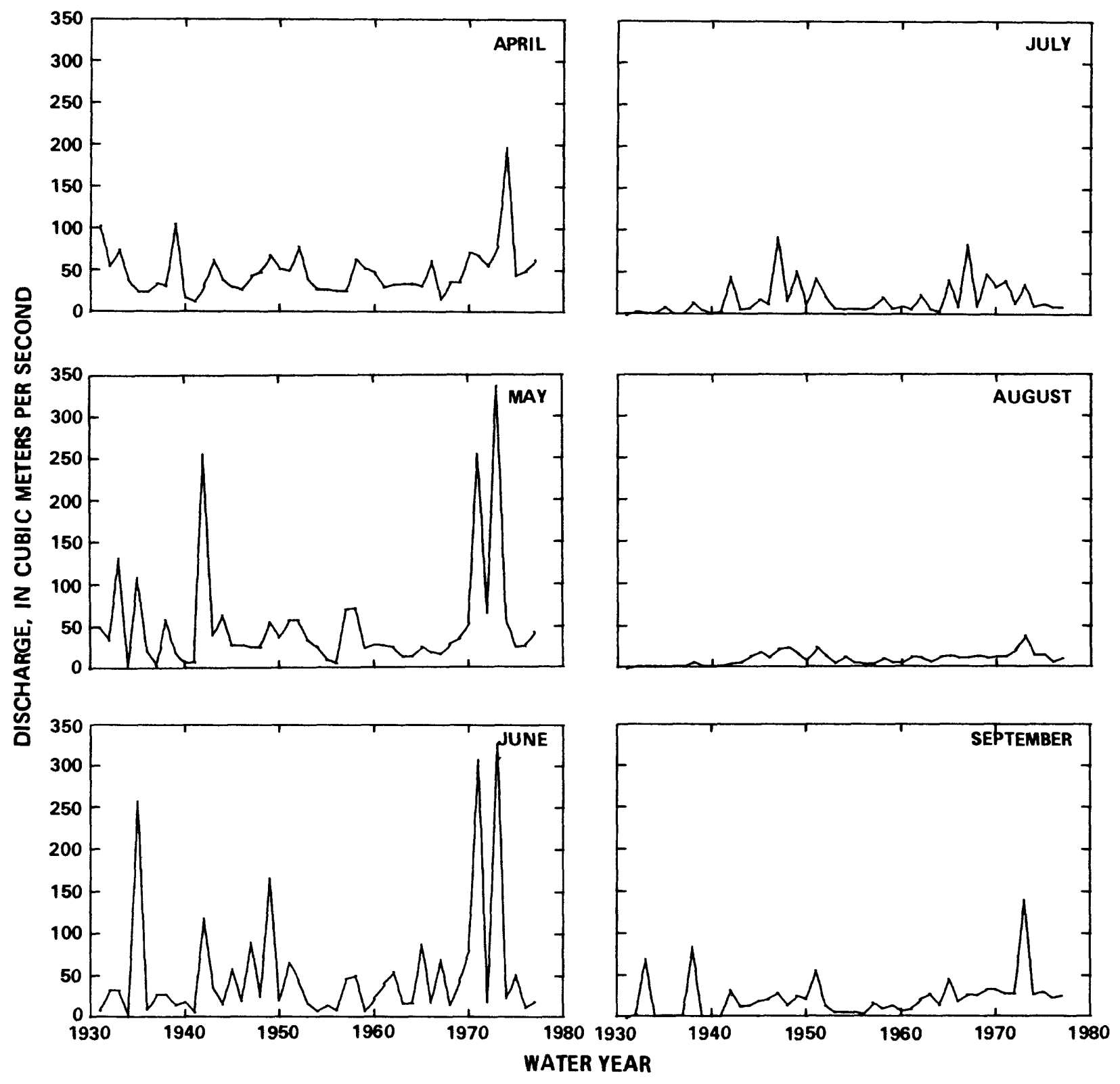

Figure 46.-- Monthly mean discharges for April through September at station 06768000, P1atte River near Overton, Nebraska (water years 1931-78). 


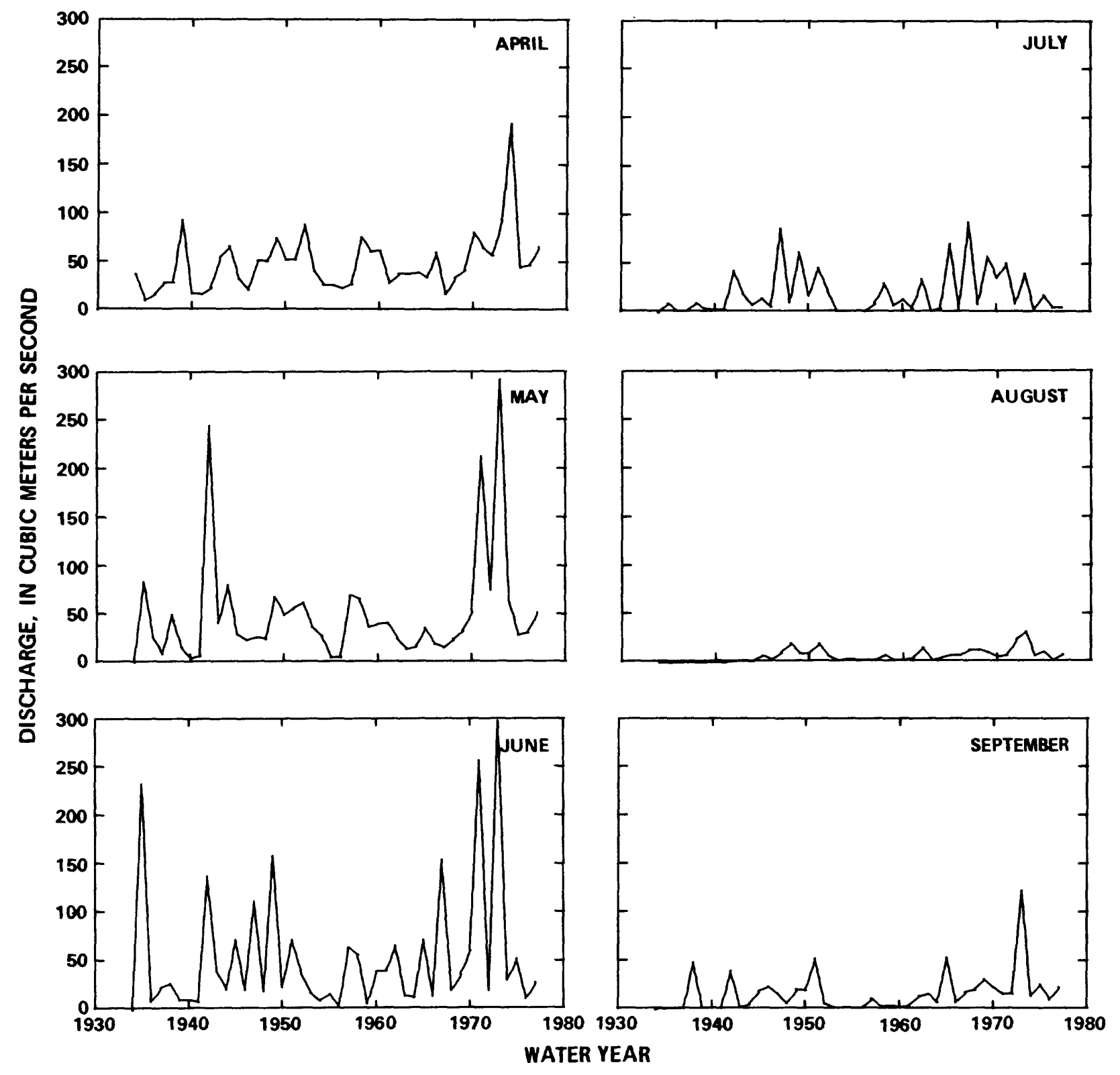

Figure 47.-- Monthly mean discharges for April through September at station 06770500 , Platte River near Grand Island, Nebraska (water years 1935-78). 
Fish and Wildlife Service. The months also include the major runoff period and irrigation season. Only four stations were used in this analysis to show the changes on the North Platte River, South Platte River, and the Platte River. in and near the critical reach.

The monthly mean flows during July and August for the North Platte River (fig. 44) indicate a marked increase beginning about 1945. These are two of the peak irrigation months and the increases are the result of releases from Lake McConaughy. April and May are the months of spring runoff and the North Platte River at North Platte shows a decrease in these flows following the construction of Lake McConaughy, which now holds back the higher flows.

The South Platte River at North Platte (fig. 45) had little change in the monthly mean flows. The records for the Platte River near Overton and Grand Island (figs. 46 and 47) do not indicate the large change that occurred in the North Platte River, but do show a small increase in the monthly mean flows during July and August. The change in monthly mean flows possibly is damped out by the South Platte River, which has had little change in the mean flows.

\section{Instantaneous Peak Flows}

The yearly instantaneous peak flows for six stations in the study reach are given in figures 48 through 53. The North Platte River at North Platte (fig. 48) indicates the largest change in peak flows of the six stations; this is most 1ikely a result of the on-stream construction of Kingsley Dam, which holds back the peak flows that once continued downstream. The statistical analysis (table 6) indicates again that a regression model of the logarithms of annual peak flow versus time needs to be divided into two models corresponding to pre-1935 and post-1935 time periods. This first model indicates a decrease in peak flows to 1935; following 1935 there is no significant change in the peak flows with time.

For the South Platte River near Kersey, Colorado, and the South Platte River at Julesburg, Colorado, the regression results indicate no shift in time series for the logarithms of peak flows as well as no significant trend with time. The F-test for the South Platte River at North Platte (fig. 51) indicates a homogeneity in the data set for the entire period, and there is a gradual decrease in annual peak flows throughout the entire period of record. The 1935 data point may have an inordinate effect on the trend of the regression.

The Platte River near Overton (fig. 52) indicates a single regression of the logarithms of annual peak flow versus time with a negative trend for the period of record, while statistically the 1935-present data set of peak flows at Grand Island (fig. 53) shows no appreciable trend. The similarity of the peak flows at Overton compared to the South Platte River near North Platte, shown by both statistical results and visual inspection, is indicative of the important contribution of the South Platte peak flows to 


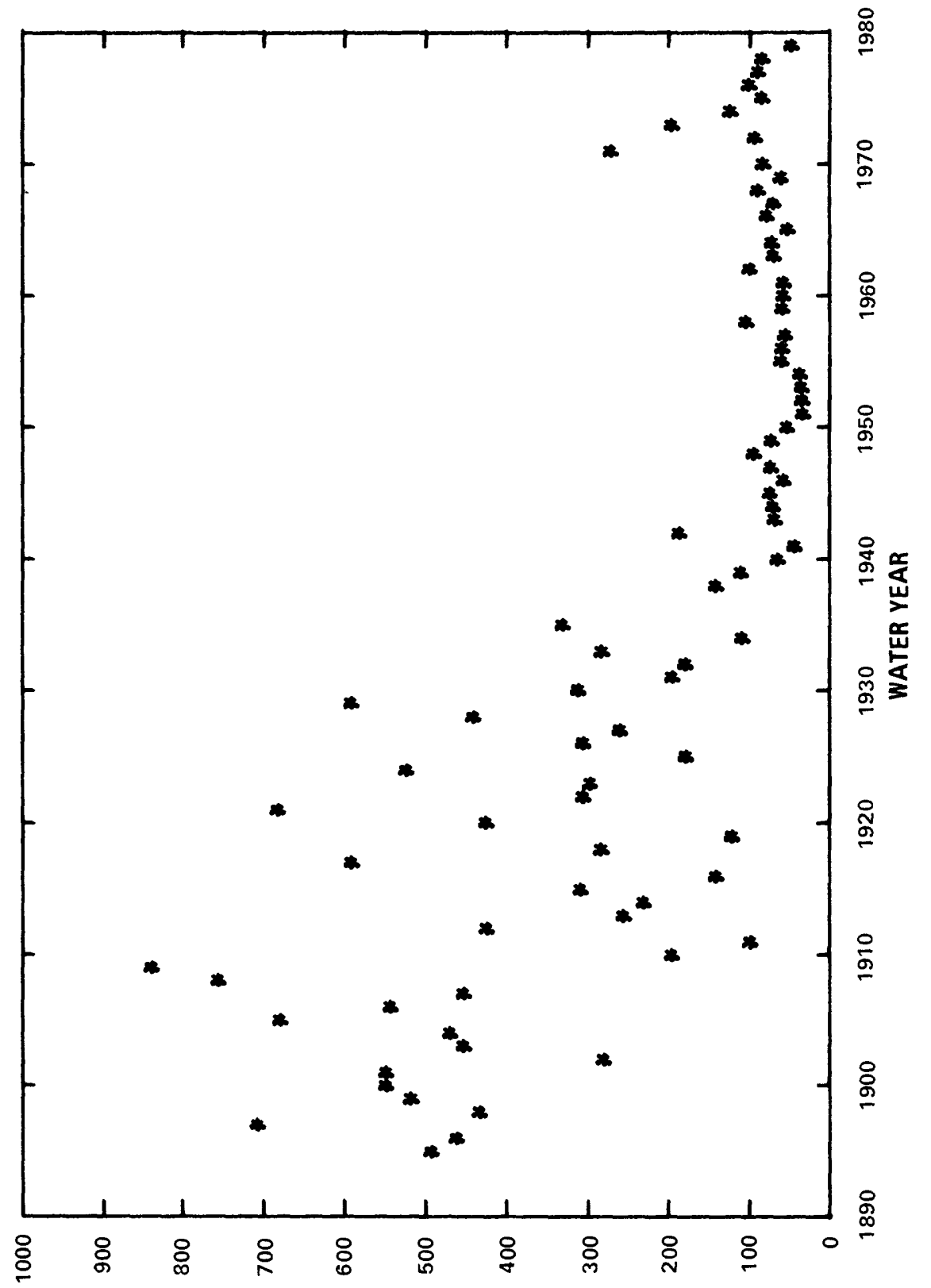

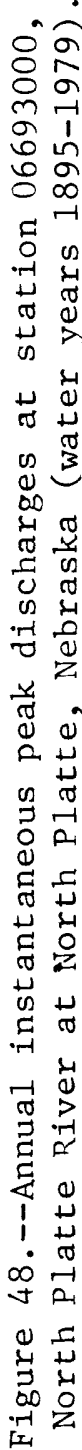

aNOJ y 


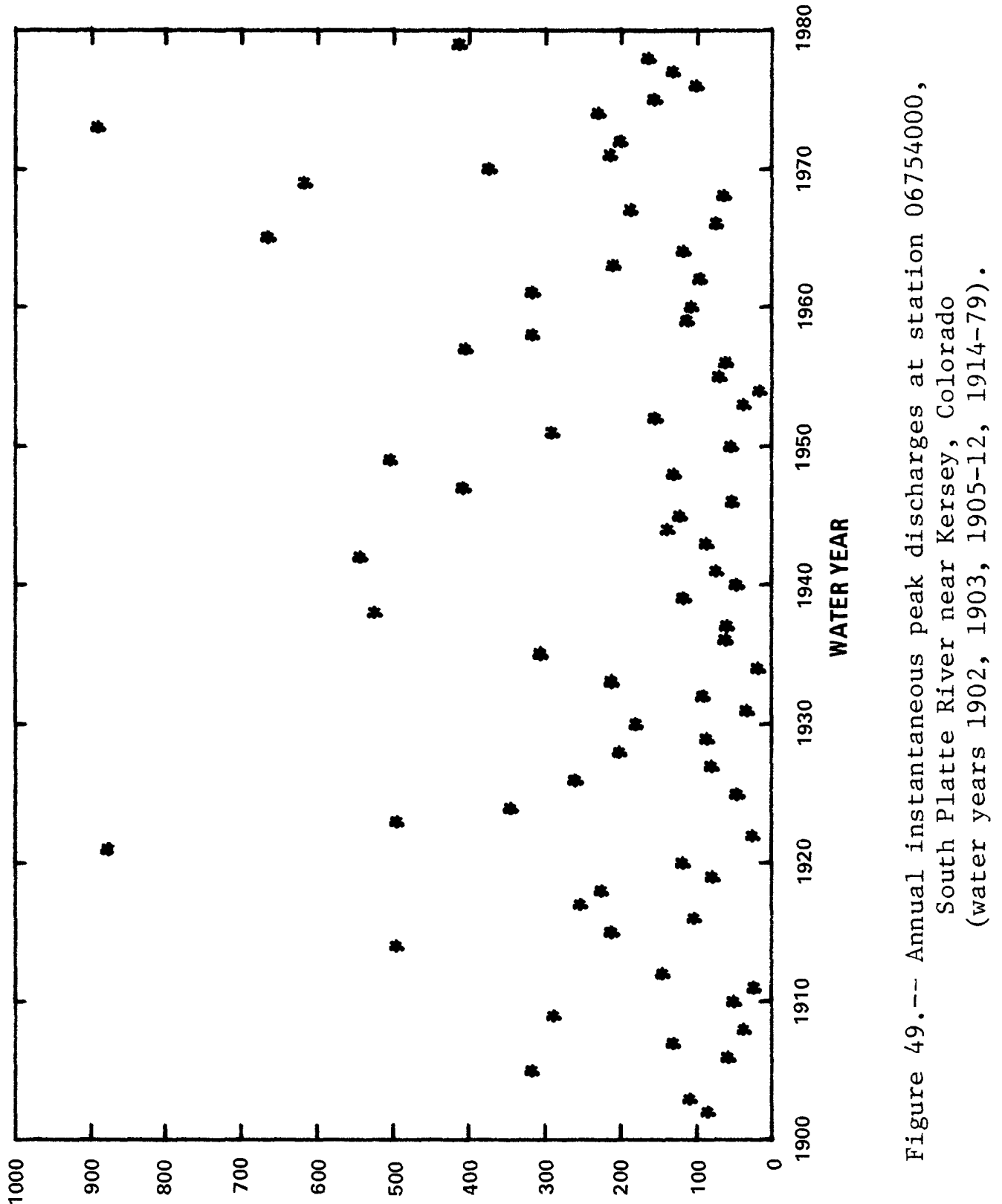

aNOJ y 


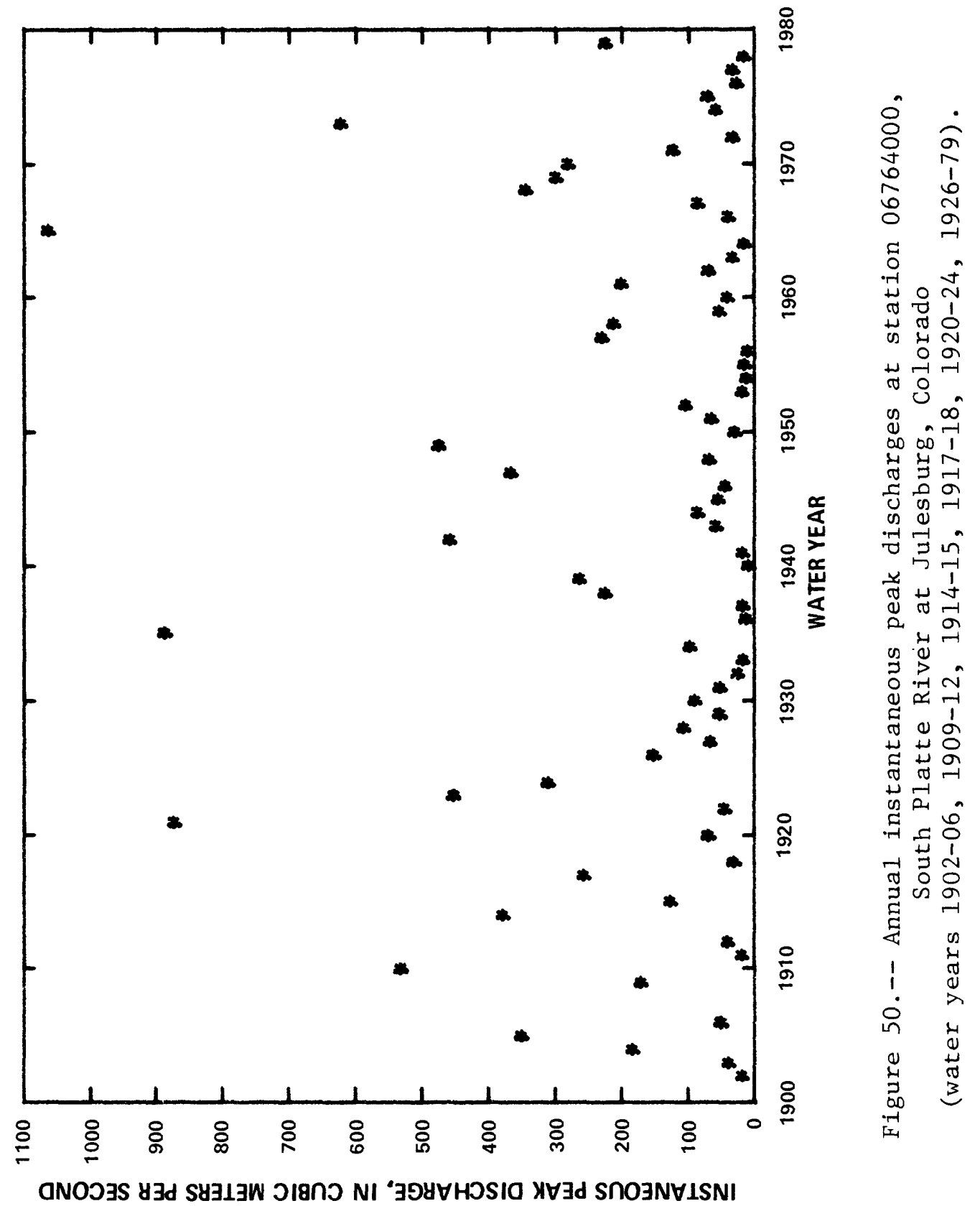




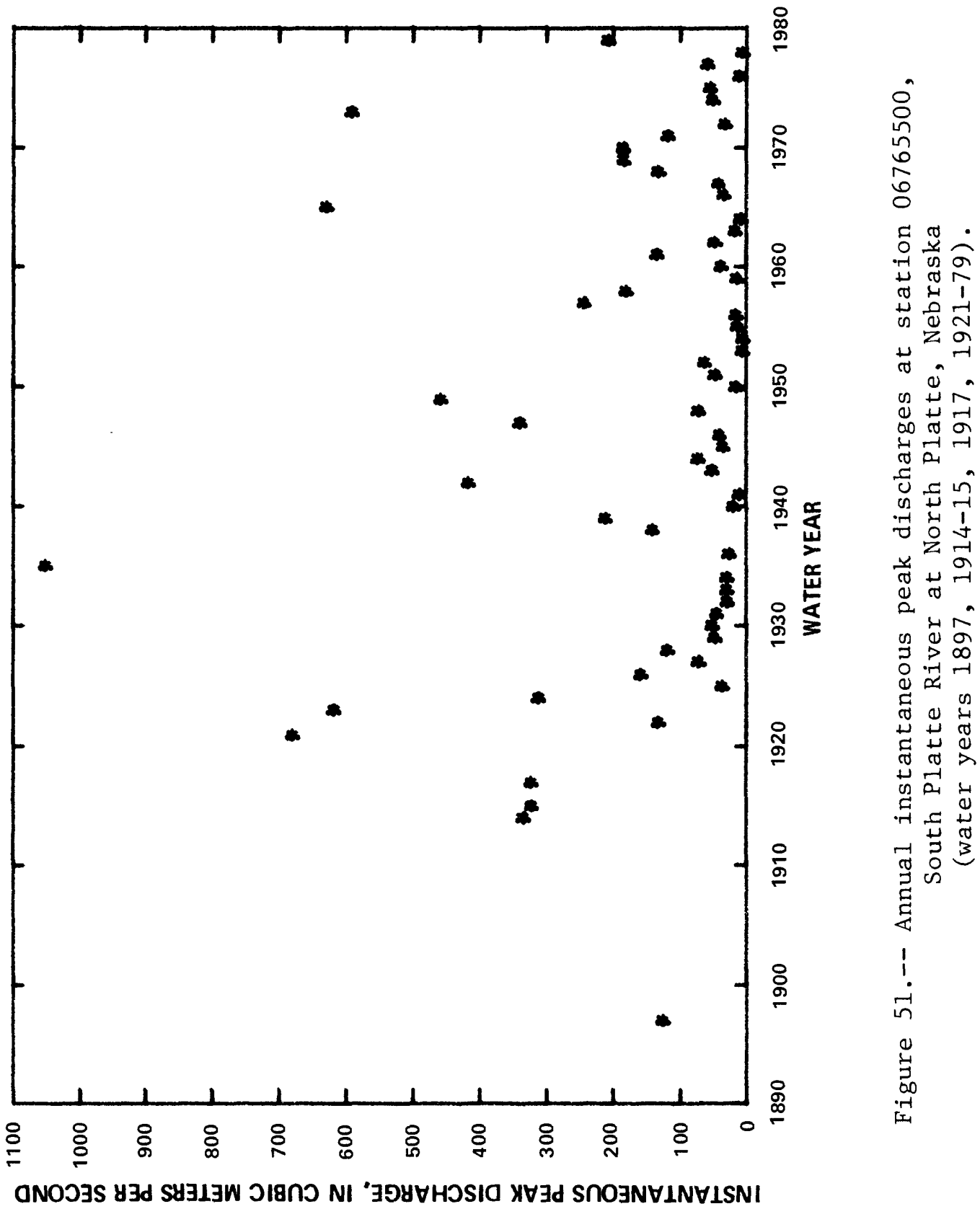




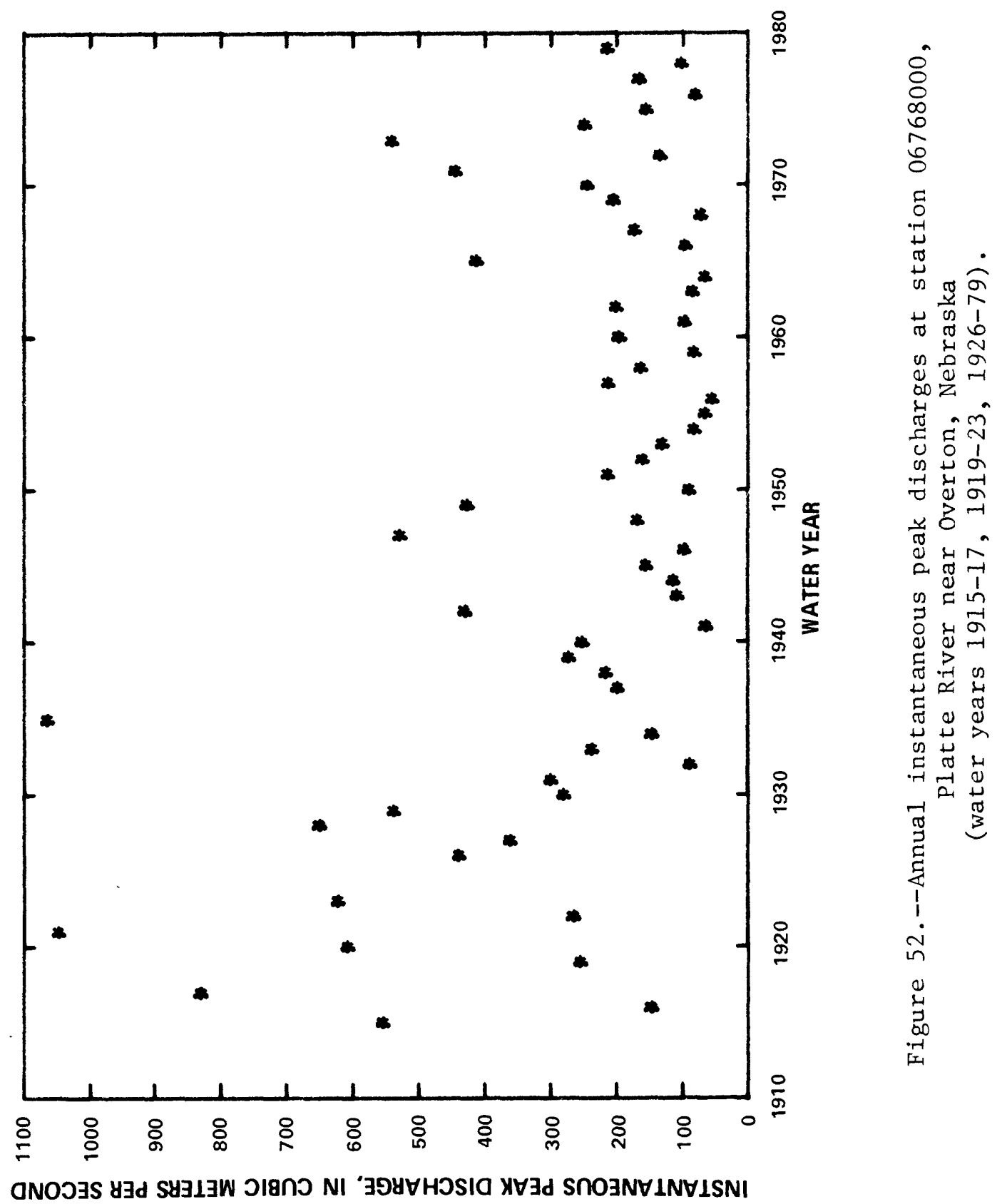




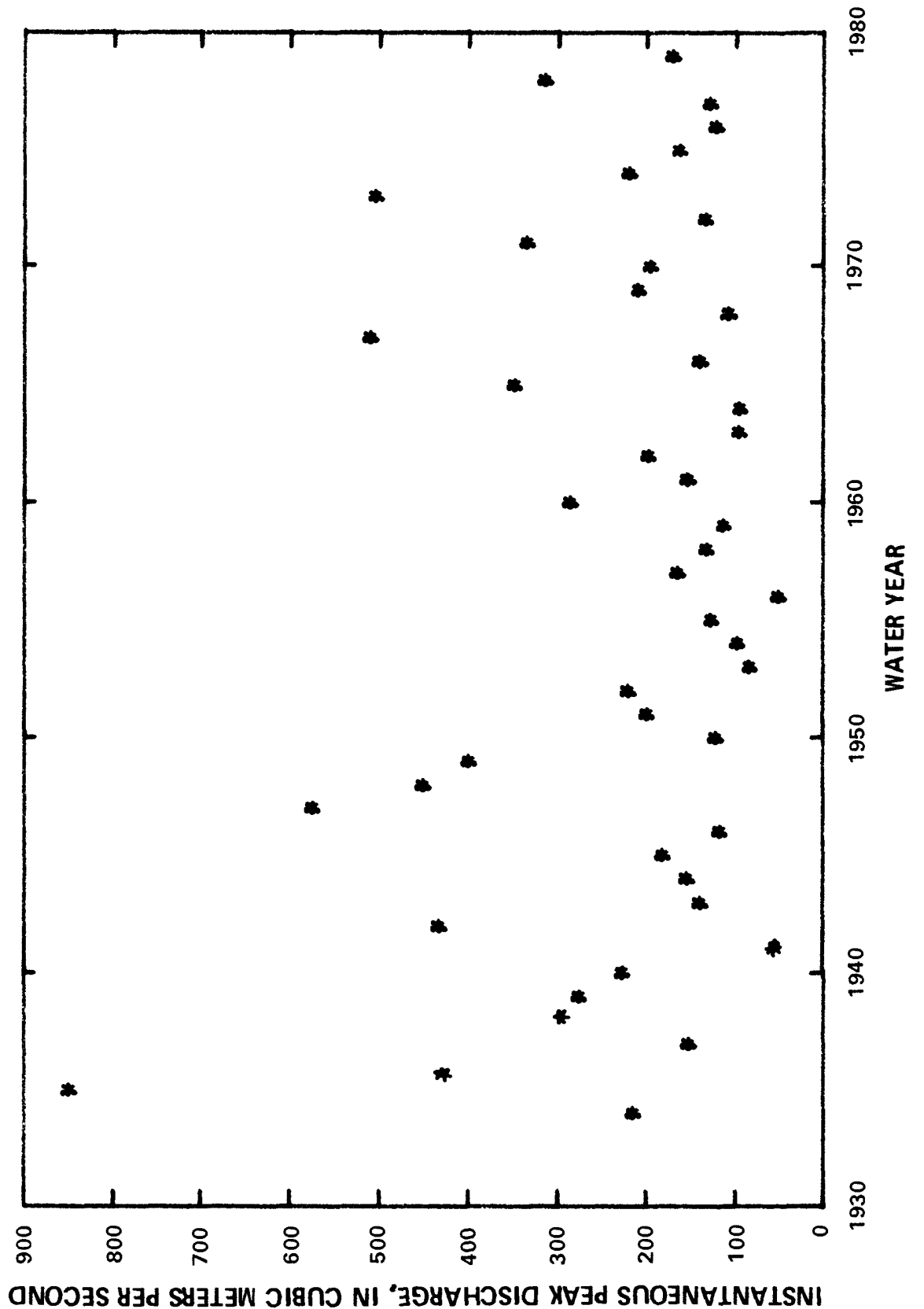

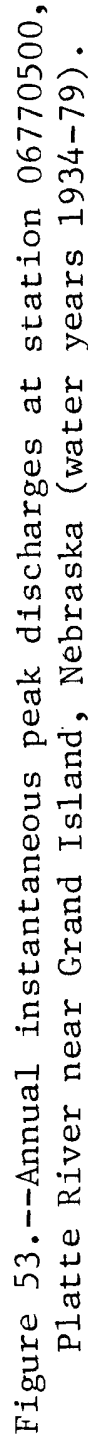

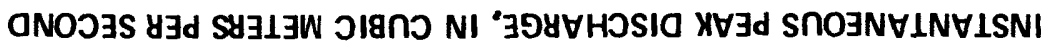




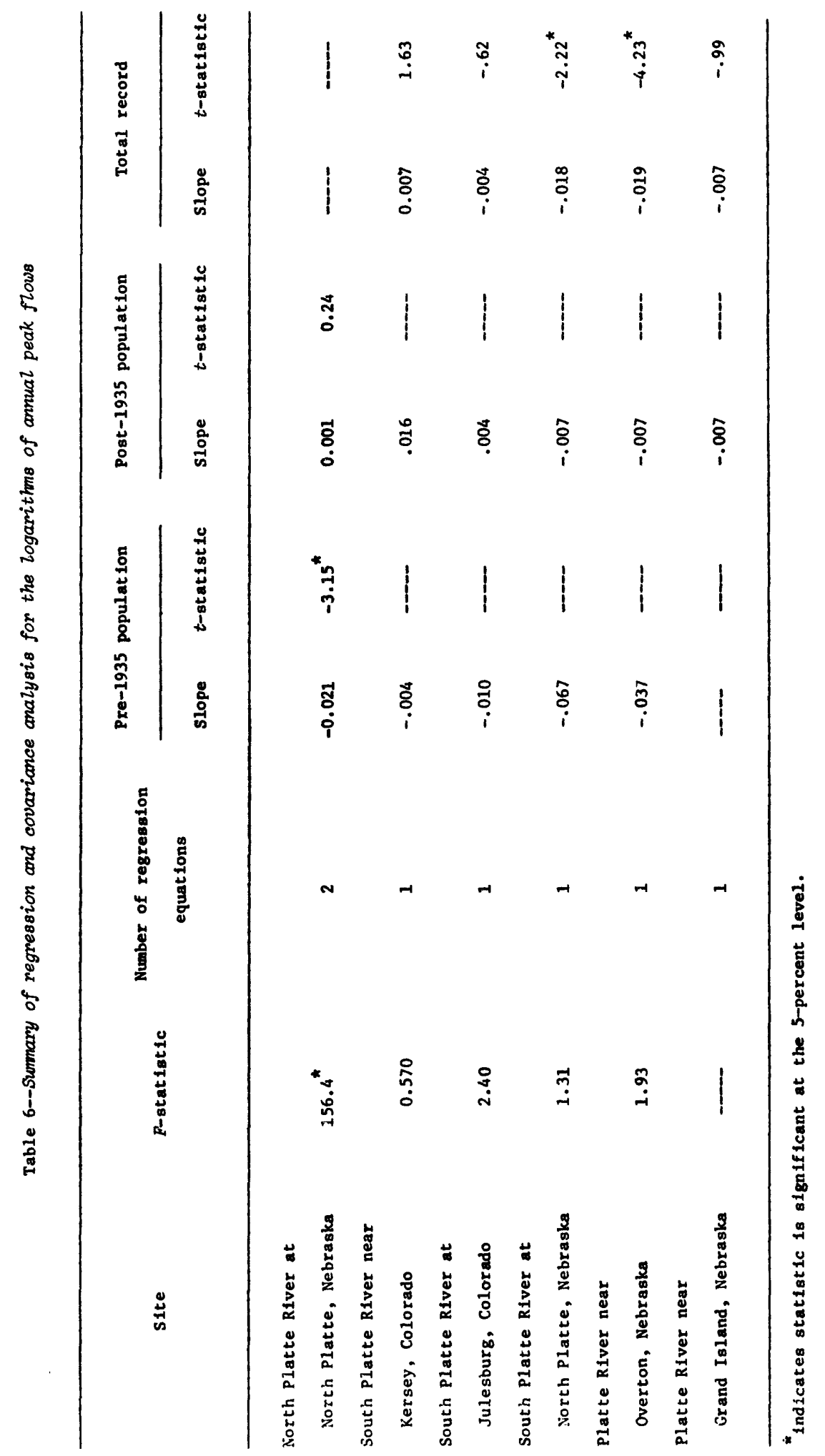


the Platte River major peak flows. The overlaid plots of peak flows for the South Platte River at North Platte, Nebraska, and the Platte River near Overton, Nebraska, are shown in figure 54. This is substantiated by Williams (1978) who stated that the North Platte River upstream from Lake McConaughy showed a decrease in peak flow after the construction of each of the major reservoirs in Wyoming, and the Platte River near Grand Island, Nebraska, shows similarity of peak-flow occurrences (fig. 54).

In order to illustrate the effect of the peak flows and mean flows of the South Platte and North Platte Rivers on the peak flows and mean flows for the Platte River near Overton, regression analyses were performed relating the logarithms of these flow variables, and the results are listed in table 7. Because the time-trend analyses previously discussed for both peak and mean flows of the North Platte River at North Platte indicate that two separate time periods need to be considered in making statistical determinations regarding this site, the interstation regressions were performed for each time period.

The difference in the magnitudes of the slope coefficients of the respective North Platte River and South Platte River flow variables are not legitimate measures of the relative importance of one independent variable compared to another in affecting the flow variables at Overton. This is true because the size of a coefficient would change as a result of merely changing the scale of the measurements of the variable. However, by adjusting the ordinary least-squares regression-slope coefficient estimates by the ratio of the standard deviations of the independent and dependent variables, an objective measure of importance of the independent variables can be determined. These adjusted coefficients are called "beta coefficients" (Goldberger, 1964). The beta coefficients calculated from the slope coefficients in table 7 are listed in table 8 .

The pre-1935 beta coefficients from table 8 indicate that the mean flow variable from the North Platte River at North Platte is the more important contributors to the mean flow variable at Overton. Similarly, the pre-1935 peak flow variable beta coefficients show the North Platte River peaks to be slightly more dominant than the peak flow variable from the South Platte River in affecting the peak flow variable at Overton. However, the post-1935 beta coefficient from the mean flow analysis indicate that the South Platte River has equalized its effect on the mean flow variable at Overton relative to the North Platte River's effect. The regression analysis of the post-1935 peak flow variable shows that the roles of the more important contributor for this flow variable have reversed. This role reversal can be explained by the fact that the South Platte peak flows account for the majority of the significant peaks at Overton. Although the North Platte River is a major contributor to most annual peak flows at Overton, most large peaks are derived from the South Platte basin. 


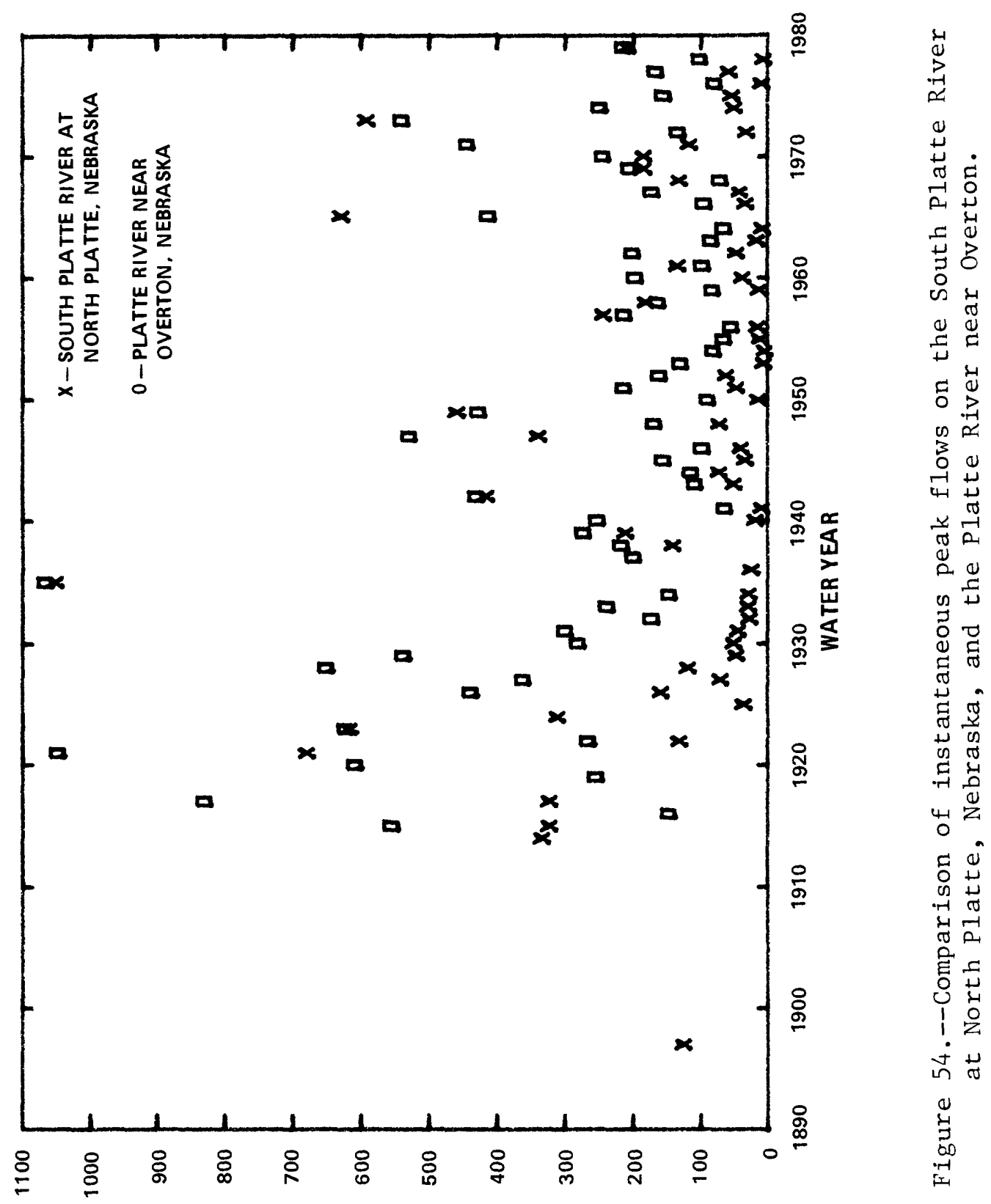

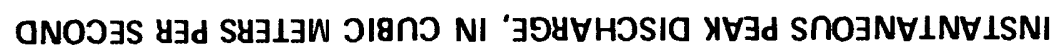




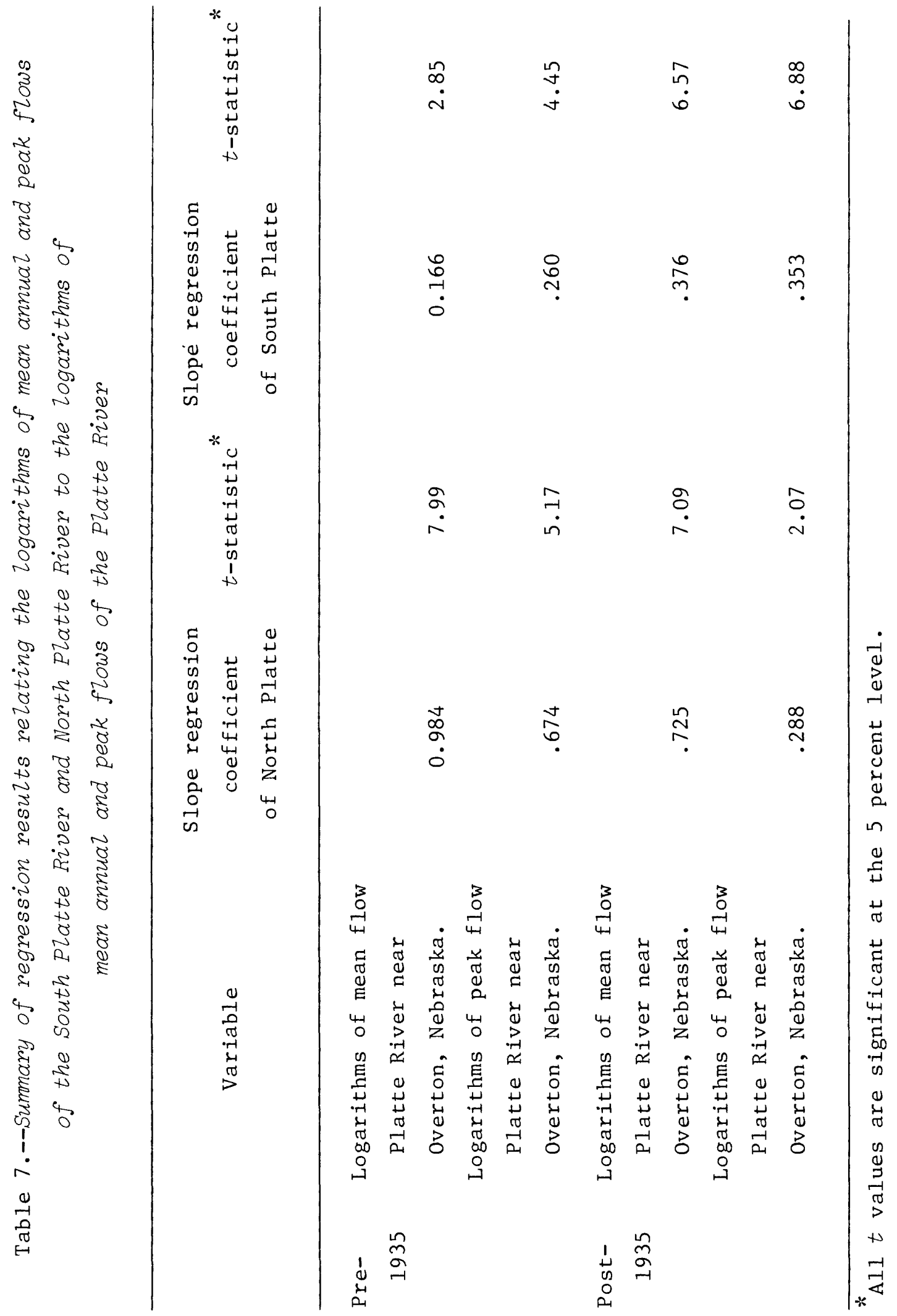


Table 8.--Summary of beta coefficients relating the logarithms of mean annual and peak flows of the North Platte River and South Platte River to the logarithms of mean annual and peak flows of the Platte River

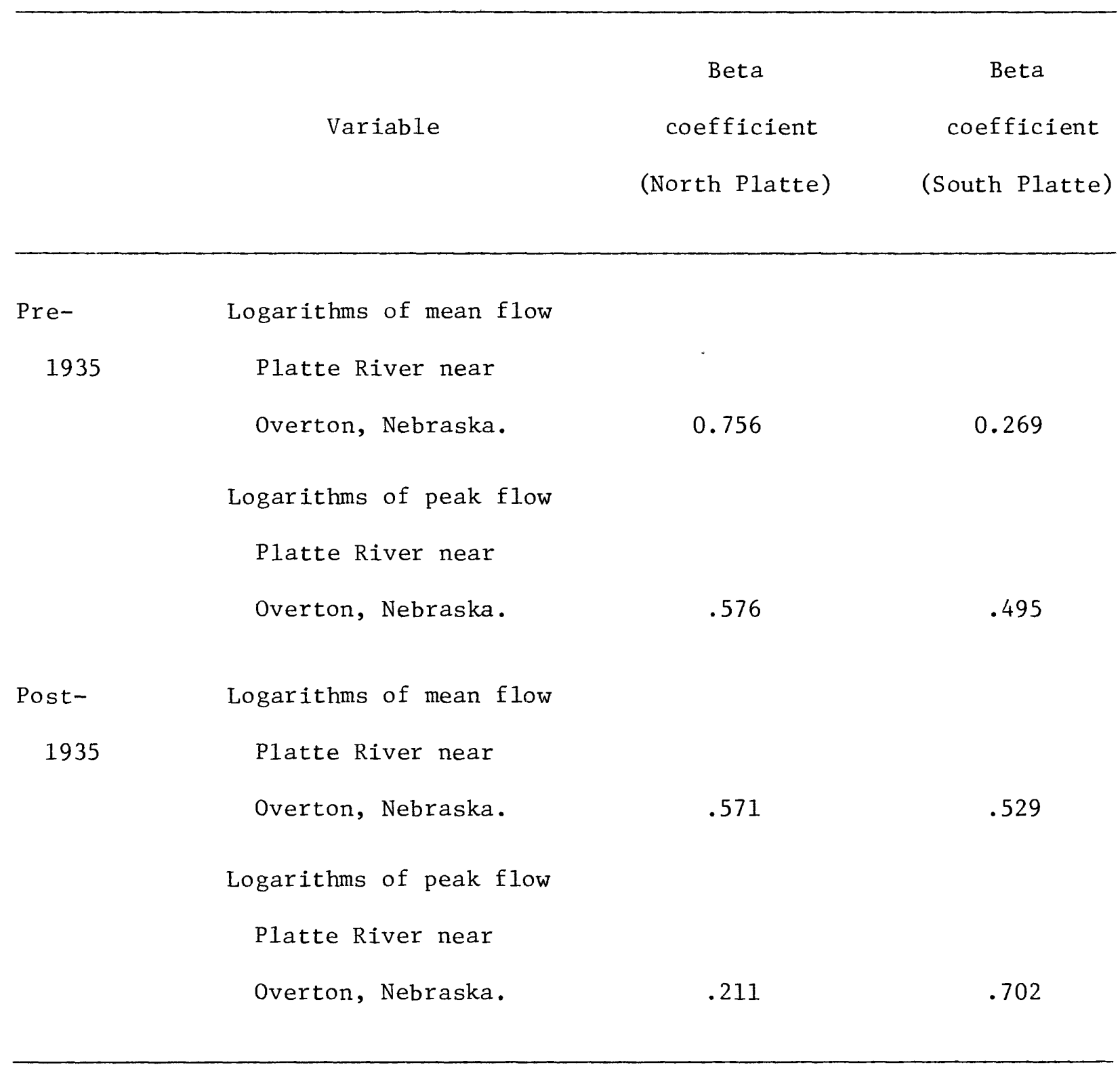




\section{SUMMARY}

Flow in the Platte River basin is affected by transmountain diversions in the headwaters, dams that create on-stream reservoirs, structures that divert water to off-stream reservoirs, ground-water pumpage from lands bordering rivers, return of water to channels from irrigation and hydropower releases, possible gain or loss of water by seepage, water demands of an increasing population, and the requirements of more vegetation that now grows in the river valley. These effects of man in the Platte River basin are the most logical explanation for the observed changes in flow.

Changes in surface-water hydrology and channel size have occurred at different times throughout the basin. The hydrologic changes are identified by shifts in levels of low flows and high flows, and the flattening of flow-duration curves. These changes also are illustrated in the time series of annual mean and peak flows. Changes in channel morphology are exhibited in the plots of width and area of the Platte River channels through time.

The hydrologic and channel changes have occurred in such a manner that the upstream reaches were affected earliest in the period of record. Observing the 10-year flow-duration curves and low flows at the sites studied indicate the stations upstream of the Platte River near Overton are maintaining relative stability, while those sites downstream of Overton still are adjusting to the changes in the hydrologic system upstream. This relative stability reached at each of the sites is as follows: The North Platte River at North Platte, Nebraska, about 1941; the South Platte River at Julesburg, Colorado, about 1920; the South Platte River at North Platte, Nebraska, about 1937; and the Platte River near Cozad and Overton, Nebraska, about 1950. The Platte River near Odessa, Grand Island, and Duncan, Nebraska, still is adjusting toward stability, while the South Platte River near Kersey, Colorado, has not shown any significant change for the period of record investigated. Therefore, in hydrologic analysis, caution needs to be taken in defining the period of record used because of the changing hydrologic system.

At each site, statistical analyses were performed on records prior to and following the construction of Kingsley Dam, to determine the effect on the peak and annual mean flows. The South Platte River in Colorado shows no trend in either the peak or annual mean flows. The South Platte River at North Platte, Nebraska, shows no trend in annual mean flows, but a decrease in peak flows for the period of record. The North Platte River at North Platte, Nebraska, and the Platte River near Overton, Nebraska, show a decrease in both the peak and annual mean flows, while the Platte River near Grand Island, Nebraska, shows no trend in the peak flows, but a slight increase in annual mean flows. 


\section{REFERENCES}

Bentall, Ray, 1975, Hydrology, Nebraska Mid-State Division and associated areas: Nebraska University Conservation and Survey Division, Institute of Agriculture and Natural Resources Report, 256 p.

Bental1, Ray, and Shaffer, F. B., 1975, Availability and use of water in Nebraska, 1975: Nebraska University Conservation and Survey Division, Institute of Agriculture and Natural Resources Report, no. 48, $121 \mathrm{p}$.

Currier, P. J., and Van Der Valk, A. G., 1980, The vegetation of the Platte River, in Phytosociology, forest development, and seedling establishment: U.S. Fish and Wildlife Service, Northern Prairie Wildlife Research Center, Jamestown, North Dakota, $40 \mathrm{p}$.

Gerlek, Steve, 1977, Water supply management analysis and alternative development for the South Platte River basin, v. 2: U.S. Army Corps of Engineers, $354 \mathrm{p}$.

Goldberger, A. S., 1964, Econometric theory: New York, John Wiley and Sons, $399 \mathrm{p}$.

Kleinbaum, D. G., and Kupper, L. L., 1978, Applied regression analyses and other multivariate methods: Belmont, California, Wadsworth Publishing, p. 209-226.

Meyers, J. S., 1962, Evaporation from the seventeen western States: U.S. Geological Survey Professional Paper 272-D, p. 71-100.

Riggs, H. C., 1969, Some statistical tools in hydrology: U.S. Geological Survey Techniques of Water-Resources Investigations, Book 4, Chapter Al, p. 34 . 1972, Low-flow investigations: U.S. Geological Survey Techniques of Water-Resources Investigations, Book 4, Chapter B1, p. 15.

Shaffer, F. B., 1976, History of irrigation and characteristics of streamflow in Nebraska part of the North and South Platte River basins: U.S. Geological Survey Open-File Report 76-167, 98 p.

Williams, G. P., 1978, The case of the shrinking channels-the North Platte and Platte Rivers in Nebraska: U.S. Geological Survey Circular 781, $48 \mathrm{p}$. 